\title{
S־T NICOTINE
}

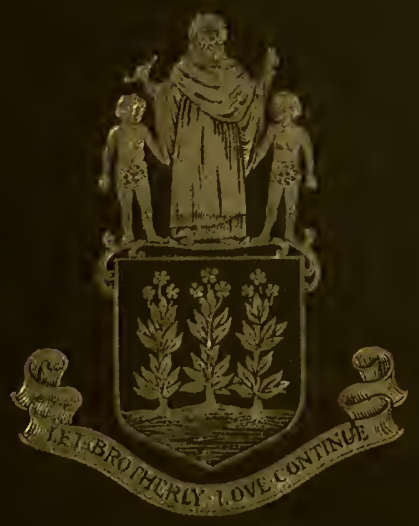

E-V.HEWARD 
<smiles>[C+]1=CC=C1</smiles> 
0.9

$O A$ 
Digitized by the Internet Archive in 2007 with funding from Microsoft Corporation 



\section{ST NICOTINE}

$$
\text { OR }
$$

THE PEACE PIPE 

- 

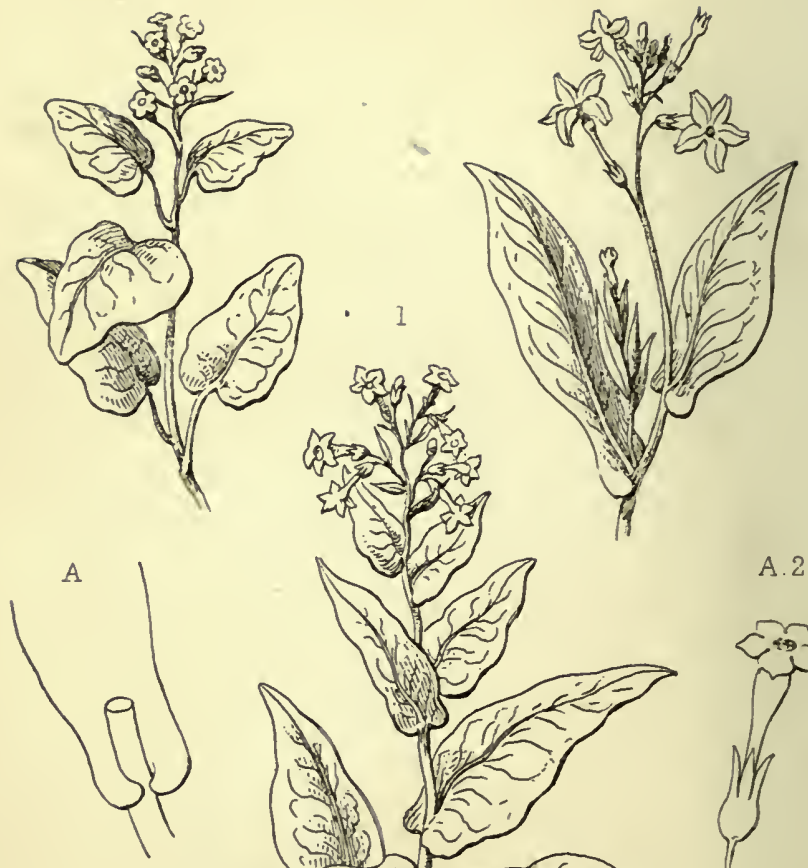

A. 2

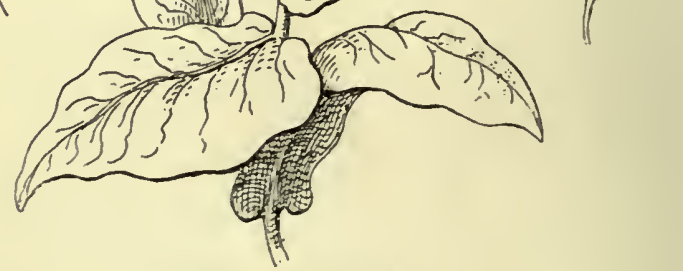

Inam \&e Engrared by $I$ W Partilt

TOBacco PLANTS.

1. Nicotiana Tabacum; 2. N. Rustica; 3. N. Persica.

[By permission of Messrs. Chapman \& Hall, Ld. 


\title{
ST NICOTINE OF
}

THE PEACE PIPE

\author{
BY \\ EDWARD VINCENT HEWARD
}

WITH 4 FULL PAGE PLATES AND 5 TEXT CUTS

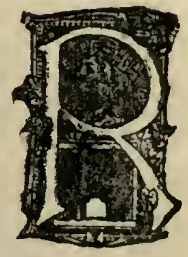

\section{LONDON}

GEORGE ROUTLEDGE \& SONS, LTD.

NEW YORK: E. P. DutTon \& CO. 



\section{INTRODUCTORY}

THE history and associations of tobacco carry the thoughts back to the jubilant days when Good Queen Bess was the idol of her people, to the stirring times when bounding gaiety and lusty banter found expression in unrestrained mirth as readily in the open street as within doors. The writer's aim in the following chapters has been to bring together (in a somewhat desultory way, it may be) the chief features of interest which the story of the 'Indian's herb' presents to us to-day. The social element undoubtedly dominates all others; this, coupled with the primitive belief in its medicinal properties, at once secured for it the good-will of men longing for knowledge of the New World and ever ready to adopt an indulgence so alluring. That this feeling was universal is shewn by the rapidity with which the smoking habit spread over the Earth wherever there was a human habitation. No less remarkable is the sturdy tenacity with which men everywhere stuck to it despite the determined opposition of potentates and pontiffs.

In the eyes of her votaries St Nicotine's virtues are rare and manifold. Indeed all sorts of pretty things have been said and sung in her praise, and as becomes a faithful devotee at her shrine the writer believes them all as implicitly-well, as a child believes fairy tales. Many a nonsmoker when questioned about his indifference to her gracious influence has heaved a pensive sigh and lamented Dame Nature's ill-usage in den ying him the taste for the nicotian incense. Consolation comes not to him when told that the good genius has knit together a brotherhood who, regaled with her balmy breath, realize the touch of nature which makes the whole world kin; that on her approach petty vexations vanish into space, and fancy, untrammelled, roves in Parnassian bowers, or sees in the vapour rising from the bowl nebulous forms resembling those in the far-off starry sky. 
The demon of insomnia flies from her presence, and upon the sleepless she breathes 'tired nature's sweet restorer.' Faith born of experience bears willing testimony to this priceless virtue. Once upon a time, too remote to recall the year, it befell the writer of these lines to suffer from the effects of insomnia. Wakeful nights followed by comatose days passed into months, and the relief the poet Young had wooed in rain still held aloof. At last fortune smiled. Walking with a friend one evening a cigar was proffered him. Not being a smoker he declined the weed. Again urged to try it (without any suggestion of its narcotic properties) he did so and smoked it to the end. That night he fell into a sleep so profound that on waking the next morning the hours that had fled seemed but as a moment. Years have rolled by since then, but not an evening has passed unsolaced by the gentle anodyne.

Opponents of tobacco-smoking generally base their objection on the rather shaky ground of what they with emphasis term, 'principle.' A case of the kind cropped up a few years ago when Professor Huxley related the story of how he had become a convert to the creed of the tobacconist. It runs as follows :-

'When I was a young man I went with a party of my friends to Holland. It happened that they were smokers and I was not. I did my best to fortify myself in determined resistance to the pernicious habit, which from my standpoint I looked upon as wholly indefensible. The tobacco plant belongs to a family of poisoners-certainly a poisonous family, what then could be said in its favour? Science and reason being opposed to it how could intelligent beings submit to its sway, and with so much assumed pleasure? Thus I mused with my back propped against the hotel wall where in a cosy room inside my friends were quietly enjoying themselves with their weeds and social gossip. I fought with myself. I fought against the seductive influence of the goddess, and failed. The flesh was too strong for philosophy: I crept in and joined them with my first cigar.'

A lady once confessed to the writer that she had all unwittingly followed in the wake of a smoker whose cigar 
shed on the air a fragrance so delicate that for a time it was quite irresistible. Doubtless many another could, if so minded tell of a similar experience. A good cigar indeed - Havana or Cuban leaf for preference-is an inspiration. A meerschaum pipe when 'mellow, rich and ripe' is a treasure; but cigarettes are becoming, if they have not already become, a nuisance.

Grateful memories of the weed are enshrined in the literature of every language; and many an old and odd volume have yielded to the gleaner the materials of which the following pages are made up. Some parts have already seen the light in the form of magazine articles, and for permission to republish these the writer tenders his thanks to Sir James Knowles, of the Nineteenth Century Review, to the Editor of Macmillan's Magazine, and to Sylvanus Urban of the Gentleman's Magazine.

And this may be the fitting place to acknowledge the courtesy and kindness of the principal (Mr. A. C. Wood) of the Statistical Office of H.M. Customs, who has furnished the tabular statement, which appears below, shewing the latest facts and figures on importations of tobacco, on the rate of consumption per head of population in the United Kingdom, and the revenue derived therefrom.

Statistical Office,

H.M. Customs.

Since the date of your article there have been some considerable changes in the fiscal position of Tobacco and the following are the chief changes in rates of duty per lb. since 1898 :--

Unmanufactured

Tubacco.

1898

1904

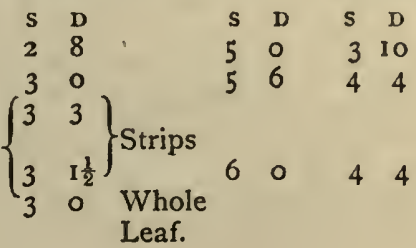

Other

Sorts.

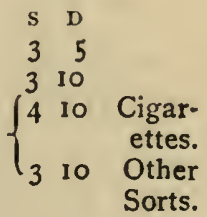


The maximum limit of moisture allowed in manufacture of Tobacco was fixed in 1887 at 35 per cent., and was changed in 1898 to 30 per cent., and again raised in 1904 to 32 per cent.

The moisture naturally present in the kinds of Tobacco now imported averages about 14 per cent. I mention these facts because they are as you know of considerable importance in making calculations of the quantities sold over the counters of retailers to consumers.

Perhaps I may add that in 1904 differential rates were levied on Stripped or Stemmed Tobacco, that is upon Leaf from which the 'midrib' had been removed. 'The duty on 'strips' imported before the Budget was fixed at 3 s. I $\frac{1}{2} \mathrm{~d}$. the lb., and at 3 s. $3 \mathrm{~d}$. on Strips brought here afterwards, while the duty on whole leaf Tobacco was settled at 35. od. the lb.

\section{I am, Sir,}

Your obedient servant,

A. C. WOOD,

E. V. HEWARD, ESQ.

Principal.

\section{UNITED KINGDOM}

Tobacco. Financial Year 1904-5

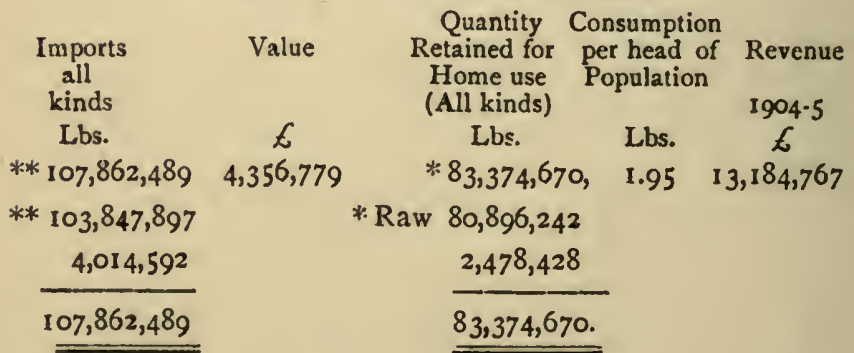




\section{CONTENTS}

\section{INTRODUCTORY}

AN ndulgence which promotes sociality, mirth, and day. dreams-Men hold to the weed regardless of opposition-St Nicotine's manifold virtues-The non-smoker's incapacity for enjoyment of smoking - Brings sleep to the sleepless-Opponents base their objection on principleProf. Huxley's experience-Havana cigar the ideal smoke-Acknowledgments to Editors and H.M. Customs.

\section{A SYMPOSIUM}

\section{CHAPTER
PART I}

TOBACCo smoking thought much of in Elizabeth's reignDrawing the smoke into the lungs and ejecting it through the nostrils provokes hilarity in the city-Sir John Beaumont's Metamorphosis of Tobacco-Conceives the idea of a Parliament of the immortals to determine upon the composition of tobacco-Drayton on Beaumont's early death-Jupiter calls a council to consider the odic essence which has calmed his anger-England's great smokers from Raleigh to Dr. Parr give an account of their experiences. 
SYMPOSIUM

\section{CHAPTER
PART II}

CARLYLE, as a persistent preacher of the gospel of silence with his pipe-Frederick the Great's Tobacco ParliamentCarlyle's early experience in smoking and his first pinch of snuff-Charles Lamb and his associates over the pipeBismarck's Bund story-Divergent French views on the use of tobacco-Robert Hall, Spurgeon, Capt. Marryat, Fairholt, Inglis, Thackeray, and Bulwer Lytton, all express opinions favourable to tobacco smoking.

\section{CHAPTER III}

\section{THE HOME OF THE INDIAN WEED}

Columbus secures Queen Isabel's good-will and help-Overcomes all difficulties and sets sail in three small vessels from Palos on his great enterprise westward-Mutiny suppressed-San Salvador reached after three months' toil-The officers land-Natives friendly-Two captured and brought on board the Santa Maria-A gladsome sight meets their eyes-Cuba reached; the most beautiful island ever beheld-Clothed with perennial verdureTwo of the crew sent to explore-Natives discovered smoking fire-brands-They conceive a passion for smoking-Columbus collects rarities to take with him to Spain-Reports to the king and his consort the achievement of his project-Is received with honour and made high admiral of a new and powerful fleet with which he returns to the West Indies-Gonzalo Oviedo, Inspector-general of the newly discovered country-Fra Ramono Pane sends Peter Martyr the first written account of tobacco and native method of using it-Snuff-taking in France-The origin of the name tobacco-Red Indian's use of the weed-Oviedo dislikes tobacco-The dis. 


\section{CONTENTS}

\section{of $1 \sim^{*}$}

covery of South America-The "Aztecs of MexicoThe Italian traveller Benzoni describes the plant and its uses-among the natires-His strong aversion to it-The origin of the plant related by the chief of the Susquehanna tribe

CHAPTER IV . . .

TOBACCO IN RELATION TO HEALTH

\section{AND CHARACTER}

Tye Chancellor of the Exchequer on the consumption of tobacco-His condemnation of the smoking habit by those who have enough to eat-Board of Trade returnsStatistics on the past and present rate of consumption per head of population in England and other countriesThe quantity of tobacco consumed compared with the average consumption of wheat and the money value of each-The use made of cast-away cigar-ends-The opinions of Michael Drayton and Robert Burton-Case against youths smoking-The Cuban leaf-The effects of smoking on the character of the Turks-Mr. E. W. Lane on the Oriental method of smoking-Clarendon's views on tobacco's influence in diplomacy-The three kinds of tobacco used in commerce-Botanical description-The chemist's account of the composition of the weed -Shakespeare's 'hebenon'-Sir B. W. Richardson's experiments with the smoke of tobacco-Tobacco innoxious compared with alcohol-Prof. Johnston's experimonts and observations-Observed effects on German thinkers-Pre-eminent among great smokers stand Hobbes, Newton, Parr, Aldrich, Hall, Carlyle and Tennyson-Experience the true guide.

$$
\text { CHAPTER V . . . }
$$

THE USE AND ABUSE OF TOBACCO

DIFFERBNCES of temperament interfere with general enjoyment of the weed-Ground apon which all can agree-Its 
germicidal action demonstrated in laboratory experiments-Faith of our forefathers in tobacco's all-healing properties-Particularly as a destroyer of insect life on plants and animals-Liebault's account of Nicot's introduction of tobacco into France and experiments on old sores and wounds-Fame of throughout Portugal, France-Catherine de Medici plants seeds of in her garden-George Buchanan's distrust of anything which bears her name-Italy's first instalment of the weed received from Spain-Spenser in the Faërie Queene speaks of 'divine tobacco'-William Lyly calls it the 'holy herb nicotian'-Henry Buttes on tobacco as a dietetic-Dr. Gardiner describes its use in medicineHarleian Miscellany on tobacco-Dr. Thorius's Hymnus Tabac-Pepys' experience with tobacco-Dr. Willis on its prophylactic effects in the plague of 1666-Dr. Diemerbroech finds it kills contagion during plague in Holland 1635-6-Coleridge in Cologne-Medical profession's changed attitude towards tobacco-Mr. Solly, of St. Thomas's Hospital, proclaims a crusade against smoking-Dr. Murray at a later date speaks highly in its favour from army experience-Private McCarthy's quiet pipe in the hospital yard-Soldiers' experiences in South Africa-Government's changing practices in regard to contraband tobacco-Soldiers sent out in troop-ships have first claim.

\section{CHAPTER VI}

\section{ON THE ANTIQUITY OF TOBACCO-SMOXING}

Tuk beginnings of history-Ancestor worship-Man's instinctive craving for narcotics and stimulants-Ancient historic allusions to smoking or burning of vegetable substancesLieut. Walpole's account of an Arabic MS. which came into his hands at Mosul-Nimrod a tobacco-smokerAssyrian cylinders in the British Museum-Noah a smoker, a Greek Church tradition-The Moslem sage and the origin of the tobacco plant-Eulia Effendi's story of a tobacco pipe found in an old wall-Tobacco un. 
known in Turkey before 1610-Dr. Yates mistakes an Egyptian painting representing glass-blowers for a smoking party-Both Greeks and Romans inhaled fumes of tussilago through a reed or pipe for the cure of coughs and difficult breathing-Abbé Cocket and Dr. Bruce on old clay pipes found in Normandy and among ruins in BritainClay pipes found in Scotland and Ireland-Legendary lore respecting their origin and use-The weed and the Portuguese in India and Java-Pallas and Meyen on the plant in India and China-The Lazarists, Gabet and Huc, in Tartary and Thibet-The cultivation and use of tobacco in China-The supposed antiquity of the habit among the Chinese, who in their prehistoric migrations may have carried seeds of the plant to America.

\section{CHAPTER VII . . .}

\section{A GLIMPSE OF SOCIAL LIFE IN JAPAN.}

\section{AS DISCLOSED BY THE WEED}

ThE Japanese-Marco Polo's mention of Japan and its peoplePinto, Portugal's pioneer in eastern seas-Lands at Nagasaki in 1545-Friendly reception-News of the event reaches Manila and Goa-Spanish merchant vessels with Francis Xavier speedily arrived at Bungo-Warm welcome-Tobacco and smoking, a new revelation to these primitive people-Good work done by Xavier and his coadjutors among the sick and needy-The Shogun, Iyeyasu, permits free intercourse and unrestricted tradeSpaniards and Portuguese accused of overreaching practices, and of draining the country of its gold-Jesuits and Friars swarm in Japan and bring upon themselves disgrace and ultimate expulsion-William Adams the first Englishman to set foot in Japan-His rapid rise in favour and fortune-The arrival of Dutch merchantmen-Helped by Adams to secure a trade basis at Firando-Adams desires to return home, but is put off from time to timeHe writes letters to England telling of himself, and inviting London merchants to trade with Japan-They 
do so, and ressels laden with merchandise are despatched under the command of Captain Saris, who bears a letter from King James to the Emperor of Japan, resulting in England's first commercial treaty with that countryAdams dies in Japan after twenty years' residence, loved and honoured by all.

An Edict against smoking falls into abeyance-Family records of smoking in 1605-7-Excellent properties of tobacco-smoking enumerated by an old writer-Objections to its use-The theft of the golden pipeSmoking now universal in Japan-An 'At Home'Men's revolt against women's authority as to when and where to smoke-Primitive habits among the peasantryCultivation and revenue-Sir Earnest Satow statisticsReflections.

\section{CHAPTER VIII}

\section{STRAY LEAVES FROM THE INDIAN WEED}

The late Poet Laureate's (Tennyson) love of tobaccosmoking-Science detects poisonous elements in the exotic-The philosophy of smoking-The only thing in life that fumes without fretting and assuages the fretful -The bachelor's love of seclusion with his pipeNapoleon's first and last attempt at smoking-A distraught youth and an Oriental sage, an eastern view of the virtue of the weed-Raleigh and the New World - His expedition to explore the coast of the El Dorado and win renown for England and his idolized Queen Bess-England's first smokers-Hawkins, not Raleigh, the first to bring tobacco to this country-Raleigh and Queen Elizabeth-The wager as to the weight of the smoke exhaled from a pipeful of tobacco-King James's 'Counterblaste to Tobacco'-Its home cultivation and manufacture-Ben Jonson's 'Alchemist '- 'Bartholomew Faire'-Dr. Barclay on sophistication of tobacco-Old Rome smoked coltsfoot and leaves of the lettuce-Paper warfare over the virtues or vices of the Indian weed 
- Joshua Sylvester sends a 'volley of holy shot' against the 'idolatrous weed'-Samuel Rowland's 'Knave of Clubbs,' a humorous satire on tobacco-smoking-Eastern potentates' treatment of smokers of the Frankish novelty -Russian atrocities inflicted on users of the weedForeign Governments begin to see in it an easy means of augmenting revenue-Peter the Great invites English tobacco merchants to Moscow in order to establish a factory there for the manufacture of tobacco-Queen Anne in Council disapproves of the scheme, and orders our Envoy to destroy the works and return the workmen to their homes.

\section{CHAPTER IX . . . 169}

\section{SOCIAL GOSSIP ABOUT THE WEED}

GeORGE WitueR's song on tobacco-smoking-Undergoes numerous alterations by later writers-Mr. Chappell, through Mr. Payne Collier, traces the original song to Wither-Bishop Fletcher succumbs to over-indulgence in the pipe-Rev. W. Bredon resorts to the hemp cut off the ends of the church bell-ropes as a substitute for tobacco--Raleigh carries the novelty to Court and makes smoking popular-Merriment in the city over the 'tobacconists '-Ben Jonson's mention of smoking'Every Man out of his Humour'-'The Gipsies Metamorphosed '- Bartholomew Faire'-Dekker's 'Gull's Horn Book'-His 'Satiromastix'-Women smokersThe daughters of Louis XIV. smoke in their private apartments-England's paper warfare over the merits or demerits of the weed-Joshua Sylvester supports the King's 'Counterblaste '-Heavy duty on tobacco and its ruinous cost to the consumer-Peter Campbell's willSir Edwin Sandys on the sum paid for tobacco received from Spain-Dr. Everard on the 'Wonderful Vertues of Tobacco taken in a Pipe'-Dr. Barclay's NepenthesDe Rochefort tells of smoking in rural EnglandMentions the case of a Spaniard using a bit of the cable 
end in lien of tohacco-Of smoking in bed-Mission's remarks about the effects of tobaeco on Englishmen-His verses in praise of smoking-Dr. Aldrich, Dean of Christchurch, Oxford-His song on tobacco, to be smoked while singing-His higher claims to admiration.

\section{CHAPTER X $\quad \cdot \quad \cdot 184$}

\section{THE TOBACCO INDUSTRY AND SMOXING PIPES}

VARIOUs kinds and sources of supply-Qualities due to climate, soil or other causes-Natural qualites determine destination-Strong kinds find favour in North America, mild in Europe-Cuba's leaf richest in excellences desired by smokers-Cuba's make-up the model for the rest of the tobacco producing world-The effect of the McKinley tariff on Cuban cigar manufacture-The highly prized and priced Havana legitimas-Small area over which the Havana plant is grown-Harvesting and curing operations in Florida-Packing of bales for exportation--Bonded warehousing accommodation and its regulations-Different kinds of cigars suited to different seasons and climatesManila cheroots, their kinds and manufacture-Government monopoly and its removal-Illicit growth of the plant by mountaincers-Number of employés, their work and wages-Cheroots used in lieu of coin-Various kinds of tobacco offered to the consumer-Invisible life infests tobacco leaves-Tobacco culture prohibited in England except in Physic Gardens-Removed in I886-Failure of English cultivation-Manufacture of eigars-Inequality of Customs duty-Historical view of tobacco pipesClay piyes-Meerschaum, its origin and manufactureBriar-root and other materials used for pipes. 


\section{LIST OF ILLUSTRATIONS}

tomacco Plant . . . . frontispiece

SiR Walter RALEigh . . . . . " " 6

DEPARTURE OF COLUNBUS (from a rare old painter) „ 22

QUEEN ELIZABETH • • • • • • " " 132

A ChINesh PIPE . . . . . . . II2

INDIAN PIPE-Heads found in Mound City, Ohio . 113

A Japanese PIPE

DUC DE SUlly . . . . . . . . . 153

EARLy SEVENTEENTH-CENTURY SMOKERS • • 173 



\section{ST NICOTINE}

\section{SYMPOSIUM}

\section{CHAPTER I}

\section{PART I}

Let me adore with my thrice happy pen The sweet and sole delight of mortal men; The cornucopia of all earthly pleasure, Where bankrupt nature hath consumed her treasure ; A worthy plant springing from Flora's hand, The blessed offspring of an uncouth land.

BEAUMONT.

IN the early days of her advent in these isles St Nicotine stood high in the land. For she had come bearing credentials from France and Portugal testifying to her many. virtues as a healer of the sick as well as a social comfort. And sober-minded folk would sit outside their doors, pipe in hand, placidly inhaling the grateful vapour of the precious herb a kind Providence had sent them to assuage the ills flesh is heir to. But the quick eye and ready wit of the city wags saw the matter in a different light. The Spanish fashion of smoking, namely, of drawing the smoke into the lungs and ejecting it through 'the organs of the nose,' afforded them endless amusement, and sportive jests were 
heard on all sides about the men who made chimneys of their noses. The important part the exotic played in life's comedy led the youthful aspirant to literary fame, Sir John Beaumont, to think that he could not do better than soar on the wings of the weed to the Parnassus he had already in view. Barely twenty, full of exuberance and lofty ideals, he poured forth his musings in a grand imitation of heroic verse. His work is entitted, "The Metamorphosis of Tobacco,'* ( 1602 ) and is dedicated to his friend 'Maister Michael Drayton,' whom he asks to take up the lines,

Tobacco like, unto thy brain

And that divinely touched, puff out the smoke again.

Ambitious to excel and full of noble endeavour he exclaims,

Let me the sound of great Tobacco praise

A pitch above those love-sick poets raise.

$\mathrm{He}$ conceives the idea of a parliament of the elements assembled to hear the complaint of Prometheus that his work is imperfect. He calls for help, and the Earth is invoked. But 'Grandame Ops her grieved head did shake.' She declares however that,

A plant shall from my wrinkled forehead spring

Which once enflamed with the stolne heavenly fire

Shall breath into this lifeless corse inspire.

Despite of Fate the elements combine to form the plant. Their work accomplished, it is found that Tellus had tempered too much terrene corruption in its composition. But for this

* On the title-page is a picture of a bi-forked hill with a tall Virginian tobacco plant growing in the cleft. A scroll bears the motto, Digna Parnasso et Apolline. There is an excellent copy of the work in the long-room of the British Museum. 
The man that tasted it should never die But stand in record of eternitie.

Jupiter is enraged at the daring attempt to usurp his divine prerogative and banishes the plant to an unknown region. After long searching the graces discover it in the palace of the great Montezuma. They are royally entertained and wish for no greater happiness than to remain eternally regaling themselves with the vapour of the divine herb. Another flight of fancy reveals the 'sweet and sole delight of mortal men' as a nymph of Virginia receiving the visits of Jupiter clad in the garb of a shepherd. Juno, ever watchful over the movements of her lord, discovers the intrigue, and with threatening gesture storms at the poor thing and transforms her into the Indian weed.

It may be that the divine afflatus which Drayton, speaking of Marlowe, says, 'rightly should possess a poet's brain,' imaging ' those brave translunary things that the first poets had,' had not yet descended upon the young poet of Grace Dieu. But it cannot be denied him that his diction is stately, and that at times he displays flashes of grandeur. Chalmers remarks of him that he brought to his task 'a genius uncommonly fertile and commanding.' All through his brief career he had yearned after a true poet's renown. 'No earthly gift,' he wrote, 'lasts after death but fame.' And he sighed over the thought that all his labour should be left incomplete-'That's my vexation, that's my only grief.' His longing for posthumous fame Drayton tenderly notices in the following lines:

Thy care for that which was not worth thy breath.

Brought on too soon thy much lamented death.

But heaven was kind and would not let thee see

The plagues that must upon this nation be. 
It is hard to say what plagues Drayton refers to, but it does seem unkind of Elizabethan scholars to have so neglected Sir John Beaumont, the purity and simplicity of whose life and elevated tone of work place him in marked contrast to his more versatile and distinguished brother, Francis.

Leaving the domain of the poet let us turn our gaze for a moment towards the heavens. Night's sable mantle shrouds a sleeping world, and all is repose save the spirit of our dreams. Freed from control the ever active one flits at will in the realms of fairy-land, overleaping all difficulties, revelling in phantasms new and wonderful till day dawns, when she returns to her abode in man's heavy brain to lighten the labour of his daily toil, and to store up memories of a world closed to mortal eyes.

A distant murmur as of an approaching storm disturbs the stillness of the night, from gathering clouds serpenttongued lightning flashes across the sky; the furies rage, the curtains of the heavens open and lo! Jupiter appears glowing with unwonted fire. He vors he will suffer no longer the flouting scorn of imperious Juno, and with angerdistended nostrils he sniffs the ethereal air. But what is this that steals over his heated senses? Subduing, soothing, consoling more sweetly than incense from Aphrodite's favoured altars. It ascends in cloudy wavelets from the abodes of mortals. He determines to hold a council of the gods and summons thereto the heroes of Earth famed throughout Elysium for their knowledge of the odic essence whose spirit has entered his own and quelled the rising of a conjugal storm.

Silently there glides into view a ohost of genial witnesses to St Nicotine's balmy influence over the troubled spirits of mortals. Leading the spectral throng are Ben Jonson 
and Drummond, Beaumont and Fletcher, Dekker and Overbury, swathed in clouds of vapour as if comforting themselves with the old delectable pastime. A little to the rear, pale in the majesty of thought, are Shakespeare and Bacon, Spenser and Newton. Leaning to his friend Shakespeare, Bacon whispers, 'No doubt the weed hath power to lighten the body of mortals and enable them to shake off uneasiness. But where is Raleigh? He paid devotion to his divinity most constantly, and ought to be able to speak of what return he got for all his worship.'

'You know, Drummond, as well as I do, that I always did love the weed, in spite of all that King James said against it. Did I not make my prince of swaggerers, Captain Bobadil (who was to me what Falstaff was to Will Shakespeare) descant on the fragrant theme, thus :-

"I have been in the Indies where neither myself nor a dozen gentlemen more of my knowledge have received the taste of any other nutriment in the world for over a space of one-and-twenty weeks, but the juice of this simple only. Therefore it cannot be but 'tis divine-especially your Trinadado; your Nicotian is good also. By Hercules! I do hold it before any prince in Europe to be the most sovereign and precious herb that ever the earth tendered for the use of man." "

'But, O worthy Ben, did not the master over-charge his 'prentice when he allowed the braggart to lay on the tinsel with so heavy a hand?'

Listen to me, my masters, let Ben Jonson read the Untrussing of the Humorous Poet without blenching if he can, for that might advance him in merit; he would acknowledge that Thomas Dekker can kick.'

'Hist! feather-brained gossip; proclaim not so loudly thy kinship with the asinine family.' 
Advancing with measured step the noble Raleigh appears and is greeted with the cry :-

Hail, mighty Raleigh! to whose name we owe

The use and knowledge of this sovereign plant.

To which the illustrious knight made answer, 'Not so, gentle spirits of the past; to me it was not given to be the discoverer, or the first to bring to my countrymen a knowledge of the blessed herb whose sobering and soothing virtues lend man strength to bear with tranquility the injustice of the powerful. The honour you would do unto me belongs of right to others who were before me in the fray of battle and adventure. Humble service have I rendered at her shrine, receiving thereby sweet refreshment unstinted, even when on the threshold of thy domain, $\mathrm{O}$ mighty Jupiter.

'Yet, by your leave, I will relate something of the wonderful tales told of this weed by the adventurers who first brought tidings of it to Europe, and of the New World and its people they had discovered in the far-off western seas.

' The chiefs and headmen of the Indians avow that the herb is a most precious gift of the Great Spirit who created them, and who rules over the affairs of their daily lives. $\mathrm{He}$ it was in ages long past, when all the different tribes were warring one against another, had taught them the peaceinspiring virtues of the plant. He it was who, out of a fragment broken from the red rock, had fashioned for their guidance the first peace-pipe. And it came to pass in this wise: The Master of Life, the Great Spirit that broods over creation, descended to the summit of the mountain; he called his children together, and they obedient to the divine command assembled in infinite numbers to hearken 


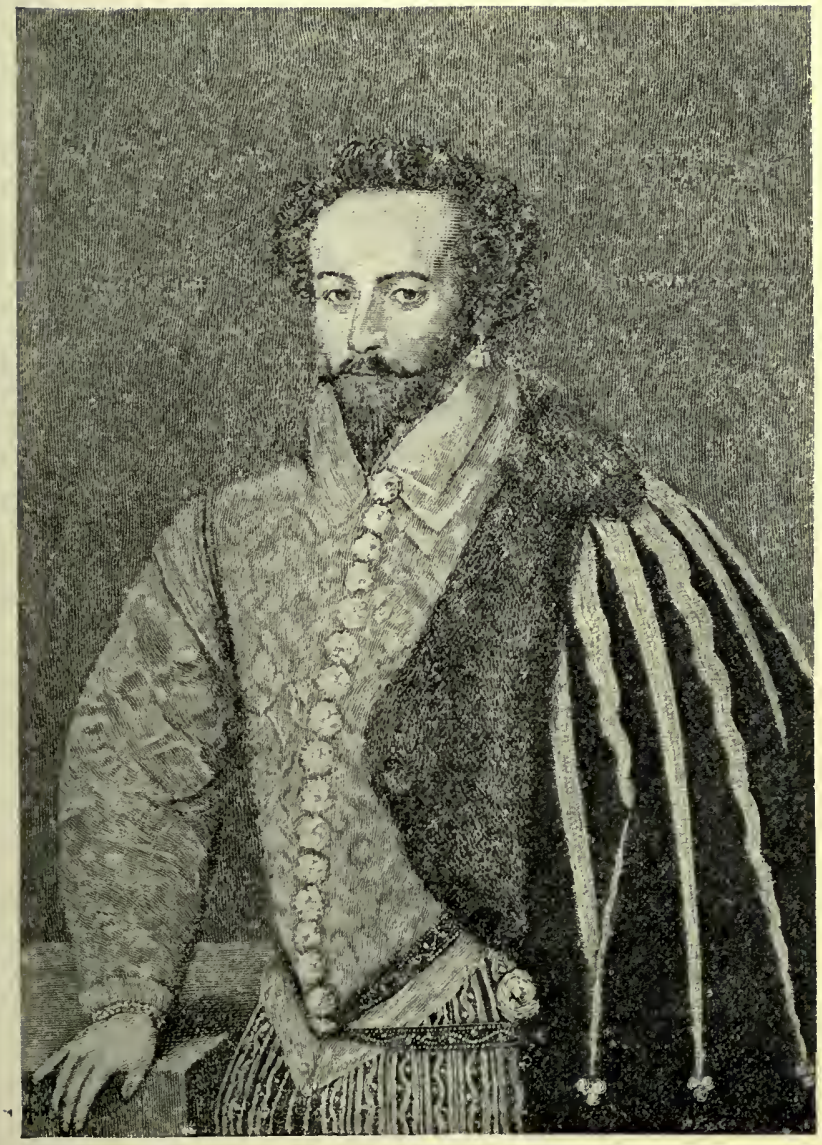

Sik WAltik RaliciH. 

to his will. Then there came forth from the mountain a voice, crying, "Listen, O children of the redskin, to the words of your Great Father. Let your deliberations, domestic as well as public, be conducted under the soothing influence of the herb of life, the divine uppowoc. Let the pipe be to you a symbol of peace between you yourselves and all the tribes of men. In loving brotherhood let it be passed from the lips of those famous in the war of words as in the strife of battle; from those seated on the front bench in the possession of treasure to those of the hungry of the assembled senators who have nought but who fain would have all. Let the smoke-cloud that ascends from the calumet be to you a pledge of peace, of personal amity and good-will. Then shall your compacts one with another be held sacred before me, and the warclub be buried deep in the earth. Henceforward shall friendship and fraternity be yours for evermore-till, alas, they of the pale face have grabbed from you your lands, and the red man hath become a stranger and an outcast in the country of his birth."

"Thus spoke the Master of Life to his children of the redskin. Having fashioned with wondrous curves the emblem of happiness out of stone of the red rock, he filled the bowl with the leaves of the sacred herb, and commanded the lightning to kindle it into flame. High up on the mountain over their heads he smoked the first great symbol of peace among the nations. He told the assembled multitude that the rock, out of which the pipe was made, was formed of the flesh of their grandfathers, long ages ago, when the world was deluged and the people of the earth destroyed. Seeing the gathering of the waters, the children of the forest and of the prairie fled to the high lands, thinking thus to save themselves. The waters 
pursued them; they were overwhelmed in one mighty mass and their bodies were" converted into the red sandstone rock of the mountain, therefore is it good medicine.

'Yet one escaped the flood. A maiden, Kwaptahw, finding herself bereft of kindred, lay disconsolate on the mountain ridge. Then it came to pass that espying her from afar, the great war-eagle came to her side. She clung to the lord of the air, and he carried her to a place of safety high up on an adjacent cliff.

' Then like the murmur of distant waters, the voice of the great spirit gradually melted away.

"-The Master of Life ascending

Through the opening of cloud curtains,

Through the doorways of the heaven,

Vanished from before their faces,

In the smoke that rolled around him

The pukwana of the peace-pipe." '

The shadowy form of great Elizabeth's gallant courtier gives place to the Shepherd of the Muse, who, as he passes, beams upon his friend a countenance of supernal sweetness. Then in a voice of dreamy reverie the genius of the Faervie Queene addresses the Olympian deity after this manner :-

'While musing on the loves and adventures of chivalrous knights and ladies fair, away from the busy haunts of men in the wilds of Kilcolman,

Under the foot of Mole, that mountain hoar,

Keeping my sheep among the cooly shade

Of the green alders, by the Mulla's shore;

There a strange shepherd chanced to find me out ;

Whether allurèd with my pipe's delight

Whose pleasing sound yshrilled far about,

Or thither led by chance, I know not right ; 
Whom, when I askèd from what place he came,

And how he hight, himself he did ycleepe

The shepherd of the ocean by name,

And said he came from main-sea deep.

$\mathrm{He}$, sitting me beside in that same shade,

Provokèd me to play some pleasant fit,

And when he heard the music that I made,

$\mathrm{He}$ found hir:self full greatly pleased at it ;

Yet, æmuling my pipe, he took it in hond

My pipe-before that æmulèd of many-

And played thereon (for well that skill he conned):

Himself as skilful in that art as any.

He piped, I sung; and when he sung, I piped;

By change of turns each making other merry ;

Neither envying other nor envied,

So piped we, until we both were weary.

'Thus, O Jupiter, and you my fellow-denizens of Elysium, would we hold sweet communion of soul. And then it was I learnt of the right noble and valorous knight, the exceeding comfort of the "soverane weed," which the elements in aforetime had formed for the solace of men and gods; for nothing loth am I to say that I drew from the pipe a foretaste of the peaceful joys of the blessed, and therefore did I recognise in the divine herb a gift from heaven, treasured up for mortals in Nature's bounteous store. It seemeth, however, that the immortal powers swayed by imperious Juno had disowned the Virginian nymph and had lost the healing balm she breathes upon the chafed and fretful ; yet, methinks, even Juno might find a piquant pleasure in a few whiffs of the weed.

' But if Raleigh denies himself the renown of being the first to bring the Indian's herb to his native country, he can fairly lay claim to the pleasure of having first planted it in Ireland. When he was Mayor of Youghall, and his abode 
the manor-house, he smoked his first pipe of tobacco in his garden, sheltered by the spreading branches of four yew trees that still may be seen forming a thatch-like covering for a summer-house. And in this Youghall garden he planted Ireland's first instalment of the Indian weed. Ever foremost among the high-souled and adventurous, he neglected not other like humble things that he thought would be of service to his fellow-creatures, for here, too, he planted and cultivated Ireland's greatest blessing, the potato, which fostered by prudence, rapidly gave to that wild and lawless land an abundance of food for the impoverished peasantry. He planted likewise, the affane cherry, and the sweetly perfumed wall-flower, which he had brought from the Azores, and which may still be seen growing on the banks of the Blackwater.

'Much doubting me if aught I have said can profit this goodly company, I will call upon one who has seen the plant in its native soil and can describe its uses among the Indians. For the herb, which is commonly called tobacco, hath many names and divers virtues.' Then rose before the recumbent throng, the historian of England's first colony in the New World, Thomas Harriot, mathematician and astronomer. He began :-

'A brief and true report I will render you of what I learned of the herb, the truth of which can be attested by Ralf Lane, the worthy governor of the new found land of Virginia. It befel me that I went out with a number of my countrymen to that far-off land in the Western Seas the great Columbus had discovered, that I might make record of all that happened concerning us on that perilous venture. It was undertaken by the orders of Sir Walter Raleigh, and was under the command of Sir Richard Grenville. Soon after we had made our peace with the natives, and they 
were of a peaceful race, not caring for bloody strife or for plunder, we found them making a fume of a dried leaf, which they rolled up in a leaf of maize, of the bigness of a man's finger. By rubbing a stone with a stick, in a cunning way they had learned from some divine power, they contrived to kindle fire and putting a light to the leaf they smoked it, as is done by mortals in these days. It was the leaf of an herb which is sowed apart by itself and is called by the inhabitants uppówoc. They use it also in powder. The leaves thereof being dried and crushed small, they take the fumes or smoke thereof by sucking it through pipes made of clay into their stomach and head, from whence it purgeth superfluous humours, and it openeth all the pores and passages of the body, by which means the use thereof preserveth the body in health, and they know not many grievous diseases, wherewithal people in England were oftentimes affected.

'This herb is of so precious estimation amongst them that they think their gods are marvellously delighted therewith. Whereupon they sometimes make hallowed fires and cast some of the powder therein for a sacrifice; being in a storm upon the waters, to pacify their gods they cast some into the air and into the water: so a wear for fish being newly set up they cast some therein and into the air; also after an escape from danger they cast some into the air likewise; but all is done with strange gestures, stamping, sometimes dancing, clapping of hands, holding up hands, and staring up into the heavens, uttering therewithal and chattering strange words and noises.

'We ourselves, during the time we were there, used to smoke it after their manner, as also we did when we returned home and found many rare and wonderful experiments of the virtues thereof, of which the relation would 
require a volume by itself. The use of it by men and women of great calling as else, and many learned physicians bore testimony to its exceeding good qualities as a healer of the sick and a comforter in adversity.'

Then rose England's unexampled smoker, Dr. Parr, renowned throughout Europe for his profound learning, theology and Greek. Smiling benignantly under the voluminous wig which furnished Sydney Smith with a droll figure of speech, he recounts the story of how his smoking had caused royalty to sneeze. This had happened on the occasion of a dinner given in honour of the Duke of Gloucester at Trinity College, Cambridge. Immediately the cloth had been removed the doctor began his usual practice of smoking his pipe. In the warmth of conversation he blew clouds so vigorously that a general rising in revolt took place led by his Royal Highness sneezing and holding his nose.

As to its effect upon the learned doctor, his physician, Dr. John Johnstone, explains that tobacco-smoking acted upon his patient like a charm, allaying his abnormally irritable nervous system. 'It soothed him and assisted his private ruminations; it was his consoler in anxiety, and helpmate in composition. All who knew him had seen the air darkened with the fumes from his pipe when his mind was labouring with thought. Yet he lived the span of years allotted to mortals, falling ripe at the age of seventy eight.' Thereupon a voice was heard protesting against the practice of smoking, in all hours and all occasions, even in the presence of ladies. 'Were you then the divine who refused to dine out or spend an evening with a friend unless privileged to smoke when and where you pleased, even in the drawing-room of ladies, nay, would oftentimes single out the handsomest one to light your pipe?' 
- Truly your apprehension in this is in no wise at fault, nor would I mislead you as to pressing the ladies into the service of my pipe. I recognised that it was nature's behest to woman to impart to duller mortals light and leading, and by watchful eye and ready wit to keep the flame aglow. You did not profit by observation or experience, else you would have learned this lesson.'

'Your pardon, Dr. Parr, but I cannot conceive that you properly maintained the dignity of your calling by such discourtesy to the ladies. Of this am I conceived that had you so behaved in the presence of my wife she would have called you to better manners, unless, indeed, you had been entreated by the ladies to smoke as you did and blow fumes into their faces.'

'Gently, gently, my sapient critic, mistake not the significance of the argument, which is this: Woman by divine command is man's companion and helpmate through their earthly career. Shut her out from all participation in man's social enjoyments, particularly one which like the Indian weed brings to the ruffled mind solace and an abiding peace, and there will spring up in her heart a feeling of resentment, as of a rival, which may find vent in lost tobacco or broken pipes. Therefore is it not well to teach the ladies to take pleasure in your smoking habit rather than leave them to find pleasure in putting your pipe out? And to thee, $O$ troubled one, whose throne is the mighty Olympus, would I say that in St Nicotine's soothing charm dirells an antidote to Juno's censorious tongue, and in her clouds a shield against Aphrodite's gracious influence.'

A smile plays across the countenance of Jupiter, but scorn flashes from Juno's lustrous eyes. And Aphrodite flutters her wings in dissent, for already she feels her sway 
over mortals yielding to the rising power of St Nicotine of the peace-pipe. Casting her longing gaze towards the place of her birth.

To the Cyprian shores the goddess moves

To visit Paphos and her blooming groves,

Where to the Power an hundred altars rise, And fragrant odours scent the balmy skies. 


\section{SYMPOSIUM}

\section{CHAPTER II}

\section{PART II}

A few more whiffs from my cigar

And then in Fancy's airy car

Have with thee to the skies.

How oft the fragrant smoke upcurl'd Hath borne me from this little world And all that in it lies.

Thomas Hood.

Like a sun-gleam seen through a Scotch mist the hoary head and set visage of the veteran thinker, Thomas Carlyle, appears. As a persistent preacher of the gospel of silence he will himself talk and talk on, seemingly oblivious to its application to himself. Turning to his friend, Dr. Calvert, he asks, "Why are we here? Really, I think it shocking that we should run to Rome, to Greece, and leave all at home lying buried in nonentity. Were I supreme chief there should be a resurrection of the old English ages. I will pit Odin against Jupiter, and find sea-kings that will put Jason to shame. Ah, tobacco! It is one of the greatest benefits that ever came to the human race. Nobody ever came near me whose talk was half so good as silence with my pipe. I would fly out of the way of everybody, and would much rather smoke a pipe of 
wholesome tobacco than talk to anybody just now. I saw in the weed the one element in which by European manners men could sit silent together without embarrassment, and no man was bound to speak one word more than he had actually and veritably got to say. Nay, every man was admonished and enjoined by the laws of honour, and even of personal ease, to stop short at that point ; at all events, to hold his peace and take to his pipe the instant he had spoken his meaning-if he chanced to have any. The results of which salutary practice, if introduced into constitutional parliaments, might evidently be incalculable. Take for example, the Tobacco Parliament of Friedrich Wilhelm. It had not the least shadow of a constitutional parliament, nor even a privy council, as we understand it, his ministers being mere clerks to register and execute what he had otherwise resolved upon. But he had his Tabako-Collegium; his Tabagie, or Smoking Congress, and which made so much noise in the world and which in a rough, natural way afforded him the uses of a Parliament on most cheap terms and without the formidable inconveniences attached to that kind of institution. In short, he had a parliament reduced to its simplest expression; instead of parliamentary eloquence he had Dutch clay pipes and tobacco provided in abundance. And this was the essence of what little intellect and insight there was in a parliament; all that can be got out of any parliament. Sedatives gently soothing, gently clarifying tobacco-smoke, with obligation to a minimum of speech, surely give human intellect and insight the best chance they can have.'

It was noticeable that the stern denouncer of talk did not say how he, personally, would have liked a seat in a 'parliament reduced to its simplest expression.' Electrical glances passed from one to another of the immortals, 
which clearly indicated that the inflexible one would have kicked the seat from under him, and, taking his stand on the eternal verities, would have lashed with the scorn of his tongue the drowsy dogs into a full recognition of their own worthlessness; would have compelled them to realise that a deliverer was at hand, and that Carlyle was synonymous with Cromwell.

Yet he would not overlook tobacco's failings. Tobacco he averred had done to the German populations important multifarious functions. 'For truly in politics, morality and all departments of their practical and speculative affairs its influence, good and bad, could be traced; influences generally bad; pacificatory but bad, engaging them in idle cloudy dreams - still worse, promoting composure among the palpably chaotic and discomposed-soothing all things into lazy peace that all things might be left to themselves very much and to the laws of gravity and discomposition, whereby German affairs came to be greatly overgrown with funguses and symptoms of dry and wet rot.' Here Germany's great chancellor broke in with hilarity, and said how he was reminded-

'Hold your tongue, Furst, till I have done.' Relaxing into a more social vein, Carlyle described how he became a smoker from the age of eleven, and how his mother would fill his long clay pipe, light it, take a whiff or two, and then hand it to him. 'And as to snuffing, I will tell you what happened to me when I was a very little boy, perhaps not more than four years old, and before I was admitted to the dignity of trousers. I went to the house of two old ladies who were fond of snuff. Their box to me was something wonderful. Either as a cruel jest, or in utter foolishness, they asked me to take a pinch, I, really, not knowing what snuff was. Urged and instructed by the ladies, I took a 
very big pinch indeed. An explosion, or rather a succession of explosions followed, and I thought my head was blown off. My first experience of snuff was my first tragedy.' Whereupon there fell upon the ear strange sounds as of distant revelry re-echoed through ancient halls untenanted, and Olympus rocked under a burst of Jovian laughter.

Charles Lamb, beaming with smiles, is ready to Lamb-pun (lampoon) anybody or everybody, if he will but wa-wa-wait a bit. And Leigh Hunt, aside to Wordsworth, whispers, 'Lamb will crack a jest in the teeth of a ghost, and then melt into thin air at the awful thought.' While Coleridge, of moody brow, brightens under the genial influence of old comrades, and casting reflective glances around him, lives again in the memory of those delightful evenings spent with them, their pipes aglow, in the old hostel where genial Elia and a host of genius loved to foregather.

Sincere, affectionate, loving Charles Lamb, whose childlike heart, so easily touched with the sufferings of others, was full of chivalrous devotion to the sufferer. He turns to Wordsworth and explains his attitude towards the weed. 'Tobacco was for years my evening comfort and my morning curse. For two years $I$ had it in my head to write a poem on the charmer, but she stood in her own light by giving me headaches that prevented me singing her praises.'

'But, my worthy Lamb, you know that headaches come not so much of smoking as of imbibing too freely of that cheery October you like so well? And what strong coarse stuff you would smoke to be sure! Do you remember that even Dr. Parr was amazed at your prodigious powers, and asked how you had acquired the habit ?'

'Ah, yes, I remember, I told him I had acquired it,' (and here a sparkle of humour plays across his face) 'by toiling after it, as some men toil after virtue.' 
'And when your physician wisely admonished you, and would have stopped further indulgence in the weed, at least for a time, confess, naughty man, what was your reply?'

'May my last breath be drawn through a pipe and exhaled in a pun! And yet I would readily admit that,

For thy sake, tobacco, I

Would do anything but die !'

The eloquent 'Robert Hall, England's greatest pulpit orator, takes up the social theme and recounts his first experience of the pipe. 'My association with the fraternity of smokers happened when I was a young man at Cambridge under the guidance and somewhat severe admonition of the learned Dr. Parr, whose pre-eminence among smokers we all acknowledged. Thus early in life brought under the soothing influence of the weed by so profound a scholar, whose knowledge of Greek was the terror and admiration of young men, and feeling the natural desire of youth to imitate the great, I thought I could not in any better way fit myself for his society than by adopting his habit of smoking, and out of a long clay pipe like his. It was then I developed a taste for tobacco which from that time onward never left me. Being pressed on one occasion to explain why I began the practice, I made answer that I was qualifying myself for the society of a Doctor of Divinity, and that my pipe was the test of my admission. Indeed, I began to experience an ill-at-ease feeling whenever the weed and its instrument were not within my reach. I did not care to argue with those people who thought evil things of smoking. If they did not like it I would merely advise them to keep from it. For myself, I was perfectly contented if they would let me alone, and allow me the mild indulgence during my sojourn among mortals.' 
The shade of Charles Spurgeon, the hero of the Tabernacle, glides into view, holding to his lips a churchwarden of ample proportions, as if inhaling the herb's perfumed breath with serene enjoyment. A veteran devotee at the shrine of St Nicotine he claimed a foremost place among Victorian smokers. Morning, noon and night, in season, and, as many thought, out of season, he might be found ensconced in some quiet nook, or perched on a wall, diligently like a devout Parsee keeping the sacred fire aglow, and drawing inspiration from the spiral wreaths as they ascended heavenwards. It was to his nostrils as frankincense, leading his thoughts to cerulean quarries in the sky where gems of sparkling wit (or broad humour) were to be gathered for the delectation of multitudes hungering for even his smallest joke, or it might be, an oracular utterance on the 'Scarlet Lady.' The Tabernacle towered high in the land in those days, and the churchwarden put forth a lengthening stem. And yet there were limits, outside which even the High Priest of the Tabernacle could not be permitted to roam, or to smoke the idolatrous Indian weed unchallenged. Here he relates how a worthy dame of his fold brought him to book on the subject-his everlasting breathing of 'bacco-and demanded of him whether the practice was orthodox: could he put his finger on any part of the Bible and say, here is my authority? Whereupon the pastor meekly answered, 'no, madam. But we do read in the Bible of the people passing through the valley of Baca.' 'The valley of Baca! yes, here it is!' From the clouds leisurely blown around her a new light dawned on her troubled conscience; the gage of battle was withdrawn, and she believed with the implicit faith of a convert in her prophet, priest and king. Others might stray from the beaten track to gain a greener mouthful, 'but for myself,' 
she exclaimed, 'henceforward I shall rejoice in the path that leads to the Tabernacle through the valley of Baca!'

'I love thee!' exclaimed Captain Marryat, in the impassioned strain of a Troubadour for the lady of his heart, 'I love thee! whether thou appearest in the form of a cigar, or diest away in sweet perfumes enshrined in a meerschaum bowl. I love thee with more than a woman's love; thou art a companion to me in solitude; I can talk and reason with thee, avoiding loud, obstreperous argument. Thou art a friend to me when in trouble, for thou advisest in silence, and consolest with thy calm influence over the perturbed spirit. I know not how thy power has been bestowed upon thee; yet, if to harmonize the feelings, to allow the thoughts to spring without control, rising, like the white vapour from the cottage hearth on a morning that is sunny and serene ; if to impart that sober sadness over the spirit which inclines us to forgive our enemies; that calm philosophy which reconciles us to the ingratitude and knavery of the world; that heavenly contemplation whispering to us, as we look around, that all is good-if these be merits, they are thine, most potent weed.'

'A truce to superfine sentiment. Tobacco is all very well as a check to over-vehemence in men, just as a snafflebit is to a rampant horse; applied to the wrong person, it will turn a sluggard into a seventh sleeper. But it has a higher significance, such as you in your speculative dreaming may never have thought of. Herr Carlyle, the friend of the Fatherland, has told you his story of the use and abuse of tobacco in Germany, now I will tell you mine, just as the incident occurred in the old Bund of the times that are past.

' I went to see Rechberg, who was at work and smoking 
at the same time. He begged me to excuse him for a moment. I waited a little while. By-and-by I got rather tired of waiting, and, as he dic not offer me a cigar, I took one out of my case and asked him for a light, which he gave me with a somewhat astonished expression of countenance. But that is not all. At the meetings of the Military Committee, when Rochow represented Prussia at the Federal Diet, Austria was the only member who smoked. Rochow, who was a desperate smoker, would have dearly liked to smoke too, but did not venture to do so. When I came in I also felt that I wanted to smoke, and, as I did not see in the least why I should not, I asked the Presiding Power for a light, which appeared to be regarded both by it and the other powers with equal wonder and displeasure. Obviously it was an event for them all. Upon that occasion, therefore, only Austria and Prussia smoked. But the other gentlemen considered it such a momentous matter that they reported upon it home to their respective governments. The affair demanded the gravest consideration, and fully six months elapsed during which only the two great powers smoked. Then Schrenkh, the Bavarian Envoy, began to vindicate the dignity of his position by smoking. Nostitz, the Saxon, yearned to do so too, but he had not as yet received permission from his minister; but as, at the next meeting, he saw that Bothmer, the Hanoverian, lit a cigar, he (who had strong Austrian proclivities, and some of his sons in the Austrian army) came to an understanding with the Rechberg, for he also drew a weed from its leathern scabbard, and blew a cloud. The only ones now remaining were the Würtemberger and the Darmstädter, neither of them smokers. But the honour and importance of their respective States imperatively exacted that they should smoke; and so, at the very 


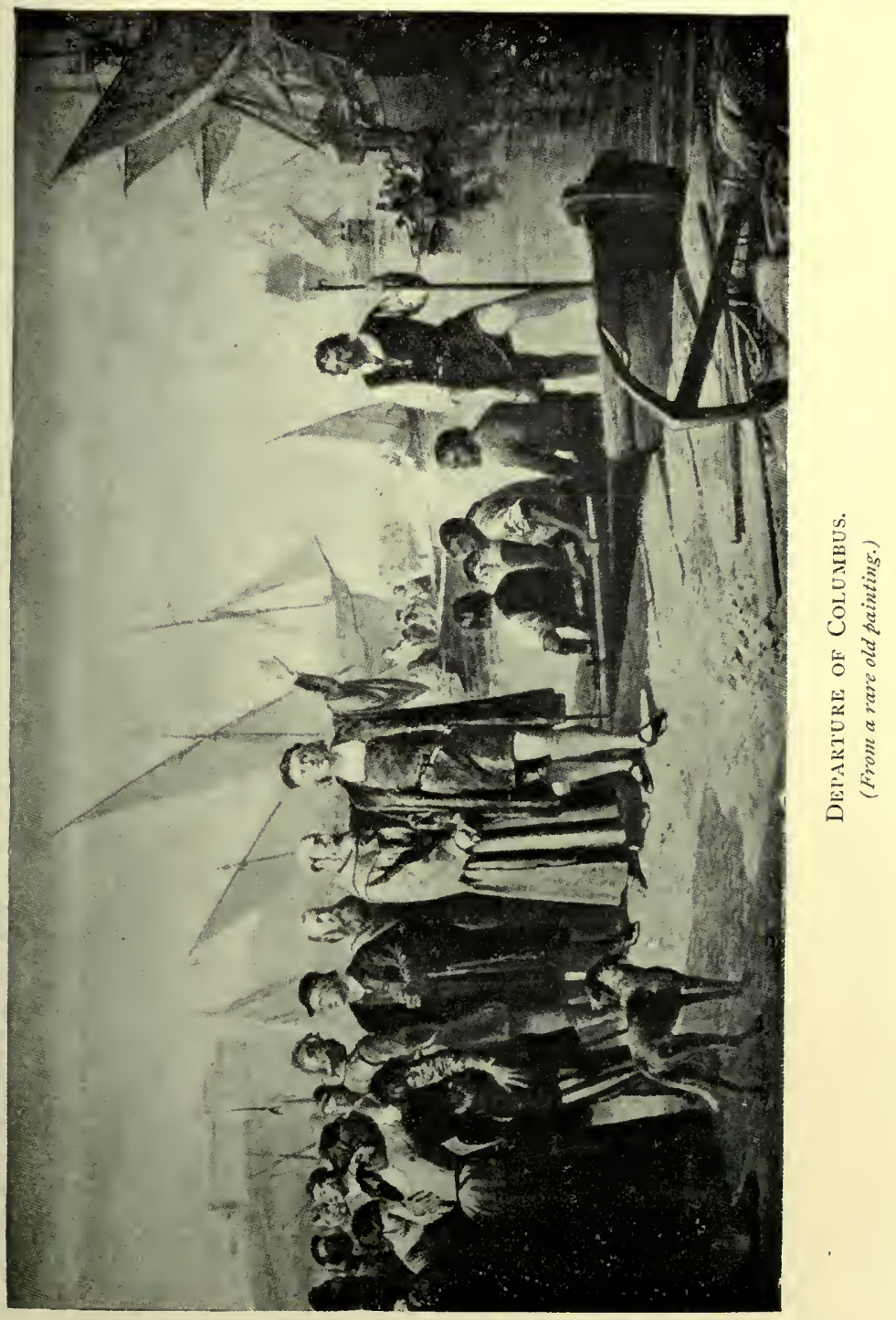



next meeting, the Wurtemberger brought out a cigar. I can see it now-a long, thin, light-yellow thing! and smoked at least half of it, as a burnt offering for his fatherland!

The important part tobacco has played in state affairs would be amazing were it not so laughable; the weed seems to break down barriers with a puff, and to clear the way to mutual understandings where jealousy and infra dig. blocked up the path. It once reached my ears that England's Minister for Foreign Affairs, Lord Clarendon, made his office reek like a cabman's shelter with the fumes of the strongest tobacco. He would never listen to a word against his favourite indulgence without rising in assumed wrath in its defence, and would stoutly maintain that tobacco possessed a potent spell over men's minds, disposing them towards the good side in all the important affairs of life. And Lord Canning, too, could seldom be seen without a cigar in his mouth.

'But as to smoking in colleges and among youths generally, I am firmly convinced that the practice is bad in every way. No youth under the age of sixteen should be permitted to take tobacco in any form, under pain of physical chastisement or public prosecution.'

Prince Bismarck having thus delivered himself, the honour of France demanded that the Grand Nation should not remain silent in the halls of the immortals. An animated chatter among the spectral throng ensues, and mutterings which mark dissension are audible above the general hum.

' Indulgence in tobacco and alcohol are leading directly to the total annihilation of conscience .... the moral sense is blunted, and degeneracy is spreading throughout Christendom. Count Tolstoy is perfectly certain of it, 
according to communications which have reached me through a medium of highly purified spiritual affinities.'

'After dinner nothing ever was so good as a pipe, taken with a glass or two of brandy-not that I cared for alcohol, O dear no! but this I do say, that the more I smoked the better I worked.'

'The depopulation of France is directly involved in the use of the pernicious plant called tobacco, as was proved by my experiments on cocks and rabbits (Dr. Depierris). The manufacture and sale of tobacco are, very properly, entirely in the hands of the government ; it can, therefore, regulate the output, increase or diminish the quantity, or cut off the supply altogether, if either one or the other course be deemed advisable in the public interest. My argument was, in the first place, based upon experiments on animal organisms conducted under my own eyes, and in the second place, on reports furnished by Prefects of Departments. Those reports demonstrated the alarming fact that in ten departments where each inhabitant smoked on an average 1490 grammes of tobacco in the year, the families having seven children and upwards were in the proportion of sixty-eight in every 100,000 of the population; while in ten other departments where the average consumption of tobacco was only $45 \mathrm{I}$ grammes per head, the proportion of families of seven children for every 100,000 inhabitants rose to eighty-one; the still-born children numbered only 156, against 1124 in the former case. Hence the significant inference that the use of tobacco led directly to degeneracy of the human race.'

'But tobacco may be used in moderation without injury, if men would but keep away from the little glasses of brandy, absinthe, and other similar liqueurs.'

'Tobacco produces sluggishness and loss of will power.' 
'On dit, et c'est passé en proverbe; Le tabac c'est l'ami de l'homme, il le console de la femme.'

'Fumer, c'est obtenir une trêve à la tristesse, aux préoccupations irritantes, aux petites misères de la vie, aux chagrins domestiques, aux tracasseries d'un ménage mal assorti; c'est aussi, en matiere de travaux intellectuels et artistiques, se procurer, au moyen d'une surexcitation légere, un développement, une clairvoyance d'idées qui souvent vous fuient, c'est un refuge contre ce qui blesse ou choque, contre le mécontentement de soi-meme ou d'autres; c'est dans les professions manuelles, une diminution des sensations de fatigue, d'ennui, de découragement; c'est aussi, une annihilation du mal qui cause une atmosphere froide, humide, malsaine, c'est enfin une jouissance émanant d'une trible congestion au cerveau, un étourdissement passager, une sorte d'ivresse légere qui caresse les idées et les empeche de vagabonder.'

'En résumé, après tout ce qui s'est dit et écrit pour ou contre le tabac, l'usage de cette plante est aujourd'hui général; il constitue de nos jours une branche très importante de culture, d'industrie et de commerce, et une source de revenus considérable pour les Etats.'

The voice of Fairholt, of rare tobacco fame, claims attention. 'Let us get out of the region of captious criticism and come to the solid ground of fact. For is it not surpassing strange that man still exists on earth if there be death in the pipe? Is his life shorter, his morals worse, his intellect weaker, than in the days of, say, Henry VIII. before tobacco was known in Europe? For three hundred years the poisonous drug, if such it be, circulated in the veins of Europeans, and where is the degeneracy? They are at this day, the most active, energetic and intellectual beings that have ever peopled the planet. The learned 
doctor's awful array of afflictions attested by experiments on small forms of animal life have no terrors for them; experiment and demonstrate as he may, experience is a better teacher. Is there any reason why men should apply to themselves the results of operations made upon creatures that perish of old age while human beings are still in their infancy?'

'No, surely not,' responds Inglis of Indian frontier fame. 'Often did I regale my weary body and brain with a pipe after a hard day's sport with rifle and hound on the track of the beasts of the jungle, or after a fierce bout with the courageous wild boar, whose splendid fighting qualities are little known out of India. It happens occasionally that the huntsman finds himself far out on a desolate track when

The night-cloud has lowered And the sentinel star sets her watch in the sky.

At such times he turns with joy to his ready comforter, the peace-pipe. Breathing in the fragrant breath his thoughts are set free to wander at will; old places are revisited, and lost memories revived, always tinged with pleasing thoughts of the things most cherished and the faces most loved. At peace with himself and the world, he gazes into the starlit heavens and exclaims, "Hail! thou invigorator of the weary, consoler of the sorrowful, uncomplaining, faithful friend." "

'I too, would add my experience of the weed's healthful influence on weary humanity battling with plague and pestilence in tropical lands.' Here Sir Samuel Baker relates how African savages had taught him the virtues of the plant.

' On that continent of dreadful night, yet so fascinating 
to the European explorer, where death in one form or another confronts the traveller at every step, it fell to my lot to be detained at the native village of Obbo during the rainy season, in the midst of an indescribable steam of poisonous vapours arising from a rank luxuriance of vegetation to be seen in no other part of the world. Fever and dysentery were carrying off the natives in large numbers. My wife and myself were both down with fever, when the old chief persuaded me to smoke tobacco, which in the countries bordering on the Nile is cultivated and manufactured in large quantities. I had never smoked in my life, but I then commenced with Obbo tobacco and pipes, and lived to bless the day I was wise enough to make the experiment.

'During our pleasant sojourn in the valley of Albara it was my misfortune not to be a smoker. In the cool of the evening we used to sit by the bamboo table outside the door of our house and drink our coffee amidst the beautiful scenery of a tropical sunset, with deep shadows falling into the valley. But a pipe, the long chibouk of the Turk, would have made our home a paradise. On our return to Gondokora I found that the plague had visited the town during our absence, and that the vessel we were to go in to Khartoum was plague-stricken, many of the crew having died of disease. I was so thoroughly convinced of the purifying properties of tobacco that upon the circumstance coming to my knowledge I at once ordered several pounds of tobacco to be burnt on board, chiefly in the cabin, and with the satisfactory result that we all escaped the plague.'

William Makepeace Thackeray grows pugnacious in defence of his favourite indulgence, and asks, "What is this smoking, that it should be considered a crime! I believe in my heart that women are jealous of it, as of a rival. 
The fact is that the cigar is a rival to the ladies and their conqueror too. Do they suppose they will conquer? Let them look over the wide world and see for themselves that their adversary has overcome it. Germany has been puffing for over three-score years and more, France smokes to a man. Do they think they can keep the enemy out of England? Pshaw! Look at Nicotiana's progress. Ask the club-houses. I, for my part, think it not at all unlikely that a bishop may be seen now and then lolling out of the Athenæum with a cheroot in his mouth, or at any rate, a pipe stuck in his shovel hat.'

Bulwer Lytton waxes warm over the inestimable blessings of the pipe. He declares that it is a great comforter, and a pleasant soother! 'Blue devils fly before its honest breath! It ripens the brain, it opens the heart; and the man who smokes thinks like a sage, and acts like a Samaritan. He who doth not smoke hath either known no great grief, or refuseth himself the softest consolation, next to that which comes from heaven. What, softer than woman? Yes, for the woman teases as well as consoles. Woman makes half the sorrows which she boasts the privilege to soothe. Woman consoles us it is true, while we are young and handsome, when we are old and ugly, woman snubs and scolds us. On the whole, then, woman in this scale and the weed in that; Jupiter, hang out thy balance and weigh them both; and if thou give preference to woman, all I can say is, the next time Juno ruffles thee-O Jupiter! try the weed.' 
THE HOME OF THE INDIAN WEED

The white man landed-need the rest be told?

The new world stretch'd its dusk hand to the old.

Each was to each a marvel, and the tie

Of wonder warmed to better sympathy.

THE ISLAND.

LOOKING back towards the source whence the old world derived the Indian weed and the habit of smoking it, the career of Columbus presents itself crowded with marvellous exploits and instances of indomitable courage that have left their imprint on men's minds for all succeeding generations. Though an old and oft-repeated story it has an abiding interest for adventurous explorers whose highest glory is to link themselves with the free and fearless Vikings. His imagination aglow with the wondrous story Marco Polo had told of his voyages in the far east, and possibly under the prompting of Toscanelli whose map was his guide, Columbus conceived the bold idea of reaching India by sailing west. Difficulties inevitable to so daring a project were met and overcome with the patience born of genius. At last he gained the ear of Queen Isabel, and to her he poured out his heart's grief, and made her acquainted with the dream of his life. Pointing to his chart he pictured a new world teeming with 
every precious thing of earth, where wealth, and power, and majesty, were to be won by courage and enterprise; and all should be hers were he but equipped with royal authority and means of transport. The sincere, impassioned eloquence with which he pleaded the reasonableness of his cause and its triumphant success enlisted the sympathy of the noble-hearted Queen. She entered with spirit into the grand scheme that was to bring renown and riches to her impoverished country. 'I will assume the undertaking for my own kingdom of Castile,' she exclaimed, 'I will pawn my jewels if the money you raise is not sufficient.'

On Friday, August 3, 1492, Columbus set sail from the bar of Saltos, near the little maritime town of Palos (Andalusia), as admiral of the three small ships his indomitable energy had brought together. His own vessel, the Santa Maria, had been built expressly for the voyage, and was manned by a crew of fifty ruthless, unskilful adventurers. The two others were caravels named the Pinta and the Nina; they were owned by the Pinzon family, and were commanded, respectively, by Martin Alonzo and his brother Vicente Yañez. In all one hundred and twenty men embarked under the inspiriting influence of Columbus on their perilous adventure into unknown seas. Three months have well-nigh passed and yet no sign is visible of the promised land. After enduring hardships the severest, worn out by storm and tempest in regions leading they knew not whither, their murmurs deepen into open mutiny; the crew gathers round the great captain with threats to throw him overboard unless he will turn the rudder and sail home. The vision of Columbus rises before us : tall, fair, blue-eyed, beaming with the confidence of a life's devotion to a great purpose, he confronts his 
boisterous crew, and, with chart in hand, once more subdues them with an enthusiasm fired by profound conviction. On the morning of October I2, a sailor, Rodirego de Triano on board the Nina scanning the horizon, calls to his mates to look out for land, pointing to a dark mass looming in the distance. Then there breaks forth from the mast-head the wild cry, Tierra! Tierra! and the helmsmen steer their course into the calm waters of San Salvador.

Here among the fair Bahamas where on Nassau's most conspicuous site is reared a statue to Columbus, let us linger a moment while the great navigator and his adventurers prepare for landing in order to take possession of the new territory in the names of their Majesties, Ferdinand and Isabel. Richly attired in scarlet and plumes, and accompanied by the two Pinzons, with a chosen escort bearing the standard of Spain, they enter their boats and are rowed to the shore. With tears of joy Columbus kneels and kisses the ground, while thanking Heaven for the great mercy vouchsafed to him and his companions. Very soon they become aware that the island is populated; they see natives running hither and thither, peering from among the trees that stretch down to the shore, and making gestures to one another in evident amazement. By-and-by they approach nearer and nearer to the white men; now they throw themselves on the ground in attitudes of wonder and supplication. Columbus is struck with their child-like simplicity; he reassures them, offering to each some trifling articlebeads, buttons, etc.-which they take with eager delight. Their curiosity leads them to touch the hands and faces of the white men, whose garments are a great surprise. From a creek hard by canoes shoot out into the open, 
but the moment the occupants see the towering vessels of the Spaniards with their flapping sails, amazement strikes them dumb and motionless. Columbus directs his men to capture them, but the spell broken, they struggle desperately and plunge into the water. Two, however, are secured and brought on board, where they are treated with the utmost kindness by Columbus, for he wishes to learn from them something of their language, their country, and its products, particularly about gold and where it is to be obtained.

The gladsome sight that everywhere met their eyes must have been very refreshing to the weary mariners. As far as the eye could reach there was a luxuriant vegetation, and a forest of trees bearing an amplitude of rich and varied fruit stretching down to the shore temptingly overhanging its sides, as if inviting the strangers to feast and enjoy the good things of this Elysium. Perennial springtime seemed to reign over the happy island, whose inhabitants knew no want nor suffering. Its waters were liquid sapphire and malachite, looking through which could be seen graceful branching corals; sky-blue fishes playing hide-and-seek with golden ones among a delicate network of purple and yellow; there, too, were miniature willows of lilac, and many another rare thing in the mermaids' pleasure gardens. Here and there the coast was strewn with shells of exquisite beauty-trumpets for Tritons; the king conch, out of whose pink lining lissome fingers create lovely cameos; tiny rice shells, pink ones like ladies' finger-nails, and cowries, and many another rare shell that, in the days of England's shell mania, would have realised a handsome fortune for the happy possessor.

Sailing amidst these scenes of wondrous beauty they, 
sixteen days later, October $\mathbf{2} 8$, sighted the island of Cuba, to which Columbus gave the name of Juana, in honour of Prince Juan. In his selected letters, translated by R.H. Major, F.S.A., Columbus says : 'I followed the coast westward, and found it so large that I thought it must be the mainland, the province of Cathay, China.' Continuing his narrative he says, 'And as I found neither towns nor villages on the coast, but only a few hamlets with the natives of which I could not hold conversation because they immediately fled, I kept on the same route, thinking I could not fail to light upon some large cities and towns. . . . Returning to the harbour I had remarked, I sent two men ashore to ascertain whether there was any king or large cities in that part.'

Cruising in this region of enchantment, Cuba had fallen upon his enraptured gaze like a vision of Eden. Soft and gentle breezes, an azure sunlight sky, a rich luxuriant landscape, the carolling of birds, exercised a powerful influence over his imagination. He exclaims: 'It is the most beautiful island the eyes ever beheld. I am told that the trees never lose their foliage, and I can well understand it, for I observed they were all as green and luxuriant as in Spain in the month of May. Some were in blossom and others bearing fruit, others otherwise, according to their nature. The nightingale was singing as well as other birds of a thousand different kinds, and that in November, the month in which I myself was roaming amongst them.'

After an absence of three days, the two men whom Columbus had sent to explore returned. They had found no king nor large city, but had come upon many small hamlets with numberless inhabitants; yet nothing could be seen that in any way corresponded to their ideas of settled government. On their way back they for the first time 
witnessed the use of a herb which, says Washington Irving, 'the ingenious caprice of man has since converted into an universal luxury in defiance of the opposition of the senses.' Among other tales, strange and wonderful, the two men told how they had come upon naked Indians with lighted firebrands in their mouths, from which they drew in the fumes, expelling them-again through their nostrils! They were simple, inoffensive people, and well disposed towards the white men, whom they allowed to examine their fire-brands. They had found them to be composed of the dried leaves of a herb rolled up tightly in a leaf of maize. Lighting one end of the roll, they put the other end between their teeth, and inhaled the fragrant vapour with an air of placid enjoyment which seems to have produced in the Spaniards a craving for the weed that to this day has never left them.

Here was a race of beings living in happy ignorance of the strifes and ambitions, the anxieties and vexations of civilised man, reclining in every posture of ease while breathing the fragrant odours of their treasured weed: civilised man, indeed, gazed with amazement and longing. Sweeter far than incense from Arabi was this new delight to the Spaniards, it became a necessity; it was their morning comforter that fortified them for the combat of the day, and their evening solace. Thus it happened that the new world gave to the old its first lesson in the art of regaling tired nature with her own anodyne. Navarrete says: 'The habit has since become universal, and hence the origin of the so much prized and so far celebrated havanas.'

With the experiences of a new world just dawning upon them, the explorers were prepared at every step to encounter prodigies of a startling character. So far, however, they had seen nothing to cause them apprehension; nothing had yet fallen in their way more interesting than these primitive 
people clad merely in nature's copper-coloured cuticle, and adorned with ornaments of pure gold and rare and curious shells intermingled with their braided locks. And yet still more strange, these very simple-minded children of nature looked up to the white men as visitors from the spirit-land of their dreams, and with awe and wonder made offerings to them of whatever things they esteemed most precious. The ships in the offing with flapping wings had come from the blue beyond their ken, and the white men were denizens of the skies. This curious idea-so soon to be dispelled by the rapacity and cruelty of the Spaniards-which the natives had conceived of the strangers is alluded to by many early writers who afterwards visited the new world. Sir Francis Drake, in The World Encompassed (1572-73), speaking of the North American Indians, says: 'They brought to the ship a little basket made of rushes and filled with a herb which they called tabah. . . . They came now a second time bringing with them as before had been done, feathers and bags of tabah for presents, or rather, indeed, for sacrifice, upon this persuasion that we were gods.'

The chief object Columbus had in view, that indeed which had secured him the powerful influence of the Church, was not merely the discovery of the marvellous country of the East Indies, mentioned by Marco Polo, but the conversion to Christianity of the Grand Khan who ruled over the land. To this end, and to obtain for him friendly treatment, he bore for the Khan a royal letter of introduction signed by their Christian majesties of Spain.

Meanwhile, Columbus had been busily occupied in collecting the spoils of his easily acquired possessions in the West India Islands, in readiness to return home and render an account to his magnanimous friend and protectress, Queen Isabel, of the perils of his voyage and the ultimate 
realisation of his dreams. His own vessel, the Santa Maria, having run aground had to be abandoned, but the Nina was soon made ready for him, and without undue delay the little craft weighed anchor on January 16,1493 . On his arrival in Spain the Court was at Barcelona, and thither Columbus journeyed, attended by his train, bearing the trophies of his adventure. He was received by the king and queen with every mark of royal favour. Seated in their presence, he displayed to their eager gaze the specimens he had brought for their acceptance of various products of the new found land: virgin gold, cotton, mysterious plants (assuredly the tobacco plant would be here), birds of rare plumage, and animals of unknown species. But rising in importance above all these things were nine native Indians for conversion and baptism to attest to the reality of his triumph. Though the Grand Khan had not been seen, yet in presence of these Indians even the learned Bishop of Talavera could no longer look askance at the great navigator as a vain dreamer not altogether free from suspicion of magic. In grateful remembrance of Her Majesty's bounty and enthusiastic protection, Columbus presented to her the casket which had contained the jewels she so generously gave up for his use, now filled with pure gold, as an earnest of what was in store for Spain in their Majesties' new dominions. The casket is preserved to this day in the sacristy of the cathedral at Grenada.

Columbus was of too active a disposition to indulge his well-earned repose; the old craving for adventure and exploration left him no peace. Under royal command a fleet worthy of his grand scheme of conquest and colonisation was prepared for him, consisting of three large galleons and fourteen caravels, carrying $1,500 \mathrm{men}$, and all things necessary for the establishment of a new colony. He was 
invested with supreme authority as admiral, viceroy, and captain-general of all islands and continents in the Western Ocean. Second in authority was Gonzalo Fernandez de Oviedo, who accompained the expedition bearing the royal commission of inspector-general of the West India Islands. By the end of September 1493 the fleet was speeding its way towards the Far West, and with favouring gales was wafted straight amongst the Windward Islands. Had some good genius guided their course across the deep in order to disclose to them the beauties of the new world, no fairer island could have been found than the one which, on that bright morning in January 1494 lay before the adventurers as the great master mariner steered his vessel into the safe harbour of Hayti-land of mountains. The climate was perfect; a perpetual summer was tempered by cool mountain breezes and periodical showers, which swept in from the Atlantic. By the banks of this beautiful harbour, on the north shore, Columbus planted the first Spanish settlement, and in grateful tribute to the Queen he named it Isabella. The country, which in all probability he believed to be the continent he was in search of, he named San Domingo, a name which soon disappears from the records, substituted by that of Hispaniola. From this island came to Europe the first written allusion to the use of tobacco by the natives. It is from Fra Ramono Pane, a Franciscan, whom Columbus had left at Hayti. In a letter to his friend Peter Martyr, Queen Isabel's secretary, he tells him of a curious practice said to be common among the natives of rubbing the dried leaves of a herb into a powder, and then with a hollow forked tube, two prongs of which they put up their nostrils while holding the lower one in the powder, 'they drew the powder into their noses, which purges them very much of humours. . . The 
cane or tube is about half a cubit long.' This description would seem to indicate snuffing rather than smoking. It seems clear that we have here come upon the origin of the practice of titillating the olfactories which towards the close of the sixteenth century, hæd become, says Molière, "la passion des honnetes gens.' Catherine de Medici became one of the earliest devotees to the new indulgence; fashion led the poudre à la Reine through the courts of Europe, where elegant dilettanti vied with each other in the display of jewelled snuff boxes filled with odeur de Rome, or other right puissant sternutatories, not always of a harmless kind. Prelates and abbés were enamoured of the delightfullyscented refresher, and in Spain they did not scruple to place their brilliant boxes on the altar for their use, in spite of Pontifical ordinances and anathemas from Urban VIII. and Innocent XII. Physicians, carried away with the belief that a grand sternutatory had been discovered, proclaimed its advent to a grateful people, and prescribed its use liberally; for, said they, 'it must needs do good where the brain is replete with many humours, for senselessness or benumming of the brains, and for a hicket that proceedeth of repletion.' Yet there were divisions in the ranks of medical men; there were different sides of the question, different interests or tastes to be considered. Had not the Duc d'Harcourt suffered martyrdom in the new cause in order to please Louis le Grand? The Court physician, Monsieur Fagon, devoted his brilliant talents to a public denunciation of the new vice which, springing from heathen soil, was fast spreading over Christendom! Unhappily for the success his eloquence merited, in the warmth of his oratory he so far forgot himself as to dip his fingers into his waistcoat pocket and take copious pinches of tabac in poudve in order to refresh his fickle brain. 
The early writers on the smoking habit were perplexed about the origin of the name given to the weed. Many favoured the opinion that the plant and its use had first come under the observation of Europeans in the island of Tobago. This notion is shewn to be incorrect in a work bearing the rather long and ambitious title of Tobago: a Geographical Description, Natural and Civil History, together with a full Representation of the Produce and other Advantages arising from the Fertility, excellent Havbours, and Happy Situation of that Famous Island. The author says, 'I do not recollect any author who has given a clear account of this name; and as many have expressed a doubt whether the island was so called from the herb, or the herb from the island, I hope the curious and inquisitive reader will be well pleased to see that matter set in its true light; for the fact is that neither the island received its name from the herb, nor the herb from the island. The appellation is, indeed, Indian, and yet was bestowed by the Spaniards. The thing happened thus : the Caribbees were extremely fond of tobacco, which in their language they called kohiha, and fancied when they were drunk with the fumes of it the dreams they had were in some sort inspired. Now their method of taking it was this : they first made a fire of wood, and when it was burnt out they scattered upon the living embers the leaves of the plant, and received the smoke of it by the help of an instrument that was hollow, made exactly in the shape of the letter $\mathrm{Y}$, putting the larger tube into the smoke, and thrusting the shorter tubes up their nostrils. This instrument they called tabago, and when the Admiral Christopher Columbus passed to the southward of this island he judged the form of it to resemble that instrument, and thence it received its name.' 
Among the continental tribes, however, smoking instruments were found which, in variety of form, originality of design, and skilful execution, equal the best productions of Europe; indeed, they have to the present day served as models for the rest of the world. Those who, inspired by Cooper born-ideals of the noble savage in his native wilds, long for a sight of real Indian life, unspoiled by contact with civilised man, will now look in vain across the American continent. The Indian, to his sorrow, soon learnt the vices of the white man who, by craft and arms, ousted him from his heritage. Occasionally, however, far up the Mississippi valley, or on the confines of the Canadian forests, the desire may, to some extent, be appeased. The observer may with admiration note the fine physique, the strongly marked physiognomy, the untrammelled freedom of these primitive lords of the land. Old chiefs may be seen gravely smoking by their wigwams, while reclining against the trunk of a fallen tree and discussing among themselves the prospects of war or peace, or perhaps congratulating themselves on the accession to their numbers of some neighbouring tribe. A little way off young warriors are furbishing up arms for the chase, or war as may be. Others are elaborately ornamenting with carving and paint their curious tobacco pipes, some of wood with long stems adorned with feathers, some cut out from the treasured red pipe-stone brought from the mountain quarry. Economy of the precious weed is not overlooked, and the inner bark of the red willow is peeled into fine shavings and when dried over a low fire is mixed with the tobacco leaves. Their tobacco pouches well filled they may start on the chase or the war path, assured that they are well provided with refreshment for many days.

Europe, however, is indebted to Oviedo for the most intelligent account of the tobacco plant, and the method 
commonly adopted by the Caribs of preparing and using it. During his tenure of office in the West Indies he collected an immense amount of information relating to the inhabitants, their country and its products, the results of which he published in 1526, under the title of Historia natural $y$ general de las Indias. In the Seville edition of 1535 is an engraving of the smoking instrument used by the Caribs. It is of the form already described. Oviedo says of it that 'it is about a span long; when used the forked ends are inserted in the nostrils, the other end being applied to the burning leaves of the herb. In this manner they inhale the smoke until they become stupefied. And when forked canes cannot be procured, they make use of a straight reed or hollow cane, and this implement is called tabaco by the Indians.' Oviedo speaks disparagingly of the smoking habit, and classes it amongst their evil customs as a thing very pernicious, and done in order to produce insensibility. Remarking on the prevalence of the habit, he says that the consumption of tobacco by the various tribes of the Indians is of universal and immemorial usage, in many cases bound up with the most significant and solemn tribal ceremonies. No matters of importance to the tribe or the family can be conducted, no compact can be held binding, that has not been ratified by the passage of the great pipe, be it the pipe of peace or the pipe of war-the calumet or the tomahawkfrom the lips of one chief to those of the others of the conference. The pipe, then, is their great seal, the solemn pledge of friendship, good faith, and such qualities as the chivalry of the forest suggests to the untutored mind. Although Oviedo regards unfavourably the practice of smoking, he evidently prized the plant, as we read that on his return home he cultivated it in his private gardens. This is but one step removed from its enjoyment in the pipe, and who 
can say that in his retirement he did not take that step? Las Casas speaks so slightingly of his work as to say that it contains almost as many lies as pages. Las Casas, the renowned friend and protector of the poor oppressed Indians, could certainly speak with confidence on matters relating to the West India Islands. He had gone to the colony in the train of Nicolas de Ovando in 1502, and settled in Cuba as parish priest and vicar-apostolic of the islands. Possibly his intimate knowledge of the cruelties practised by his countrymen on the unoffending natives and their insatiable greed of gold, had turned him against all highly-placed officials in the colonies. He agrees with Oviedo, however, in dislike of tobacco-smoking. He says : 'I cannot see what benefit can be derived from it. . . . However extensive it may be in other countries (and common no doubt it is there) the habit has become so general in this [Spain] that, to the discredit of parents, it is even followed by children. . . The eternal cigar is seen in the mouths of old and young, even in that of the ragged urchin.'

The third voyage of Columbus to the Far West, resulting in the discovery of the South American continent, brought the Spaniards into contact with new races well advanced in the arts of civilisation as compared with the condition of the inhabitants of the islands, and opened the way for intercourse and the development of mutual interests of no common order. What use they made of this brilliant opening, leading to the conquest of Mexico and Peru, is told in the fascinating pages of Prescott. Well might the eyes of the Spaniards be dazzled by the splendours they beheld in the palace of the great Montezume, where, on the occasion of their reception by the Emperor, cigars were handed to the guests inserted in tubes of richly-carved gold, 
tortoise-shell, or silver; or they imbibed the soothing pleasures of the 'intoxicating weed called tobacco mingled with liquid amber.' And while thus engaged a troop of almost phantom-like tumblers and jugglers gaily disported themselves before their wondering eyes. The after-dinner smoke, so dear to middle age, is a vestige of that civilisation which, before the onward march of the Spaniards, vanished like the mist of the morning. Our excellent guide through these realms of a shadowy past relates how the Aztecs would smoke after dinner to prepare for the siesta with as much regularity as an old Castilian does now. When dinner was over they rinsed the mouth with scented water, and an officer of the Court would then with much ceremony hand to the king his pipe. They smoked out of pipes made of polished and richly-gilt wood, inhaling the fragrant fumes of tobacco mixed with other aromatic herbs.

Girolamo Benzoni of Milan took a strong dislike to the Indian weed, and saw in it only a noxious plant whose fumes poisoned the pure breath of heaven. Like every European who visited the newly discovered countries of the West, he had his attention drawn to the herb the Indians loved, and in his History of the Nere World through some portion of which he travelled in $1642-45$, he describes the tobacco plant as growing in 'bushes, not very large, like reeds, that produce a leaf in shape like that of a walnut, though rather larger.' $\mathrm{He}$ says it is greatly esteemed by the natives and the slaves whom the Spaniards have brought from Ethiopia. He then describes the method of preparing it for smoking, which corresponds pretty nearly with the process in operation at the present day in America, and tells us that 'when the leaves are in season they pick them, tie them up in bundles, and suspend them near their fireplaces till they are very dry; 
and when they wish to use them, they take a leaf of their grain (maize) and putting one of the others into it they roll them round tightly together; then they set fire to one end, and putting the other end into the mouth they draw their breath up through it, wherefore the smoke goes into the mouth, the throat, the head, and they retain it as long as they can, for they find a pleasure in it; and so much do they fill themselves with this cruel smoke that they lose their reason. And there are some who take so much of it that they fall down as if they were dead, and remain the greater part of the day or night stupefied. Some men are found who are content with imbibing only enough of this smoke to make them giddy, and no more. See what a wicked and pestiferous poison from the devil this must be ! It has happened to me several times, that going through the provinces of Guatemala and Nicaragua, 1 have entered the house of an Indian who had taken this herb, which, in the Mexican language, is called tobacco, and immediately perceiving the sharp fetid smell of this truly diabolical and stinking smoke, I was obliged to go away in haste and seek some other place.' These strong words call forth the remark from his translator, Admiral Smith, that 'surely the royal author of the famous Counterblast must have seen this graphic and early description of a cigar!' Though in the same key, Benzoni's is but a feeble breath compared with the fulmination of our British Solomon against the 'lively image and pattern of hell,' or the 'Stygian fumes from the pit that is bottomless!' The fame of the Indian weed as a healer of the sick had not reached Europe when Benzoni published his travels through the Spanish possessions of the West, but its medicinal property had not escaped his acute observation. He gives a drawing of the medicine man putting three of 
his patients through a course of his tobacco treatment. The first is represented freely imbibing the fumes of tobacco, the second is just dropping his pipe, and himself off to sleep, and the third swings in a hammock attended by the doctor. Benzoni relates how in La Espanola and the adjacent islands sick men went to the place where the smoke was to be administered, and when they were thoroughly intoxicated by it, the cure was mostly effected. 'On returning to his senses the patient told a thousand stories of his having been at the council of the gods, and other high visions.'

And as to the origin of the plant, let the old chieftain of the Susquehanna tribe himself relate the story. It will merely be necessary to introduce him to the reader seated with his family, and a few braves gathered around him, listening to the words of a Swedish missionary, who expounds to them the creed of the Christian and the scriptural narrative of our first parents. The sermon over, the old chief, with easy grace and measured words, replies : 'What you have told us is very good, we thank you for coming so far to tell us those things you have heard from your mothers; in return we will tell you what we have heard from ours.

'In the beginning we had only flesh of animals to eat, and if they failed they starved. Two of our hunters having killed a deer and broiled part of it, saw a young woman descend from the clouds, and seat herself on a hill hard by. Said one to the other, "It is a spirit, perhaps, that has smelt our venison; let us offer some of it to her." They accordingly gave her the tongue. She was pleased with its flavour, and said, "Your kindness shall be rewarded, come here thirteen moons hence and you shall find it." They did so, and found where her right hand 


\section{ST NICOTINE}

had touched the ground maize growing, where her left hand had been, kidney-beans, and where she had sat they found tobacco!' 


\section{CHAPTER IV}

TOBACCO IN RELATION TO HEALTH AND CHARACTER

But oh, what witchcraft of a stronger kind, Or cause too deep for human search to find, Makes earth-born weeds imperial man enslave, Not little souls, but e'en the wise and brave?

ARBUCKLE.

Is smoking injurious to health? is an old and oftrepeated question which has agitated men's minds for fully three centuries, and out of which has grown a literature of peculiar interest, now signalised by royal Counterblasts and Papal Bulls, now rising in grateful pæans for the blessing conferred on weary humanity by the weed whose-

quiet spirit lulls the lab'ring brain,

Lures back to thought the flights of vacant mirth,

Consoles the mourner, soothes the couch of pain,

And breathes contentment round the humble hearth.

The utterances of the ex-Chancellor of the Exchequer, Sir Michael Hicks Beach, calling attention to the vast consumption of tobacco in these islands have given force and significance to the question, and naturally they suggest the further inquiry as to how we stand in the matter in relation to the past and to other civilised nations. On the threshold of the inquiry figures present themselves pointing directly to the conclusion that the British nation is spending upon the 
indulgence almost as much money as it does on the timehonoured staff of life, our daily bread. Certainly this aspect of the subject is somewhat startling. If the consumption of tobacco has grown to such a magnitude that it threatens to exceed that of wheat, then, clearly its consideration has become a question of national importance. It is the purpose of this chapter to lay before the reader some facts, statistical, botanical, and chemical, relating to this Indian weed which has done more to set good people by the ears than the whole world of Flora besides. To this end it will be necessary to ponder for a brief space on the skeleton forms and figures embalmed in State Blue Books.

Board of Trade returns are not what may be called recreative reading for leisure hours, but looked at goodnaturedly we soon come to regard them as we should sure-footed sumpter mules carrying the account books of commerce. A little searching and sifting among their packs, brings us upon figures which plainly tell the story of a steady, constant growth of the smoking habit, and that it has, within the last half-century, increased in strength more than two-fold. The ratio per head of the population, briefly stated, is as follows: In $184 \mathrm{I}$, when the population of Great Britain, and approximately of Ireland, was $26,700,000$, the quantity of tobacco cleared through the Custom-house for consumption in this kingdom was $23,096,28 \mathrm{I} \mathrm{lbs}$., or $13 \frac{3}{4}$ ounces for each inhabitant. In $186 \mathrm{I}$, with a population of $28,887,000$, the quantity of tobacco imported for home consumption amounted to $35,4 \times 3,846$ lbs., showing that its use had increased to $19 \frac{1}{2}$ ounces per head. Ten years later $(187 \mathrm{I}$ ) the proportion was 23 ounces for each person. And in 1891 the ratio per head had risen to 26 ounces; the quantity imported being 60,927,9 5 lbs. for a population of $38,000,000$. Put plainly, this increase 
of consumption may only mean that the man who, in $184 \mathrm{I}$, smoked only one pipe a day, in 189 I found himself so much better off that he could afford to smoke two.

Here, however, we come upon an important factor which, in calculating the weight of tobacco actually consumed, must be taken into account. Dr. Samuel Smiles, in the course of his investigations into the subject, discovered that in the process of manufacturing the leaf into the tobacco of commerce, water was added to the extent of 33 per cent. of the whole. The Statistical Office of the Customs has courteously furnished the writer of these lines with the further information that 'Raw tobacco when imported contains naturally $\mathbf{z} 3$ per cent. of moisture, but when it is cut up for sale, the total moisture must not exceed 33 per cent.'*

In estimating the weight of the weed actually consumed, it will be necessary to make an addition of 20 per cent. to the weight of the manufactured leaf imported. Since 189 I there has been a gradual increase in the quantity imported. In the financial year 1904-5 the total of all kinds amounted to $107,862,489 \mathrm{lbs}$. Of this $83,374,670 \mathrm{lbs}$. was retained for Home use, giving 1.95 lbs. per head of the population, and yielding a revenue to the national exchequer of $£$ i $3,184,767$.

As to the cost to the nation of this enormous quantity of tobacco, the official returns state that the declared value in I895 was, for manufactured $£_{1,256,3}{ }^{1} 3$, and for un

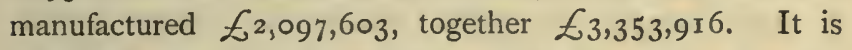
clear, however, that these figures can have little or no significance from the consumer's standpoint. Besides the

* In 1904 the maximum limit of moisture was fixed at 32 per cent. The moisture naturally present in the kinds now imported averages I 4 per cent. 
declared value and the Customs duty, there is to be taken into account the cost of manufacture and all the expenses incidental thereto; the retail dealer's profits, varying from about 20 per cent. in the poorer districts, to 75 per cent. in the best west-end shops. It may be mentioned also that the Customs duties vary, according to the kind of the tobacco imported, from $3 \mathrm{~s}$. $6 \mathrm{~d}$. to $5 \mathrm{~s}$. a pound weight, and that the price for which it is sold to the merchant, ranges from rs. 6d. per pound. No satisfactory data upon which a fair estimate can be based are to be found here. But, if an average price per ounce be taken, as a starting point, of the charge made by the tobacconist to the consumer of all the various kinds, from the patrician Havana to the plebeian 'rough-cut,' then we may arrive at a fairly reasonable estimate. Sixpence an ounce is rather below than above the average price paid for the weed. At this rate, however, a total annual expenditure is reached of $E_{3} \mathrm{I}, 304,108$. Then there is the almost endless variety of nick-nacks which accompany the use of tobacco, from the dhudeen and metal tobacco box of the Irish peasant, to the lordly, gold-mounted meerschaum and amber pipe, with cases, pouches, jars, pipe-racks, and all the paraphernalia the nicotian epicure demands for the use and adornment of his favourite indulgence. And how is the cost of these accessories to be obtained? If, out of the $40,000,000$ inhabiting these islands there should be $10,000,000$ smokers, each spending on an average $2 \mathrm{~s}$. $6 \mathrm{~d}$. only a year on these things, then would the annual outlay to the consumer mount up to the grand total of $£ 32,554$, ro8.

Again the writer has to acknowledge his indebtedness to the statistical branch of the Customs for the interesting information that the quantity of wheat consumed in this kingdom in 1895 was about $27,500,000$ quarters- 
$770,000,000 \mathrm{lbs}$. - and that the average value was $24 \mathrm{~s}$. a quarter, making a total value of $£ 33,000,000$. Thus we see how nearly the sum expended upon tobacco-smoking approaches to the sum spent upon wheat. Comparing the quantities of the two commodities we can only say, so much the better for the consumer of wheat, who obtains in weight about fifteen times more of bread than he could purchase of tobacco for the same sum-bearing in mind that wheat requires 45 per cent. of water for its conversion into bread. And herein lies the secret of the large consumption of tobacco: bread is so cheap, the poor man can afford to indulge in a little more of his comforter than he could formerly.

Commenting upon the vast increase in the consumption of tobacco, the Chancellor of the Exchequer was so mindful of the public interest as to give expression to his matured conviction that 'Everything spent on tobacco by those who have enough to eat is waste.' Acknowledging himself to be a non-smoker, and perhaps prejudiced, he would only appeal to smokers whether this was not waste: 'It is calculated,' said Sir Michael, 'by the Customs authorities that no less a value than $\mathscr{E}_{\mathrm{I}, 000,000}$ is literally thrown into the gutter in the shape of the ends of cigarettes and cigars. It is all the better for the revenue, but $I$ think it may be a subject of consideration for smokers.'

Looked at broadly, all such considerations are relativerelative to the numbers who smoke and to their ability to spend. Naturally we turn to our neigh bours across the silver streak and ask what they are doing; are they more frugal than we are in the use of the weed? Germany, always to the fore where painstaking and close attention to minutiæ is required, tells us that Holland uses the leaf at the rate of a trifle over 7 lbs. per head of her population; Austria, 
3.8 lbs.; Denmark, 3.7 lbs.; Switzerland, 3.3 lbs. ; Belgium, 3.2 lbs.; Germany, 3 lbs.; Sweden and Norway, each 2.3 lbs. ; France, 2.I lbs.; Italy, Russia, Spain may be classed together with a consumption of $1 \frac{1}{4} \mathrm{lb}$.; while the United States rises in the scale to $4 \frac{1}{2}$ lbs. for each inhabitant. There is much virtue in figures ; they give us the comforting assurance that after all we are not so bad as our neighbours by a pound or more, taking the average consumption of the leading nations of the world. So we may be permitted a little longer to smoke our pipe in peace undeterred by fearful forebodings of evil to come.

But then the whole world smokes, and what the whole world does must surely have some show of justification. It is estimated that two thousand millions of pounds weight are consumed every year, and that its money value far exceeds five hundred million pounds sterling; its production finds remunerative employment for countless thousands of families. In America alone the tobacco plantations cover an area of 400,000 acres, and in the labour of cultivation 40,000 persons win their daily bread. And what of the million of money wantonly thrown into the gutter every year? The smoker may well pause over his pipe and consider what this may really mean. One million pounds divided among forty million people would give sixpence to each. That every man, woman, and child should in this manner waste sixpence a year is doubtless much to be deplored; in the eyes of our excellent guardian of the public purse it is reprehensible. But is the whole of this money or money's worth really lost past recovery ? Investigations made at the instance of the Board of Inland Revenue concerning the fate that befalls cigar ends have been the means of revealing a curious aspect of our complex social system. Amid the crowd, the bustle and din of struggling 
humanity, glimpses may be caught of a quiet fellow-being plodding along the highways and byways of the great metropolis, with a bag slung over his shoulder, and his eyes fixed on the gutters intent upon picking up these unconsidered trifles, or wending his way to the side door of some hotel or hall where convivial souls do congregate of an evening, and there doing a little private business with the janitor, who pours into his bag these spoils of the night's revelry. And so it comes about that out of the gutters and waste places of the earth there ultimately return to the manufacturer the sorry remains of the once-treasured Indian weed. Many a young hopeful of slender purse hugs with pride his penny or twopenny cigar clad in a new coat, little dreaming of its having in a former existence shone, glow-worm like, in another sphere. Then there are 'fancy mixtures' made up for the pipe, enticingly scented with an odour unknown to the weed, and which, as if ashamed of the connection, vanishes in the burning, leaving not a trace behind, save wonder at what can have become of it, for the smoker gets none. And have we not always in view the lowly wayfarer along life's by-paths, whose feet have trodden thorny places and stumbled, maybe? He sees in the castaway an emblem of himself, and fraternally picks out of the gutter a little consolation for the buffets of the day; for tobacco has been aptly called the poor man's anodyne. And so life is rounded off with a smoke. Possibly thoughts such as these mingle with the smoker's reflections on the subject of waste to the consideration of which Sir Michael invited their attention. But the economic phase the question presents may be safely left to settle itself; for, after all, the cost of the indulgence is the merest trifle compared with the price paid for it in, say, Jacobean time, when paternal 
governments, out of a too tender regard for the interests of their loving subjects of mean estate, levied a tax upon tobacco which if converted into the coinage of the present day would be equivalent to six or seven times the sum for which it may now be purchàsed from the tobacconist. Curiously enough, another Michael (Drayton), well-nigh three hundred years ago (Polyolbion, I6I3), raised his voice more in sorrow than in anger against the extravagance of his times, as compared with the days.

Before the Indian weed so strongly was embrac't, Wherein such mighty summes we prodigally waste.

In this love of the weed, and the extravagant sums expended upon it, is to be found the key to Robert Burton's high praise and vigorous condemnation, uttered in one breath, of tobacco. As an example of Elizabethan nervous vigour the passage is worth quoting:

Tobacco! divine, rare, super-excellent tobacco! which goes far beyond all the panaceas, potable gold, and philosopher's stones; a sovereign remedy to all diseases; a virtuous herb, if it be well qualified, opportunely taken, and medicinally used; but as it is commonly abused by most men, who take it as tinkers do ale, 'tis a plague, a mischief, a violent purge of goods, lands, health, hellish, devilish, and damned tobacco, the ruin and overthrow of body and soul.

Democritus Junior did not mince matters, either in writing or when indulging in lusty banter with bargemen on the Thames.

Of more vital importance than the price paid for it is the consideration of its effects on health and character, and, if we would view the subjects in its larger bearings, on our 
physical and moral organisation it is obviously necessary that we should

Survey the whole nor seek slight faults to find Where nature moves, and rapture charms the mind.

At the outset, however, it cannot be too strongly emphasised that there is no question as to the baneful action of tobacco in any form on growing youths. Until the age of adolescence is safely passed, or till the riper age of one and twenty has been attained, there should be no thought of smoking. The tests and experiments of physiologists, the untrained observation of laymen, and the accumulated experience of civilised nations are agreed in this conclusion. Remarks pointing to the rapid growth of the smoking habit among youths were made by the Chancellor of the Exchequer in his recent Budget speech, where, commenting upon the augmented revenue from tobacco, he said it was mainly due to the vast consumption of cigarettes, which were specially attractive to our youthful population. 'I am told,' Sir Michael added, 'of one manufacturer who makes two millions of cigarettes a day who hardly made any a few years ago.'

Every-day observation bears out the statement that the cigarette is the chosen smoke of youths. Go where we will, in crowded streets or country lanes, boys of the tender age of from nine or ten years upwards are almost constantly met with, smoking paper cigarettes, who were they better advised would prefer toffy, as was the case a few years ago. Surely every one knows that children cannot go on smoking tobacco with impunity, without, in fact, doing themselves life-long injury. Since parents are too heedless of their children's welfare to prevent them from pursuing a practice the inevitable results of which will, by-and-by, appear in 
stunted, weakly growth and the train of evil which follow on deranged nerve-tissue, it would seem to be no more than humane that the Legislature should step in and prohibit the sale of tobacco in any form to children under the age of say, sixteen. Already some of the states of North America have instituted penal enactments for the protection of children against the indulgence, which to them is pernicious.

But what shall be said of the young man whose downy lip bears testimony to his approaching majority-the age when life is a romance and the future aglow with roseate dreams? He knows himself to be the hope and pride of his parents, that in him is centred all sorts of brilliant possibilities. Nothing could be more fitting, he thinks, than that he should proclaim to the world that he is now a man by airing the park with his first cigar. And who so heartless as to say him nay? He now becomes confidential with the tobacconist, and learns from him the names of the choicest brands, as the Vegueras, the kind specially prepared for the Prince of Wales, selected from the finest growths of the plant raised in the Veulto Abajo district of Cuba, as well as the outer signs of many another rich and rare leaf from the gardens of the Queen of the Antilles, or from the plantations of the Indian Archipelago. By-and-by his whole energies will be devoted to the service of his king and country, doing the world's roughest work away out in the wilds of Africa, or administering justice, it may be, among lawless tribes in Imperial India ; and many a time, when belated on a desolate track with nothing to cover him but a blanket borrowed from his trusty peon, he will draw from the recesses of a deep pocket or knapsack a homely briar-root with more real pleasure than he ever felt when smoking the choicest cigar on the Mall. 
The temperament of each individual or of a race is an important factor in a judicious consideration of the subject ; it opens out a field of inquiry of no ordinary interest, more particularly as regards eastern nations. By temperament physiologists mean certain physical and mental characteristics arising from the predominant humours of the body. Galen in the second century was perhaps the first to employ the term to designate, according to the teachings of the old school, the condition of the four elements of the body-the blood, choler, phlegm, gall-and the varying combinations of these, recognised to-day as the sanguine, lymphatic, nervous, or bilious temperaments. Interest in this aspect of the subject is heightened when we consider the marvellous effect the consumption of tobacco has had on races inhabiting Western Asia. Speaking on this curious point in the Indian Section of the Imperial Institute in February, 1896, Sir George Birdwood called attention to the change wrought in the character of the Turks by its use. He remarked that

in ancient times the Scythians were a ceaseless scourge to the neighbouring nations; that they were referred to by the prophet Jeremiah as a 'seething caldron,' ever boiling over in fierce and cruel eruptions from the North. Where are they now? They have become the modern Turks; and the magic which changed them from restless, destructive nomads into the quiet and only too conservative sedentary Turks, Von Moltke tells us in his Letters from Turkey was none other than the acquired American habit of smoking tobacco.

Coming from so profound an observer of men as the great German strategist, this testimony to the influence of the Indian weed on human character is to be accepted as a valuable contribution to our knowledge. And yet, viewed in the light of recent events in Turkey, the marvellous 
transformation mentioned would seem to be hardly yet completed. Besides, may not other influences tending to modify the character of the Turks be found in their four centuries of intermarriage with tribes of a less turbulent disposition, as with Persians and Circassians, than the fiery, stubborn mountaineers from whom they had descended? It seems but reasonable to think so. Let us hasten, however, to note that other distinguished travellers in Turkey speak to the same effect, and that they, too, attribute the change to the sobering and soothing action of tobacco upon them. Dr. Madden, whose Travels in Turkey and Egypt were published in 1829 , says (i. 16) that

the pleasure the Turks had in the reverie consequent on the indulgence in the pipe consisted in a contemporary annihilation of thought. The people really cease to think when they have been long smoking. I have asked Turks repeatedly what they have been thinking of during their long reveries, and they replied 'Of nothing.' I could not remind them of a single idea having occupied their minds; and in the consideration of the Turkish character there is no more curious circumstance connected with their moral condition.

Further testimony to Nicotiana's benign sway over human character is borne by Mr. E. W. Lane, the talented translator of the Avabian Nights and author of the Manners and Customs of the Modern Egyptians. In this latter work Mr. Lane says that

in the character of the Turks and Arabs who have become addicted to its use it has induced considerable changes, particularly rendering them more inactive than they were in earlier times, leading them to waste over the pipe many hours which might be more profitably employed; but it has had another and better effect-that of superseding in a great 
measure the use of wine, which, to say the least, is very injurious to the health of the inhabitants of hot climates. . . It may further be remarked in the way of apology for the pipe, as employed by the Turks and Arabs, that the mild kinds of tobacco generally used by them have a gentle effect ; they calm the nervous system, and, instead of stupefying, sharpen the intellect.

He next pays a high tribute to the Oriental method of smoking, and assures the reader that the pleasures of Eastern society are considerably enhanced by the use of the pipe, adding. 'It affords the peasant, too, a cheap and sober refreshment, and probably often restrains him from less innocent indulgences.' Mr. Layard and Mr. Crawfurd, whose large experience of Eastern peoples is known to the world, have each recorded his opinion to the effect that the use of tobacco has contributed very much towards the present sobriety of Asiatics. The presence of an array of witnesses such as these to the power of the pipe to subdue the savage breast naturally suggests the thought of a new field of operations for its use. That laudable organisation, the Peace Society, which seeks to combat man's militant instincts by such persuasions as fall short of the shillelagh, ought certainly to find in the Indian's peacepipe with a well-filled tobacco-pouch a coadjutor for the propagation of its amiable doctrines; at any rate, a pioneer that would prepare the soil for the seed and the advent of the millennium. Lord Clarendon, when Minister of Foreign Affairs, used to excuse his room reeking with the fumes of tobacco by declaring that diplomacy itself was a mere question of the judicious application of tobacco between opposing plenipotentiaries. The pipe, indeed, has always been recognised as a good diplomatist. If you want time to consider well before committing yourself to an 
answer you find that the pipe won't draw, though you puff and puff; then, having gained time and cleared your thoughts, the pipe mends, a cloud is formed, and out of chaos comes light, and now you are ready with your argument, though you may begin with, 'your pardon, friend, but what were we talking about?' If diplomacy can be soothed and led out of thorny paths into pleasant ways, then assuredly a useful career awaits the weed in the House, where the magic of its suasive breath would subdue a bellicose Parliament into easy complaisance, and so confer an inestimable blessing on a weary Legislature.

But it would be well to take a closer view of this marvellous weed which enters so largely into our domestic economy, dipping into our purses, affecting in some measure our health and habits, in a way, too, that leads people to think that surely a mischief-loving Puck lurks among its alluring leaves, delighting to send its votaries, some into dreams of Elysium, others into visions of-another place. Nicotiana, the name science has bestowed on the plant in recognition of the services of Jean Nicot in spreading a knowledge of it over Europe, more particularly as regards its supposed medicinal properties, is a member of a large and varied family of the natural order Solanace, one of the largest genera, containing about 900 species. The whole family is more or less suspicious; some members are decidedly bad, as, for example, the deadly nightshade, henbane, and mandrake, evil names which startle the timorous and all self-respecting people. Relief, however, comes, and confidence is restored, when we learn that linked with Nicotiana as twin sister is our old and esteemed favourite the potato, whose humble services to hungry humanity are incalculable. Yet out of the leaves and fruit of this useful and innocent member of the family chemists 
extract a deadly poison called solanine, which they describe as an acrid narcotic poison, two grains of which given to a rabbit caused paralysis of the posterior extremities, and death in two hours. Traces of this poison are also found in healthy tubers. And yet nobody was ever poisoned by eating potatoes; far from this, many in times of scarcity have died for want of them. Considering these things, smokers may possibly comfort themselves with the thought that tobacco does not stand alone in evil repute, that even a vegetable which enters so largely into the composition of humanity as does the potato contains a portion-an infinitestimal portion it is true, but still some portion-of the element of evil which seems to permeate more or less all things earthly. But let them reserve their judgment until the evidence of the chemist has been heard. It may be urged, too, that the highly prized virtues of the tomato, a family connection, might be taken into account in estimating the sins of the shady ones. The love-apple of Eris, far from creating discord, gives unalloyed pleasure, affording the epicure a gastronomic delight.

The genus Nicotiana comprises upwards of forty species, of which five only are cultivated for tobacco, and, of these, three stand out conspicuously as the best and most favoured ones of commerce. In botany they are designated:-(I) Nicotiana Tabacum; (2) N. rustica; (3) N. persica. They differ one from another chiefly in the degree of thickness of the midrib and fibres, and in the evenness of the leaves, which are usually hairy and somewhat clammy feeling. The first mentioned is the typical tobacco plant of America, whose home is still where Raleigh's first colonists to the New World found it, in Virginia. From its leaves is prepared the great bulk of the tobacco consumed in this country, as well as in America. It is a 
strong, handsome, flowering perennial, growing in latitudes varying from about $40^{\circ} \mathrm{Fahr}$. to the tropics. And a most voracious feeder, it quickly exhausts the richest soils, yet it is so hardy that it will thrive in almost any soil and anywhere. In tropical lands, however, particularly such as are light, dry, and rich in potash, it flourishes most luxuriantly, and attains its fullest and healthiest development, sometimes rising to the grand altitude of $r_{5}$ feet, though 6 feet is the usual limit of its upward growth. The root is large, long, and fibrous; the stalk or central stem is erect, strong, of the thickness of a man's wrist, and hairy; towards the top it divides into branches. The leaves embrace the stem from the base; they are large, symmetrical, lanceolated, and of a pale-green colour, measuring usually 2 feet by I 8 inches. From the summit of the branching stalks clusters of rose-coloured flowers are produced of a bellshape, the segment of the corolla being tapering and pointed; the seeds are contained in long sharp-pointed pods, and are so small that in one ounce no fewer than I0०, 000 have been counted.

Next in order of importance in a commercial sense ranks the Syrian plant, $N$. rustica. It is nevertheless a native of America which transplantation into Syrian soil has greatly improved in all those qualities which commend themselves to delicate smokers. It differs from its sister plant of Virginia chiefly in its dwarf-like stature, for it seldom attains a higher growth than three or four feet, and its leaves are not so symmetrical; they are of an ovate shape, and are not attached to the centre stem, but issue from the branching stalks, which in the season bear green flowers; the segment of the corolla is rounded. This, too, is a hardy plant, flourishes well in almost any latitude, and ripens earlier than the N. Tabacum. For some years back it has been 
largely cultivated in Germany, Holland, and the countries bordering on the Mediterranean; indeed, it at one time flourished rapaciously in our own fields, flowering from midsummer to Michaelmas. From its leaves are obtained, under the varying conditions of soil and climate, the kinds of tobacco vended to the consumer under the names of Turkish, Syrian, and Latakia. And on account of its retaining much of its primitive colour all through the process of drying and manufacture it is recognised in commerce as 'green tobacco.'

In the third variety we have the beautiful white flowering Persian plant, from whose oblong stem-leaves is prepared the famous Shiraz tobacco, $N$. persica. It is now recognised as a native of Persia, though its original home is undoubtedly across the Atlantic. Being slow to ignite, this aromatic weed does not lend itself readily to the cigar; but surely the difficulty might be overcome by using an Indian wrapper. The planters of Dindigul, or, as Sir W. W. Hunter gives the name in the Imperial Gazetteer of India, Dindu-Kal (Rock of Dindu), are now sending to Europe large quantities of their fine flavoured tobacco leaf which would form a very good wrapper for this fragrant but slowburning weed.

There is a fourth variety named Nicotiana Finis, which has found much favour in the private gardens of England. It is not so symmetrical as those just mentioned, its leaves are small, widely separated, in fact, rather straggling; but under the training of a skilled gardener it is made to assume a bushy form. Its chief attraction is found in the delicate white flowers which it produces; these during the daytime droop, but at sundown they generally assume an erect posture and become firm, then the petals expand and the flower emits a delicious perfume, sweeter far than jessamine. 
In the tobacco plant English florists and gardeners have found an accessory for filling up vacant spots in their shrubberies with good effect; and the siae-beds along a carriage drive, or the shelves in a greenhouse, can be pleasingly diversified by selections from the varying kinds the genus Nicotiana presents. As an ornamental flowering plant it is certainly worthy of a place among the many charming indigenous and exotic shrubs which nowadays adorn private grounds. Then its uses either as a fumigator or as a wash are such as all experienced gardeners know well how to appreciate; in either form it is a powerful prophylactic, readily destroying insect pests and the germs of blight.

Let us now pass into the domain of the chemist and view for a while the operations of this modern magician as he summons the genii of the Indian weed to appear before him in all their naked deformity, and compels them to yield up their secrets. There is no poetry in the chemist's crucible; imagination fails to lend a transient charm to the grim constituents of the bewitching leaf. Here, in his silent retreat, the analyst weighs and measures, tests and resolves into their original elements whatever things, foul or fair, come into his hands. He weighs a pound of the prepared leaves, steeps them in water, and subjects them to distilation; presently there rises to the surface a volatile, fatty oil which congeals and floats. It has the odour of tobacco and is bitter to the tongue; on the mouth and throat it produces a sensation similar to that caused by long-continued smoking. Taking a minute particle on the point of a needle he swallows it, and immediately experiences a feeling of giddiness, nausea, and an inclination to vomit. And yet the quantity obtained of this evil thing from the pound of leaves is barely two grains. Now he adds a little 
sulphuric acid to the water, and distils with quicklime; soon there is dislodged from the hidden cells of the leaves a small quantity of a volatile, oily, colourless, alkaline fluid, the prince of the genii-nicotine. The odour of an old clay pipe grown black with age hangs about it: it is acrid, burning narcotic, and scarcely less poisonous than prussic acid, a single drop having the power to kill a dog. It boils at a temperature of $482^{\circ}$ Fahr., and rises into vapour at a point below that of burning tobacco, consequently it is always present in the smoke. Evaporating one drop of this subtle essence you are at once seized with a feeling of suffocation, and experience difficulty in breathing. Distilled alone in a retort yet another element is called up of an oily nature, which resembles in its chief characteristics an oil obtained by a similar process from the leaves of the foxglove (Digitalis purpurea). This also is acrid and poisonous ; one drop applied to the tongue of a cat brought on convulsions, and, in two minutes, death. All these evil things the chemist tells us dwell in the heart of the Indian herb, and, mingling with other unseen elements, lure men on to their fate. In the mystical glare of his laboratory there looms into shape before our mental vision the spectral form of the King of Denmark, in Hamlet, telling of the dark deeds done

With juice of cursed hebenon in a vial, And in the porches of my ears did pour The leprous distilment; whose effect Holds such an enmity with blood of man That swift as quicksilver it courses through The natural gates and alleys of the body.*

* Possibly hebenon is here employed for henbane, a name sometimes applied to tobacco by writers in Jacobean times. William Strachey, in his Historie of Travaile into Virginia 
And memory recalls the case of the Comte de Bocarme who was executed at Mons, in $185 \mathrm{r}$, for poisoning his brotherin-law with nicotine, in order to obtain reversion of his property. The simple though crafty Hottentot, too, finds in the juice of tobacco a potent agent wherewith he can rid himself of the snake that, unbidden, glides into his kraal. Under the influence of one drop the reptile dies as instantly as if struck by an electric spark.

A distinguished physician and man of science, Sir B. W. Richardson, has tested the tobacco leaf and all its component parts with a thoroughness which puts to flight all doubts as to what it is 'men put into their mouths to take away their brains.' The chief results of his experiments may be briefly summarised. Although evident differences prevail in respect to the products arising from different cigars, different tobacco, and different pipes, there are certain substances common to all varieties of tobaccosmoke. Firstly, in all tobacco-smoke there is a certain amount of watery vapour which can be separated from it. Secondly, a small quantity of free carbon is always present; it is to the presence of this constituent that the blue colour of tobacco is due. It is this carbon which in confirmed and inveterate smokers settles on the back part of the throat and on the lining of the membrane of the bronchial tubes, creating often a copious secretion which it discolours.

Britannica (1610), speaks of the tobacco-plant as 'like to henbane.' John Gerard in his description of the plant calls it ' henbane of Peru.' French writers of the same period had an unlimited vocabulary for tobacco, and among their names for it may be found 'Peruvian henbane' (jusquiame de Peru). If this view be admitted, then we have in 'hebenon' the only reference to tobacco the whole of Shakespeare's works contain. 
Thirdly, the presence of ammonia can be detected in small quantity, and this gives to the smoke an alkaline reaction that bites the tongue after long smoking; it is the ammonia that makes the tonsils and throat of the smoker so dry, and induces him to quaff as he smokes, and that partly excites the salivary glands to secrete so freely. This element also exerts an influence on the blood. Fourthly, the test of lime-water applied to the leaf, shows the presence of carbonic acid. In the smoke the quantity differs considerably in different kinds of tobacco; to the action of this constituent Sir B. W. Richardson traces the sleepiness, lassitude, and headache which follow upon prolonged indulgence of the pipe. Fifthly, the smoke of tobacco yields a product having an oily appearance and possessing poisonous properties; this is commonly known as nicotine, or oil of tobacco, which on further analysis is found to contain three substances, namely, a fluid alkoloid (the nicotine of the chemist), a volatile substance, having an empyreumatic odour, and an extract of a dark resinous character, of a bitter taste. From this comes the smell peculiar to stale tobacco which hangs so long about the clothing of habitual smokers-if the smell be from good Eastern-grown tobacco many persons think it wholesome. It is nevertheless this extract which creates in those unaccustomed to its use a feeling akin to sea-sickness. Hence it appears that the more common effects are due to the carbonic acid and ammonia liberated in the process of smoking, while the rarer and more severe symptoms are due to the nicotine, the empyreumatic substance, and the resin.

As to the effects of tobacco-smoking upon the human body Sir Benjamin Richardson would appear to see no reason for thinking that it can produce any organic change, though it may induce various functional disturbances if 
arried to excess. These are such as all young smokers cexperience more or less severely, according to their temperament and the quality or strength of the tobacco they use. There can be no question that the first attempt at smoking reveals phenomena which plainly show that to become one of the initiated in the service of Nicotina a certain ordeal must be passed through if the novice would rank among her votaries. It may be of use to remark that the stronger kinds of tobacco are the products of the Virginian and Kentucky plantations; French tobacco too is quite as strong, they contain from six to eight per cent. of nicotine; Maryland and Havanna tobaccos, also those of the Levant, generally average two per cent., while the products of Sumatra and China barely contain one per cent. of nicotine. The general conclusion Sir Benjamin Richardson deduces from his experiments is such as might be fairly expected from an eminent physician of large experience, unbiassed by prejudice. In this judicial sense he remarks that tobacco 'is innocuous as compared with alcohol; it does infinitely less harm than opium, it is in no sense worse than tea, and by the side of high living altogether it compares most favourably.' But on the question of youths smoking he speaks most decisively against even the smallest indulgence in tobacco before the system is matured. His words are: "With boys the habit is as injurious and wrong as it is disgusting. The early "piper" loses his growth, becomes hoarse, effete, lazy, and stunted.'

The late Professor Johnston, of Durham, gave his attention to the subject, and in the eminently useful work on the Chemistry of Common Life he minutely describes the results he obtained from a careful analysis of tobacco leaves. These in all essential particulars are such as have 
already been mentioned. Although he points out the highly poisonous nature of some of the constituents of tobacco, he yet speaks regretfully of his inability to derive from smoking the soothing pleasures mentioned by others, particularly by Dr. Pereira, who remarking on its tranquillizing effects when moderately indulged in, says that 'it is because of these effects that it is so much admired and adopted by all classes of society, and by all nations, civilised and barbarous.' Mr. Johnston continues :

Were it possible amid the teasing, paltry cares, as well as the more poignant griefs of life, to find a mere material soother and tranquillizer productive of no evil after-effects and accessible alike to all - to the desolate and the outcast equally with him who is rich in a happy home and the felicity of sympathising friends-who so heartless as to wonder or regret that millions of the world-chaffed should flee to it for solace? I confess, however, that in tobacco I have never found this soothing effect. This no doubt is constitutional, for I cannot presume to ignore the united testimony of the millions of mankind who assert from their own experience that it does produce such effects.

He draws attention to the effects of tobacco on the Turks, and speaking of the drowsy reverie they fall into under its influence, asks if it is really a peculiarity of the Turkish temperament that makes tobacco act upon them as it does, sending the body to sleep while the mind is alive and awake.

That this is not its general action in Europe (he remarks) the study of almost every German writer can testify. With the constant pipe diffusing its beloved aroma around him the German philosopher works out the profoundest of his results of thought. He thinks and dreams, and dreams and thinks, alternately; but while his body is soothed and stilled, his 
mind is ever awake. From what I have heard such men say, I could almost fancy they had in practice discovered a way of liberating the mind from the trammels of the body, and thus giving it a freer range and more undisturbed liberty of action. I regret that I have never found it act so upon myself.

These reflections of the sympathetic Professor may be very grateful to the habitual smoker, who influenced by a natural feeling of attachment, looks lovingly on his pipe and pouch, as he would on old friends grown dearer with time; the older and more worn the closer he clings to them, till by-and-by he talks to them as would primitive man to his fetish. But this amiable weakness needs to be looked firmly in the face, and if it cannot bear scrutiny, if the indulgence be found hurtful to body or mind, it must go; thrown out of the window if need be, with a resolve not to go out and look for it, to restore it to its old niche, though the old pouch may contain Mr. J. M. Barrie's beloved, Arcadia Mixture.

Undoubtedly we have among us, and have had in England since the days when Raleigh introduced the 'Indian's herb' into the royal palace and made it agreeable to his queen and fashionable everywhere, some remarkable examples of great smokers occupying the highest positions in the domain of intellect. Instances crowd the memory. The tall, dark figure of Thomas Hobbes of Malmesbury presents itself, he whose Leviathan and other philosophical works stirred into activity the intellect of Europe, and who attained the ripe age of ninety-two. Sir Isaac Newton smoked, even in the presence of the lady who honoured him with well-meant attentions. Seated one day quietly by his side, happy in anticipation of what the future might bring forth, Sir Isaac suddenly seized her hand-now the blissful moment had arrived!-but, instead of tenderly 
pressing it within his own, he probed her little finger into the bowl of his pipe to remove some obstruction. The story told by Sir David Brewster points a moral-ladies should be chary of lavishing their affection on philosophers, they are so very absent-minded. Divinity furnishes a host of devotees to the pipe. Leading the throng are Dr. Henry Aldrich, of Christ Church, Oxford ; Dr. Parr, whose Greek was the admiration of ripe scholars and the terror of little boys; who overwhelmed his friends with torrents of eloquence and clouds of tobacco-smoke; Robert Hall, England's greatest pulpit orator, and many another divine burned incense continually at the shrine of Nicotiana; while towering in the forefront of the great tobacco-smokerof the Victorian age are the figures of Carlyle and Tennyson. But these illustrious examples of great tobacco smokers are, in respect to the whole community, altogether exceptional, and may be regarded as having no more bearing on any general rule applicable to all men than had their individual capacity for imbibing, say, 'sweet waters.' It may be observed, however, that those who pass severe censure on the smoking habit seem to overlook the fact that men do not eat or drink tobacco; that the prudent smoker is quite contented if its ambient fumes gently float about him, regaling his olfactory sense. It can never satisfy reasonable inquiry to be told that deadly results follow the administration, not of the smoke, but of a single drop of the essential oil of tobacco to a dog, that dies of old age at fifteen years; or to a rabbit, that breeds seven times a year and dies at the age of five. Far above theorising there is the teaching of experience, and if each would-be smoker will in this, as in other things, be guided by this unfailing monitor, and act upon the dictates of common sense, no harm will come to him. 
There are people of so gloomy a temperament that they would not let a man cultivate a flower-garden or listen to the songs of birds on the Sabbath; who look upon music as a sensuous indulgence, and reading as idleness. To these we have nothing to say; it is their misfortune to think and feel so. Stripping the argument of the puerilities and exaggerations of prejudice, let us recognise the broad fact that men of every nation and in every climate do smoke; a fact that is universal needs no apology.

The prophylactic properties of tobacco will be considered from an historical point of view in the next chapter, headed, 'The Use and Abuse of Tobacco.'

This chapter first appeared in The Nineteenth Century for May 1897. Mr. W. T. Stead, commenting upon it in his Review of Reviews, agreed with the writer's firm stand against juvenile smoking, and expressed the opinion that ere long an act of Parliament would be entered in the Statute Book prohibiting the sale of tobacco to youths under the age of 16 . Unavailing efforts to this end were subsequently made by private members of the House of Commons. At last the Legislature has taken up the subject, and under the tactful conduct of the measure of Mr. Herbert Samuel, the UnderSecretary for the Home Office, a Bill has passed the third reading making the sale of cigarettes to children illegal. This step in the right direction will have the effect of awakening public attention to the subject, and of stirring up parents to a more watchful supervision over their children's habits. 


\section{CHAPTER V}

THE USE AND ABUSE OF TOBACCO

Ye hot, ye cold, ye Rheumatick draw nigh; In this rich leafe a sovereign dose doth lie. We'll cure ye all; Physick ye need not want, Here, 'tis i' th' gummy inside of a plant. $-1670$.

THough differences of temperament may not allow everyone the mild indulgence of the pipe, all are interested in learning that in the leaves of the Indian's weed dwells a friendly genius ready to protect us from the virulent attacks of the myriad host of invisible life which floats around us, in some cases infecting the air we breathe, the food we eat, and the water we drink. This assurance comes to us from the bacteriologist, whose experiments conducted under the microscope, demonstrate that contact with the smoke of tobacco destroys the vitality of microbes. Especially comforting is it to know this at the season of the year when the air liss heavily upon the land.

Here, then, we come upon ground interesting alike to the smoker and the non-smoker, for both will agree that it is infinitely better to let the weed spread its wings on the blast and breathe in the face of the foe than to go unprotected through unwholesome air laden, it may be, with noxious germs. 
It is also gratifying to learn that our forefathers, in whose wisdom all right-minded people, of course, fondly believe, were not wholly wrong in their estimate of the manifold virtues of their beloved herb. With the largeness of faith which belongs equally to the infancy of research and the springtime of life, they believed with the implicit faith of childhood in its all-healing powers. And the learned in the secrets of Nature proclaimed to suffering humanity that out of the heart of the New World had come a remedy for all the ills that flesh is heir to. But if facts grew too strong for faith to grapple with, and overthrew their Dagon, this one consolation remains to testify to their just appreciation of the weed, namely, that it can, and does, destroy contagious germs.

Early in the seventeenth century, physicians at home and abroad had observed a connection between the use of tobacco and freedom from the dread pestilence which at times swept over the land. Doctors Gardiner and Lewis, Thorius and Diemerbroeck, Hoffman and Willis have left records of their experience of cases where tobacco proved to be efficacious, administered either in fume or liquor, lotions or unguents. No doubt their treatment was somewhat crude, and their concoctions (marvels of simplicity) were not always successful, and, needless to say, that modern therapeutics takes no account of their remedies. But their discovery that tobacco was destructive of insect life on animals as well as on vegetables, that it cleansed old wounds and sores and suffered them to heal 'comfortably,' surely redeems them from a multidude of sins committed in the name of tobacco.

Glancing back to the early records of its advent in Europe we come upon Liebault in 1570 discoursing pleasantly on the marvellous virtues of the herb, and learn 
of him that it owes its introduction into the fashionable world to Jean Nicot. He says, 'Although it be not long since it hath been known in France, notwithstanding, deserveth palm and price, and among all other medicinable herbs it deserveth to stand in the front rank, by reason of its singular virtues, and, as it were, almost to be held in admiration, as hereafter you shall understand . . . The herb is called Nicotiane, of the name of him that gave the first intelligence thereof into this realm-as many other plants have taken their name from certain Greeks and Romans, who, having been in strange countries for service of their commonweals, have brought into their countries many plants which were before unknown. Some have called it the Queen's herb, because it was first sent to her, as hereafter shall be declared by the gentleman that was the first inventor of it, and since has by her been given to divers people for to sow, whereby it might be planted in the land. Others have named it the Grand Prior's herb, for that he caused it to multiply in France, more than any other, and for the great reverence that he bears to his herb, because of the divine effects therein contained. Notwithstanding, it is better to name it Nicotiane, the name of him that sent it into France, first, to the end that he may have the honour thereof, according to his desert, for that he hath enriched our country with so singular an herb.'

Jean Nicot, Lord of Villemain, and Master of the Requests of the French King's household, was sent as ambassador to the Portuguese Court in 1559 , remaining there until $\mathrm{r}_{56} 6 \mathrm{r}$. On the occasion of his visiting the state prisons of Lisbon, the keeper, being a gentleman, as Liebault states, presented him with specimens of a strange herb, which had just arrived in Port from Florida, shipped by a Flemish merchant. Nicot's curiosity was aroused and he took an 
early opportunity of purchasing from the merchant a quantity of the prepared leaves, and some seeds of the plant. Learning from him what use the Indians made of the weed, and their manner of smoking it, he began to experiment, first upon himself (as all good practitioners should do) and liking it, he caused some of the seeds to be sown in his garden, where to his great joy they grew and multiplied exceedingly. There can hardly be a doubt that Nicot had been told by the merchant that the Indians expressed a juice from the leaves with which they cured the wounds received in battle, and that he had made this known to his domestics. For Liebault says that the Lord Ambassador was one day advertised of a young man of kin to his page who had made assay of the herb, bruised and in liquor, upon an ulcer he had upon his cheek near unto the nose, coming of a Noli me tangere, which began to take root already at the gristle of the nose, wherewith he found himself marvellously eased. Whereupon Nicot caused the said young man to be brought before him, and after a minute inspection he ordered the sufferer to continue the treatment eight or ten days longer. Nicot now hurried off to the King of Portugal's physician and informed him of the case, and together they watched the progress of the cure. By the end of ten days the physician was enabled to certify that the Noli me tangere was 'utterly extinguished' and the face 'comfortably healed.' Shortly afterwards Nicot's cook almost cut off his thumb with a great chopping knife, and he too, flew to the new remedy for relief, and after five or six dressings was likewise comfortably healed. A captain presented his son to the Lord Amadassador and besought him to exert his healing art upon the boy, who was grievously afflicted with the King's evil. And unto him was assay made of the liquor of the herb, and again its 
curative powers were asserted in the complete renoval of the disease. Next came a gentleman from the fields, craving the Lord Ambassador to cure him of a wound in his leg, which for a space of two years had tortured him and rendered the limb useless. Nicot, filled with generous enthusiasm, readily acceded to his appeal, and lotions and unguents were prepared for him, with instructions how to apply them. In ten days' time he again presented himself, and with overflowing gratitude declared that the ulcer had disappeared, and that he had now perfect use of his leg. Many other similar Noli me tangeve cases and their comfortable cure are recorded by Liebault and Monardes. News of the potent influence of the weed, now commonly called the Ambassador's herb, over bodily infirmity spread with amazing rapidity, and out of every nook and corner of the kingdom there flocked to the Ambassador sufferers of all sorts and conditions, praying to be healed of their Noli me tangeve. Nicot's garden was now a centre of attraction for fashionable loungers: his house had already become an infirmary; and great was the rejoicing when the maimed, the sick, and the wounded threw away their crutches, sound of body and full of faith. From the recital whereof it plainly appears that though names may change, poor humanity remains pretty much what it was in the beginning, and none wax so fat in fame or fortune as those who minister to its weaknesses.

But Nicot's work as a healer of the sick with the Indian weed was not yet completed; there were patients at home demanding his immediate attention. Hearing that Lady Montague was dying at St. Germains of an ulcer 'bred in the breast,' which of course was none other than our old friend Noli me tangeve in the form of cancer, and for which no remedy could ever be found, though the Countess 
of Russe had consulted on her friend's behalf the most eminent physicians of the realm, Nicot, with commendable promptitude, despatched to the king a quantity of the weed, sending therewith precise instructions how to prepare and administer it. With this first instalment he wrote describing it as having a peculiarly pleasant taste, and oddly enough, he bestowed upon it his own name, saying, 'Nicotiane est une espèce d'herbe de vertu admirable - pour guérir toutes ulcères et autre tels accidents au corps humain.' This letter is said to be still preserved in the Chateau Belem. To the Queen Mother he presented seeds of the plant which she caused to be sown in the royal gardens. This wondrous product of the new-found world, where all was strange and clothed in the garb of mystery, created a lively interest in France. But Europe had hardly yet emerged from the glamour of the Dark Ages, when every important event was governed by invisible agencies, and magic alone could explain the inexplicable. Catharine de Medici would secretly consult her magician before entering upon any of her numerous dark designs. Parenthetically it may be mentioned that George Buchanan, the Scotch philosopher and tutor to our James I., had so strong an aversion to Catharine de Medici that in one of his Latin epigrams, where he alludes to tobacco being called d'herbe Medici, he warns all who value their health to shun the herb, not that in itself it is hurtful, but being called by so vile a name it must needs become poisonous. A single instance may suffice to indicate the kind of interest the weed on its first introduction into France awakened in the French court. Gathered round the queen's table are some of the brightest wits of the gay capital, discussing with eager curiosity the marvellous story told of the Indian's herb in the despatch just received 
from Nicot. Listening to these things the Comte de Jarnac felt irresistibly impelled to do something significant of the ocassion, and springing from his seat he hastened to the house of his dearest friend to repeat the story. His friend was 'short-breathed,' suffering indeed from a severe attack of asthma. Unfolding the packet containing his share of the precious herb, Jarnac directed an attendant to distil it; this done, he added to the liquor some euphrasy (eyebright). Then presenting the decoction to the patient, he explained to him with the eloquence born of a new faith that the spirit of the herb would enter into his own and would assuredly expel the demon of asthma. Thus urged and entreated, the sufferer swallowed the potation, and wonderful to relate, if we are to believe the zealous chronicler, the man who but a little while before was gasping for breath was now comfortably healed!

Clearly then tobacco owes its introduction into the highest ranks of European society to its credentials as a healer of the sick. Immediately after France had received her first instalment, along with Nicot's laudatory account of its marvellous virtues, Italy obtained the herb direct from the hands of Cardinal Santa Croce on his return from his nunciature in Spain, and for years it bore in his honour the name of Erba Santa Croce. Castro Duranti celebrated the event in latin verses, wherein he ascribes to the Indian's herb the efficacy of a charm over every malady, and extols the cardinal for his service in bringing it, coupling his name with his distinguished ancestor, who brought to Rome a portion of the true cross. He assures the reader that their services rightly considered

Procure, as much as mortal man can do, The welfare of our souls and bodies too. 
Tidings of the pleasing delusion of tobacco's wonderful curative properties reached these shores towards the close of the sixteenth century, when the pipe was already installed in almost every chimney-nook. Needless to say that lovers of the weed received the intelligence with warmth, and held to the new belief with a steadfastness nothing could shake. Some of England's foremost poets and dramatists signalized their high appreciation of the exotic's rare attributes in imperishable literature. Edmund Spenser, for example, was a great smoker, and as we have already seen, when he and Raleigh met in Ireland they would sit together by the hour over a soothing pipe, while holding delightful contests of reponsive versifying. In the Faevic Queene is a sweet passage telling how Belphœbe hastened into the woods to gather herbs to heal the wounded Timais :

For she of herbs had great intendiment,

Taught of the Nymph which from her infancy

Her nursed had in true nobility:

There, whether it divine Tobacco were,

Or Panachea, or Polygony,

She found and brought it to her patient dear,

Who all this while lay bleeding out his heart-blood near.

In a similar vein William Lyly, Queen Elizabeth's courtpoet, speaks of the weed in his play entitled The Woman in the Moone. Pandora, having wounded a lover with a spear, urges her attendant to gather

. . Balm and cooling violets,

And of our holy herb nicotian,

And bring withal pure honey from the hive,

To heal the wound of my unhappy hand.

Ben Jonson, Thomas Dekker, and a host of other play- 


\section{THE USE AND ABUSE OF TOBACCO 8I}

wrights and pamphleteers found in the new indulgence a source of endless amusement, and belaboured 'Tobacconists' with rare sallies of wit and humour.

Authors learned in the materia medica of those days tell of wonderful cures wrought by this Sana Sancta Indovum. In a bo ilet bearing the rather droll title of Dyet's Dry Dinner (1599) Henry Buttes informs the reader that 'Tobacco cureth any grief, dolour, imposture, or obstruction proceeding of cold or wind, especially in the head or breast. The fume taken in a pipe is good against rumes, hoarseness, ache in the head, stomach, lungs, breast, etc., also in want of meat, drink, sleep, or rest.' The dyspeptic and the sleepless are invited to banquet upon a dry dinner, and they will assuredly find in the pipe a neverfailing remedy for their several ailments. The uplifted author feels himself impelled to give expression to his high appreciation of the new regimen in verse, and exclaims,

Fruit, herbs, flesh, fish, whitemeats, spice, sauce, all, Concoct are by Tobacco's Cordiall!

Proceeding with his description of a dry dinner and elaborating many mysterious complications of the human system and their complete removal by the use of tobacco, he says that he 'names his book, Dyet's Dry Dinner, not only Caminum Prandium, without wine, but Accipritinum, without all drink, except tobacco, which also is but dry drink.' And as to the first introduction of tobacco into this kingdom, he informs us that it was 'translated out of the Indies in the seed or root, native or sative in our own fruit-fullest soil. The Indian name for the plant is Peicelt, surnamed tobacco, by the Spaniards of the Ile Tabago. Yet we are not beholden to their tradition. Our English Ulisses, renowned Syr Walter Rawleigh, a man admirably 
excellent in navigation and Nature's privy counsell, and infinitely read in the wide boke of the worlde, hath both farre fetcht it and deare bought it, the estimate of which I leave to other; yet this all know, since it came into request, there hath been Magnus Fumi Qestus; and Fumi-Vendulus is the best Epithite for an Apothecary.'

How enraptured medical men were with the new herb, believing that at last they had discovered the panacea of their happiest dreams, may be learned from Dr. Gardiner's Trial of Tobacco. On the title page of this rare quarto volume, published in London in 1610 , the author describes in prolix detail the contents of his book, thus:- 'Wherein his (tobacco's) worth is most worthily expressed : as in the name, nature, and qualitie of the same hearb-his speciall use in physick, with the right and true use of taking it, as well for the seasons and times, as also the complexions, dispositions, and constitutions of such bodies and persons as are fittest, and to whom it is most profitable to take it.' He asks: 'What is a more noble medicine, or readier at hand, than tobacco?' And he informs the reader that although he is an old man he undertakes the task of compiling the book in order to supply a proper knowledge of the plant so much in use among Englishmen. For the cure of the asthmatical, and such persons as are of a consumptive tendency, he prescribed liberally of Foliorum Sana Sancta Indorum combined with other medicaments unknown to modern therapeutics, and which may be readily accredited with very effectual properties-effectual, one would think, in dispelling the extravagant belief of the learned leeches of those days in tobacco as a 'soverane remedy.' How people managed to take such concoctions as Dr. Gardiner prescribed and live is beyond conception: their Spartanlike endurance shines out conspicuously under a treatment 


\section{THE USE AND ABUSE OF TOBACCO}

which embraces 'tobacco gruel,' 'tobacco wine,' also, tobacco made up into a kind of soup, or syrup, with sufficient sugar. The patient is recommended to drink the decoction hot, as a medicine good against the plague.

A glimpse of the strange notions which entered the heads of our forefathers respecting the medicinal virtues of the Indian weed may be gained from a perusal of the curious collection of odds and ends of social and literary gossip, contained in the Harleian Miscellany. Under the head of Tobacco the writer says he once knew some persons who every day ate several ounces of the herb without experiencing any sensible effect; and from this he infers that, 'Use and custom will tame and naturalize the most fierce and rugged poison, so that it will become civil and friendly to the body.' In the hands of the chemist it is perfectly true that some of the most virulent poisons can be made subservient to the healing art, and yield to the physician some of the most helpful medicines known to pharmacy; but it would be unwise to the last degree for the uninitiated in the mysteries of the laboratory to experiment upon himself in the vain belief that use and custom will carry him safely through the ordeal. The writer goes on to say that, "Some anatomists tell us most terrible stories of sooty brains and black lungs, which have been seen in the dissection of dead bodies, which when living had been accustomed to tobacco. 'I know a curious woman in the North, that does very great feats in healing the sick by a preparation of tobacco. And our learned and most experienced countryman, Mr. Boyle (experimental philosophy) does highly recommend tobacco for pains, which are often epidemical in cities and camps.' He appears, however, to have a wholesome dread of such experimenting, for he consoles himself now and then by remarking that 
'custom and conversation will make the fiercest creature familiar.' Yet he seems quite unable to break away from the common belief, that, 'the qualities, nature, and uses of tobacco may be very considerable in several cases and circumstances, although King James himself hath both writ and disputed very smartly against it.' The reader is next informed that a French author in the Journal of Science ( $168 \mathrm{r}$ ) has 'writ a peculiar tract on tobacco, wherein he commends it for bringing on sleep;' an idea probably derived from Dr. Thoriu's Hymmus Tabaci (1625) which passed through many editions in London, Paris, and Utrecht. In this elegant Latin poem Thorius playfully alludes to the drowsiness tobacco-smoking produced upon the gods :-

. . . The gods Bacchus, Liber,

Jove, Mars, Vulcan, Mercury, Apollo,

Lustily through their nose the smoke did take,

As if another Ætna they would make.

The goddesses, pleas'd with the novelty,

Laugh'd all the while, but when they did see

How much to sleep that night the gods were given,

Angry, decreed it should be banish'd Heav'n.

The purifying action of tobacco-smoke on unwholesome air was fully recognised in Pepy's time, when during the Great Plague of $1665^{-6}$ the pipe was to be seen in almost every mouth. Pepys like others sought protection in the weed, and purchased roll-tobacco to 'chaw.' Alas, poor man, it took away his apprehension! In his immortal diary is a note under date, June 7 th. 1665 :

This is the hottest day that I ever felt in my life. This day, much against my will, I did in Drury Lane, see two or three houses marked with a red cross upon the doors, and, 'Lord, have mercy upon us,' writ there, which was a sad 
sight to me, being the first of the kind that to my remembrance I ever saw. It put me in an ill-conception of myself and my smell, so that I was forced to buy some roll-tobacco to smell and chaw, which took away my apprehension.

Clearly Pepys was not a 'tobacconist,' but surely he should have known better than to have 'chawed' the black twist.

Dr. Willis, physician in ordinary to Charles the Second, speaks highly of the valuable antiseptic properties of tobacco. In his work entitled, $A$ Plain and Easy Method of Preserving (by God's Blessing) Those That are Well From the Infection of the Plague (1666) he remarks upon the exemption trom the pestilence of houses where tobacco was stored for manufacture or sale.

Nor indeed were those persons affected who smoked tobacco, especially if they smoked in the morning, a time when the body is more susceptible to outer influences than it is later in the day. For the smoke of the plant secures those parts which lie most open, namely, the mouth, nostrils, etc., and at once intercepts and keeps the contagion that floats in the air from the brain, lungs, and stomach. It also stirs the blood and spirits all over, and makes them throw off any contagion that may adhere to them.

In another treatise on the subject Dr. Willis makes equally shrewd remarks on the use of tobacco among soldiers and sailors. He says, "Tobacco taken in the vulgar way at the mouth through a pipe has effects not only manifold but diverse,' and he explains that its use, 'when it may be had, seems not only necessary but profitable for soldiers and mariners, for that it renders them both fearless of any danger, and patient of hunger, cold, and labour.' Army experiences of recent years bear testimony to the beneficial use of tobacco in almost the same words. 
The learned Dutch Physician, Dr. Diemerbroeck, of Utrecht, in his Tractatus de Peste (1635-6) lays stress on the good which he found to come of smoking tobacco. So fully was he persuaded of its powers to kill contagion that for his own sake he smoked almost continuously while attending upon his patients in the hospitals at Nimeguen during the prevalence of the great plague in Holland. He began the day with a pipe; after dinner he would take two or three more, and a like number after supper; and if at any time he felt himself affected by his surroundings he immediately had recourse to the weed, which he regarded as his comforter in affliction and preserver from the plague. Dr. Diemerbroeck would seem to have been a model officer of health. Armed with his chosen instrument he gallantly charged the enemy at all hours and in all places, striding along the aisles of death unscathed. His services were invaluable, and ought surely to have been utilised over a larger area than they were. As Smoking Sanitary Commissioner he might have visited, say, Cologne, where much to the advantage of the inhabitants, more particularly to visitors, he doubtless would have founded a TabakoCollegium. Coleridge would then most likely have been spared his discomfiture and precipitate rout on his encountering there 'seventy-two separate and well-defined stinks.' The Farina Brothers doubtless loved their quaint city whose quainter smells have passed into a proverb, and were animated with sublime ideas of patriotism when they concocted their sweet-smelling waters which were to bring back to it wealth and renown. Their success has equalled their genius : all the world is grateful for Eau de Cologne.

We now approach the threshold of new and more enlightened views of the uses of tobacro. From the first 
inception of the idea of its possessing curative properties it passed through two distinct phases in the medical world. First it was received as a heaven-sent boon to suffering humanity, and was applied with a lavish hand for the cure of every malady. Then followed bitter experiences of pain and even death inflicted in cases where it had been fondly hoped relief would be obtained. We see medical practice struggling in a dim uncertain light towards fuller knowledge, yet baffled at every step. Reluctantly the doctor is driven to forsake his new love, and again we see him turning to the plants of his native soil for the realisation of the great dream of his life, - a panacea, which to him meant all that the philosopher's stone could signify to the alchemist; and once more we hear of Solar Elixirs, and of occult medicaments prepared from herbs gathered in the glimpses of the moon; for it was argued that the ruling heavenly bodies from whose energy divine had sprung all life, must assuredly have provided remedies for the evils with which life is burdened. The reaction which followed upon the disappointment was so strong that tobacco became the shibboleth of the profession, whose leading spirits denounced as charlatans all who ventured to remain faithful to the creed of the tobacconist. This second stage reached its culmination half a century ago, when Mr. Lizars, and Mr. Solly, of St Thomas's Hospital, inaugurated a crusade against tobacco, holding forth on the physical and mental misery, leading to insanity, which must inevitably follow its use in any form. One instance among many may suffice to indicate Mr. Solly's method of terrifying smokers. He speaks of a young clergyman of his acquaintance who could only write his sermons under the stimulus of a pipe ; he admits that his discourses were eloquent, even brilliant, and profitable to listen to. Then Mr. Solly, pointing an 
admonitory finger, utters the solemn warning-'but the end of that man is not yet!'

Fortunately there is no longer need to consider whether the weed deserves the hard things said of it, or whether it is to be ranked among the chief blessings a beneficent Providence has conferred upon this nether world. These things are settling themselves in their proper places under the critical eyes of modern science, and the larger and more rational views derived from experiences in the field, the camp, and the hospital. Conspicuous among medical treatises of recent years, wherein the subject is dispassionately surveyed, may be mentioned that of Dr. John C. Murray, of Newcastle-on-Tyne. Remarking upon the observed curative effect of tobacco-smoking on the sick and wounded in the Franco-German war, he says that its healing virtues were so obvious to an army surgeon of his acquaintance that from being strongly opposed to the use of tobacco he became a convert, in so far that he actually purchased cigars and presented them to the wounded, in consequence of having observed that their smoking assisted recovery. ' This experience,' adds Dr. Murray, 'is contrary to what has been enunciated as theory, or deduced from isolated examples taken from the hospitals. Practical observation from previously healthy men must, however, be allowed precedence of speculation when inferred from disease.' This admission marks a decided advance towards harmonising the faults of speculative reasoning with the actual experience of every-day life.

Taking a general survey of army medical officers' reports of work done in the hospital-camps, he finds evidence in abundance supporting the view that tobacco-smoking does in some indefinable way mitigate suffering and help to a speedy recovery. Not only were the good effects manifest 
in the comfort it afforded the men on the march, but chiefly in the camp and the hospital, where under its soothing influence the wounded were often snatched from death and the sick restored to health. An amusing incident of a wounded soldier's love for his pipe is noted in a lady's diary kept while occupied as a nurse in a British hospital. Private McCarthy while under chloroform had just had one of his toes amputated by the surgeon. The wound bled freely, and the surgeon, after binding it up, left strict injunctions that the man was not to put his foot down. It happened that the nurse was called away to another patient for a few minutes, but before leaving she reminded the patient of the doctor's orders about remaining still. On her return, to her astonishment the man was nowhere to be seen. After some searching she discovered him by traces of blood on the floor, quietly seated in the yard smoking his pipe. To her admonition about disobeying orders, and concern for the injury he was likely to do himself, he paid no heed, and continued smoking in happy indifference. Better success attended her endeavour to bring him to a repentant frame of mind when she told him of how he had disfigured the floor with his blood. Then he rose and quietly returned to his bed, saying, 'Indeed, ma'am, I could not help going to have a pipe, for sure, that was the nastiest stuff I ever got drunk on,'-alluding to the taste of the chloroform.

Besides being a social comfort to the soldier on the march and in camp, the wholesomeness of the weed has long been recognised in the Army. Lord Wolseley on the occasion of his rapid dash to Coomassie gave proof of his belief in its prophylactic properties when on landing at Cape Coast Castle he caused pipes and tobacco to be dealt out to the men. George Gilham, of the and Battalion, 
Rifle Brigade, writing from the ranks tells of his experiences on the march, and says, "The climate about Cape Coast Castle is bad, and the stenches we came upon almost knocked us over. But the General had pipes and tobacco served out to us with orders to smoke for protection. I was then no smoker, but I soon managed to learn the art.' And Corporal J. C. Ives, of the Buffs, bears pathetic testimony to the soldiers' love of a pipe of tobacco during some hard service, fighting the Zulus. After describing a fierce encounter with the enemy he concludes with this lament: 'The worst of all was we had no tobacco, the last having been already issued. We did not know we had so little in our possession when we sold some to the Kaffirs in charge of the track oxen. When we found all was gone we would have given double the value of it, but it was too late, and we were induced to try experiments with dry tea-leaves, grass, and coffee grounds. Some of the men found a herb which they smoked, but this had the effect of making their heads swell to such an extent that they had to be attended by the doctor.' On another occasion when the 9ist Highlanders came within sight, and greeting cheers had resounded on the still night air, he says, "When our friends arrived the first question from the Ekowe garrison was, "Have you any tobacco?" Oh, that smoke! The same night we were served out with a tot of rum, white biscuits and a smail piece of tobacco, luxuries subscribed for by the inhabitants of Port Natal.'

With innumerable experiences such as these before them it is difficult to understand the action of the Home authorities in dealing with contraband tobacco seized by Custom-house officers. Some years ago a ton of tobacco and cigars was seized at Portsmouth, the whole of which was buried in order to get rid of it. A protest was made, and 
the reasonableness of distributing, instead of wasting, such seizures of tobacco among the men of the Army and Navy could not be gainsaid; and it was satisfactory to learn that the Revenue Department had been moved to issue directions to the proper officers to, in future, supply troop-ships with seized tobacco at the rate of one ounce per diem for each man. But this humane practice was soon discontinued; indeed, the arrangements for the disposal of seized tobacco present some curious features, and have varied considerably from time to time. The course pursued with such seizures, including that unreleased by consignees from the bonded warehouses at the London Docks, had been the very primitive one of burning it in an instrument known and recognised as the 'Queen's tobacco-pipe.' Possibly some outdoor officer of Customs hit upon the device in order to shield himself from blame for thus wasting good stuff. It was a huge instrument of enormous ventrical capacity and would fume away hundreds of tons in a few.hours. Then an afterthought of economy crept in, and suggested that the ashes might make good manure. They were accordingly sold to agriculturists for what they would fetch; a ton of the ashes it was found served as tillage for four acres of ground. But this monster pipe is now put out; it was arranged that future seizures of contraband tobacco, and also such as remained in Bond unclaimed on account of its having sustained damage in transit from the place of exportation, should be thrown upon the market for sale, a course which did not commend itself to the trade, nor to the palate of dainty smokers. In face of the difficulty another arrangement was made for its disposal; the criminal lunatics confined in certain Government asylums were thought of, and gratuitously provided with tobacco from this source. Large quantities were 
also supplied to certain public botanical gardens where tobacco is required for the destruction of insect life, and which would otherwise have to be purchased at the public expense. If after meeting these demands a sufficient quantity of tobacco was available, then troops ordered on foreign service were furnished with a supply for use on the voyage. Strange to say, even this small chance of obtaining a little comfort for the men who are to fight our battles in fureign lands under hardships which tax the strongest powers of endurance has ceased. Troop-ships at the best of times are none too comfortable, and anything that can be done towards making those on board contented would be a distinct gain to the Service. Both policy and humanity indicate a little generous treatment of the men upon whose prowess the existence of the Empire so largely depends. It is hard to believe that criminal lunatics can have a better claim to the indulgence than our soldiers.

Referring to the antiseptic properties of tobacco, Dr. Murray says that he is fully convinced from close observation, that though it does not produce ozone it is an excellent disinfectant; and he mentions instances of ladies who, while attending upon their relatives laid up with a fearful epidemic inalady, recognised, as if by intuition, the advantage of smoking. On one occasion a lady came into the sick-room where he was seeing a confluent case of epidemic small-pox puffing a cigar, and upon his remarking it she pointed to the patient with a triumphant air more eloquent than words. Whereupon Dr. Murray with a touch of oldfashioned chivalry says, 'I immediately bent to her as a Master.' In the same gay vein he continues: 'I have myself seen, and also been informed, that many ladies during the current epidemic have given pronounced evidence of their faith in the antiseptic virtues of tobacco by 
selecting the smoking compartments when travelling by rail, and not a few have even in severe cases while waiting upon their relatives trusted to tobacco as a safeguard. I am happy to add that so far they have rejoiced in an immunity from the most contagious disease with which the present age is acquainted.'

Drs. Klein, Tassinari, Werke and other distinguished bacteriologists have carried their investigations into this interesting field of research with marked success.

Dr. Klein, of St. Bartholomew's Hospital, says that 'direct experiment proves that tobacco-smoke has a decided germicidal effect; it is not known, however, which is the active principle in the tobacco-smoke.' He also remarks that the popular idea which has again sprung up of tobacco's prophylactic powers, 'is well supported by laboratory experiment.' Dr. Tassinari, adopting the microscopical methods of Pasteur, illustrates his investigations into the subject and the results obtained by a series of charts. These results may be briefly summarised. He found that the smoke of tobacco in some cases entirely destroyed, in others retarded the development of, microorganisms. For example, the bacilli of Asiatic cholera and pneumonia were in every instance destroyed by the smoke of tobacco irrespective of the kind or quality of the tobacco used. Anthrax bacilli and the bacilli of typhoid offered greater resistance, the latter indeed were but little affected by the smoke. He makes an odd remark about the surprising growths of germs found by the microscope adhering to the coating of the teeth, and says that as tobacco-smoke destroys them, it is a preventive of decay; should it darken the enamel, the ashes of the weed used as a dentifrice will make them whiter than before.

Similar investigations have been made in Spain and 
Germany. Werke saturated a cigar with a liquid fully impregnated with cholera bacilli and found that in twentyfour hours every germ was destroyed. He next placed bacilli upon dry tobacco leaves; in this case they were rendered harmless in half an hour. In other trials a contact with the leaf of three hours was required for their destruction. Strange to say, damp tobacco was the least effective; the germs struggled hard for existence, and held out for three days before yielding up their lives to the superior genius of the weed. A fifty per cent. solution of tobacco over-mastered them in twenty-four hours. But it is in burning tobacco, when its elements are liberated from their confinement, that the battle is most decisive. Werke says, that when he tested them with the smoke of tobacco every germ was rendered incapable of propagating disease in less than five minutes.

Though the medical man whom duty calls to denselycrowded, unwholesome districts fortifies himself against attack from the invisible foe with a Manila or Cuban leaf, he protests emphatically against the smoking habit which has recently cropped up among boys. The boy-smoker, besides being a nuisance, is rendering himself physically and mentally unfit for the duties of life. 


\section{CHAPTER VI}

\section{ON THE ANTIQUITY OF TOBACCO-SMOKING}

Like Horace's greybeard, we are all more or less prone to look lovingly towards the past, to regard the days of our forefathers as the good old times in which they played their part in life's drama on a larger and nobler scale than we do, or are capable of doing. In this spirit of admiration for antiquity we see the beginnings of that hero-worship which with the Greeks gradually developed into their beautiful mythology. They, above all other people, delighted to extol the powers and achievements of their ancestors; they clothed them with the attributes of deity, and strove to emulate and honour them in all manly deeds; thus they exalted their own conceptions of life, and idealised the course of their national existence. And yet this innate tendency to magnify and extend into the dim, illimitable regions of antiquity whatever of human effort is deemed most worthy, is it source of difficulty to the conscientious student. Amid the wild growth of myth and marvel the antiquary or archæologist warily treads his way to surer ground, and out of scattered fragments of a by-gone age constructs anew an old order of existence, or opens a vista to the mind's eye through which glimpses may be gained of the habits and inner life of our remote ancestors. Then it is we see the present linked with the past in one unbroken 
chain; our knowledge is enlarged, and we recognise the unity of our race. Needless then to say that it is in no narrow spirit of mere curiosity that the wise men of Europe have devoted much labour and learning to the task of discovering if the habit of tobacco-smoking, now so common all over the world, existed in Eastern countries before the discovery of America by Columbus.

It is justly claimed for the subject that it possesses interest for a much larger class than professed ethnologists; that it is invested with an absorbing fascination for every earnest student of the history and habits of mankind. For it is maintained that nothing but a deep-seated craving in the nature of human beings for narcotics and stimulants can explain the immediate, rapid, and over-mastering success with which the passion for tobacco spread over the world after its introduction into Europe by the Spaniards. That this should have been so, seems to point directly to the conclusion that before the discovery of the New World the tobacco-plant and the habit of smoking its leaves were unknown elsewhere. Let it be remembered, however, that we have to take into account the farther East, more particularly China, the Cathay of our forefathers, who had found every approach leading into the interior jealously guarded against intrusion from the barbarian of the outer world.

Scattered through the pages of ancient historians and naturalists are some curious allusions to a practice occasionally indulged in of inhaling the fumes of burning vegetable substances, either for pleasure's sake or for medicinal purposes. A few of these may suffice to indicate the shifts men were put to in remote times in order to appease their longing for narcotics of one kind or another. 
Herodotus says that the Messagetæ, or Scythians, possessed a tree bearing a strange fruit which, when they met together, they cast into the fire and inhaled its fumes till they became intoxicated, in much the same way as the Greeks did with wine. What this strange produce was we learn in book IV., cap. 78, where he relates the story of the Scythians making themselves drunk with hemp-seed. They crept with it under their blankets, and, throwing it on red-hot stones, inhaled the fumes arising therefrom. Simple narrations such as these fall in quite naturally with one's ideas of primitive man adapting himself to his circumstances. The Father of History never indulges in flights of fancy or creations of the imagination; it is enough for him to render a straightforward account of such things as came under his own eyes, or of events as they had been related to him. But when we come to a modern writer who tells a smoking-story of far-back times, relating, indeed, to none other than the 'mighty hunter before the Lord,' (enjoying, we may assume, a quiet pipe after a day's hard riding across country), then doubt begins to take possession of the mind, and we are inclined to let that tale go for what it is worth. Lieutenant Walpole is responsible for the story that, when he was at Mosul, there came into his hands a very old Arabic manuscript, in the opening chapter of which the ancient scribe declared that Nimrod used tobacco. Application of the higher criticism to this relic of antiquity would be quite out of place; why, indeed, should men seek to be wise above what is written? But let us look a little farther into what Mr. Walpole has to narrate of the people among whom he sojourned, respecting their indulgence in the social pleasure of the pipe. From his highly interesting work on The Ansayrii, or The Assassins (published in $185 \mathrm{I}$ ) we gather that while at Mosul he was 
so impressed by the prevalence of the habit of smoking among all classes, that he made diligent inquiry of the learned of the land respecting its origin; for he felt convinced that nothing European, much less American, could possibly have crept into this remote district of the Old World, whose inhabitants were living as their fathers had lived for ages. 'In the East,' he writes, 'it is rare to find a man or a woman who does not smoke. Enter a house, and a smoking-instrument is put into your hand as naturally as you are asked to sit down.' Mr. Walpole had not long to wait before his new friends found means of satisfying his curiosity and of quickening the interest already awakened within him as to the antiquity of the habit. A venerable sage disclosed to his wondering eyes the manuscript aforesaid. It filled over a hundred closelywritten pages, and was divided into eight chapters, in the first of which was related the story of Nimrod. The origin of the different opinions for and against tobacco are enlarged upon in its pages; this, by the way, seems to imply that the Koran had not settled the disputed point; but then these Hashishins, who had found tobacco a far more grateful comforter than their fiery hashish, were not good Moslems. Unfortunately for Mr. Walpole, the happy owner of the priceless document, this inestimable relic of antiquity, was a bibliomanist whom nothing could induce to part with it; but he tells the reader that it was being copied-a lengthy process. Youthful exuberance of spirit marks Mr. Walpole's joy at the discovery. 'Lovers of the weed,' he exclaims, 'may reasonably hope that the elucidation of the Assyrian history will show us Nimrod making kief over the chibouk, and Semiramis calling for her nargilleh. It would enhance the grace of Cleopatra could we imagine her reclining on a divan of eiderdown 
toying with Marc Antony as she plays with her jewelled narpeesh.' His enthusiasm is kindled by glowing tales of Eastern life, stretching back to the remotest ages; he sees the folly of entertaining for a moment the thought that Asia could be indebted to America for the luxury of the pipe. 'We can hardly suppose,' he writes, 'that in the comparatively short space of time since the continent of America was discovered by us, the habit could have spread through Europe to the very utmost corners of Asia; that the Burman would smoke his cigar as he does, and the wild man of the forest of Ceylon would make his hand into a bowl and smoke out of it. These people, perfect wild beasts, double up the hand, curving the palm, and thus form a species of pipe; a green leaf protects the hand; within this the weed is placed, and thus they smoke. This is certainly the youth of smoking. Adam may have practised this method, even in the days of his innocence.'

It is, perhaps, a pity Mr. Walpole did not feel satisfied with this display of youthful gaiety. Possibly he saw that something was still wanting; that his new-born idea of an Eastern origin for the weed he loved was too weak to stand without support. At that very moment some evil genius whispered in his ear the fun of sending the reader a wool-gathering to the British Museum. Then it dawned upon him that among the marvels of antiquity the excavations of Botta and Layard were laying bare to an astonished world was an Assyrian relic which would bear oracular testimony to the truth of the old Arabic manuscript found at Mosul, and that henceforth Nimrod must be regarded as the paladin of the pipe. So Mr. Walpole goes on to say; 'If the curious reader will go to the British Museum he will there see an Assyrian cylinder, found at Mosul, and presented to the Institution by Mr. Badger, 
whereon is represented a king smoking from a round vessel, attached to which is a long reed.' Hours have been spent in vain at the British Museum in making careful search for this interesting object. Doctor Wallis Budge, who presides over the Egyptian and Assyrian antiquities, knows nothing of a cylinder bearing an inscription of a king smoking a pipe. He has, however, a record to the effect that Mr. Badger, on February 8th, I845, gave the Museum 'the squeeze of an inscription, the impression of a seal, and a bronze object.' Doctor Budge warily remarked: 'I must remind you that in 1845 all sorts of nonsense was talked about Assyrian objects; but that two men [a second writer had been mentioned who had evidently copied, on faith, from Mr. Walpole] should state such a thing without verification is remarkable. I am sorry for your wasted time-and my own!' Assyrian cylinders in the British Museum are numerous, and interest in them is heightened by written explanations in our own tongue placed by the side of each of the markings upon them, giving also the date or period to which the object belongs. The student is thus enabled to grasp with his senses lessons in history which, without this aid, would be vague and unreal. Yet, so grotesque are some of the figures, that little need for wonder if the eye of faith should discover what it seeks for.

The ascetic of the Greek Church, however, can eclipse this story of Nimrod and the Assyrian monarch who loved his pipe, with a tradition carefully preserved in its archives of Noah himself, tempted by the Evil One, having fallen under the intoxicating fumes of tobacco. The ingenuous scribe relates (though this may be apocryphal) that Noah, resting upon the summit of Mount Ararat after his toils on the swollen waters, happened to place his hand on a 
tobacco-pipe charged with the comforting herb, and Satan, envious of his happiness, urged the patriarch to prolong the indulgence until sleep fell upon his eyes. Where the soil is ready for the seed the merest figment takes root and flourishes abundantly.

Persons of a poetic temperament who find in speculative dreaming pleasure more satisfying than aught they can derive from the study of prosaic reality, usually turn their thoughts towards the East, to the land of mystery and gorgeous imagery, where man first awoke to a wondering contemplation of the phenomena of nature, asking himself what the earth and sky could be, and marking out in bold outline as he gazed into the star-lit firmament the signs by which we to-day recognise the zodiac. Entering these regions of hoary tradition, the marvel-loving wanderer from the West finds his path strewn with relics of our early progenitors; here he may revel in endless variety of legendary lore garnered from rich fields of poetic fancy. Does he wish to learn of the Moslem sage the origin of the weed whose balmy breath

\section{From East to West}

Cheers the tar's labour, or the Turkman's rest?

Let him listen to his words as he relates how the Prophet, walking in his garden at early dawn, came upon a viper stiff with cold, lying in the grass. 'Full of compassion, he took it up and warmed it in his bosom; but when the reptile recovered, it bit him. "Why art thou thus ungrateful?" asked the Prophet. The viper answered: "Were I to spare thee, another of thy race would kill me, for there is no gratitude on earth. By Allah, I will bite thee." "Since thou hast sworn by Allah, keep thy vow," said the Prophet, and held out his hand to be bitten. But as the reptile bit 
him, the Prophet sucked the poison from the wound, and spat it on the ground. And lo! there sprang up a plant in which the serpent's venom is combined with the Prophet's mercy, and men call it tobacco.'

Unhappily for the champions of Asia's prior claim to the weed, those enchanted mirrors of Arabian social life, The Thousand And One Nights, reflect no sign, not the faintest shadow of aught resembling circling eddies from the tobacco-bowl. In the early days of the new indulgence its lawfulness was warmly disputed in Mahomedan countries. Both Sultan and Shah looked with suspicion at this new device of the Giaour, and inflicted the severest punishment upon all who ventured to console their sorrows with the pipe. In the warmth of conflicting opinion, the Koran was appealed to, and a Moslem ascetic was found who read to the faithful a passage (from a revised version, no doubt) wherein it was foretold that, 'In the latter days there shall be men bearing the name of Moslem, but who are not really such, and they shall smoke a certain weed which shall be called tobacco.' A device so simple, giving the American name of the plant, could deceive no one but those who were willing to be deceived. It helped, however, to smooth the way towards the desired reconciliation; and then the Turkish traveller, Eulia Effendi, contributed towards a peaceful solution of the much-vexed question the best fruits of what little ingenuity he possessed. He declared that he had found, deeply embedded in the wall of an old edifice, so old that it must have been reared long before the birth of the Prophet, a tobacco-pipe which even then smelt of tobacco! The pious frauds of Moslem ascetics could not go beyond this. Here was the sanction of antiquity, if not of the Prophet, for the indulgence they all loved, before which Sultan, and Shah, and Koran gradually gave way, 
yielding to St Nicotine the mild sway she holds over her votaries. And it must needs be admitted that the claim for a knowledge of tobacco in Western Asia before the days of Columbus has no stronger prop to rest upon than this pipe found in the crevice of an old wall, and which still smelt of tobacco,-dropped in by some poor Turk fearful of the torture in store for him if caught smoking. Russell, in his narrative of a visit to Aleppo in $x 603$, says that tobaccosmoking, then so commonly indulged in at hoine, was unknown there. And Sandys, writing of the Turks as he found them in 1610 , speaks of tobacco as just introduced into Constantinople by the English. How rapidly the taste for the weed spread over the countries of the near East, and the hold it had taken upon all classes, is shown in many a homely saying among the people, such as, 'A pipe of tobacco and a dish of coffee are a complete entertainment;' or, in the Persian proverb that, 'Coffee without tobacco is meat without salt.'

Doctor Yates had gone to the land of the Pharaohs for enlightenment on things hidden from the vulgar; and among other things rare and wonderful which presented themselves to his astonished gaze, he gravely assures the reader of his Modern History and Condition of Egypt (published in 1843) that on the wall of an ancient tomb at Thebes he saw a painting in which was represented a smoking-party; beings of our own species sitting together enjoying, possibly, social chat over the fragrant weed. Here was indeed one of those touches of nature which makes the whole world kin. Standing in the mystic glow of an Egyptian sky, in the living presence of the marvellous works of men's hands wrought six thousand years ago, his imagination bridges the space of ages, and he realises the unity of our race in the familiar scene before him. The 
uplifted doctor did not recognise in the painting a representation of the ancient art of glass-blowing. The tricks the imagination plays upon us at times would be very amusing were it not for the ruffle they give to one's selflove. Some men, rather than admit they were, or could be deceived, will hold to their error through all time and in the face of every rebuff.

It is not improbable that some varieties of the tobaccoplant may be indigenous to the Old World. There are about forty, of which seldom more than three are cultivated for consumption as tobacco; Virginia (Nicotina tabacum, Syrian (Nicotina rustica), and Shiraz (Nicotina Persica). Diligent research, however, extending over many years, has failed to bring to light any evidence of the existence in Europe or western Asia of either of these plants before the Spaniards discovered America. The allusions made by Dioscorides, Strabo, and Pliny to a practice common among both the Greeks and the Romans of inhaling the fumes of tussilago and other vegetable substances, have no bearing on tobacco-smoking, nor on any general habit. They refer rather to the use of certain herbs as remedies for affections of the throat and chest, used much in the same way as our forbears used certain other herbs for the cure of similar ailments. Most people condemned to suffer the rigours of an English winter have experienced kitchentreatment of the kind, when shrouded in a blanket over a bowl of steaming medicaments they lay siege to the citadel held by the bacteria of influenza. From Pliny we learn that a tribe of unknown barbarians burned the roots of a species of cypress, and inhaled the fumes for the reduction of enlarged spleen-a malady very common among the inhabitants of the plains of southern India. He tells us also (xxiv., 84) that the Romans smoked coltsfoot through 
a reed or pipe for the relief of obstinate cough and difficult breathing. Here it may be of interest to mention the discovery in recent years of a small description of smoking-pipe, resembling in size and form the cutty of the Scot or the dhudeen of the Irish peasant, among Roman structures, both in these islands and on the Continent.

Dr. Bruce, in his History of the Roman Wall, speaking of these pipes, asks: 'Shall we enumerate smoking-pipes amongst the articles belonging to the Roman period? Some of them have, indeed, a medieval aspect; but the fact of their being frequently found in Roman stations along with pottery and other remains, undoubtedly Roman, should not be overlooked.' The Abbé Cocket had found similar clay pipes in the Roman Necropolis near Dieppe, and in his work on subterranean Normandy he says they must surely have belonged to the seventeenth century. But, on subsequently hearing of Doctor Bruce's discovery of similar pipes in his exploration of the Roman Wall, he reverted to his first opinion, that those he had himself found were indeed Roman. Since then Baron de Bonstetten has investigated the subject; and in his work entitled Recueil des Antiquites he gives drawings of these pipes, and declares his opinion to be that they are fair specimens of European smoking-instruments in use before the days of Columbus, and possibly before those of Julius Cæsar. That smoking-pipes have been found among authentic Roman remains is beyond question. What use the Romans made of them we have already learned from Pliny; and doubtless the Roman soldier, on outpost duty in this fog-begirt island, would often have need of whatever little comfort he could get out of his small pipeful of coltsfoot.

Both in Ireland and Scotland somewhat similar pipes 
have been picked up in remote places, and have been attributed by imaginative country folk to the fairies and elves, to the Celts and to the Danes. Raleigh's sowing the seeds of Ireland's first tobacco-plant in his garden at Youghal is lost sight of in a desire to yield to antiquity the credit due to modern enterprise. About a century ago (to be exact, in the year 1784 ), the fine Milesian imagination was afforded an opportunity of soaring into the glorious region of an indefinable past, when the headman of every village was indeed a king. In an ancient tomb-far too old to bear the vulgar indication of a date-which had been opened at Bannockstown in Kildare, there was found firmly held between the teeth of the silent occupant a tobacco-pipe, small, but perfectly formed. Here, then, was positive proof of the antiquity of smoking in Ireland, ages, possibly, before the Saxon or Danish barbarian had invaded her shores. This important discovery naturally created a commotion among the learned of the Emerald Isle, which soon found mellifluent expression in the Journal of Anthologia Hibernica. Visions of a revivified Celtic history, clothed in the poetic vestments which properly belong to a venerable, half-forgotten past, rose to cheer young Ireland's aspirations; and now could be sung with renewed fervour,-

Let fate do her worst, there are relics of joy,

Bright beams of the past, which she cannot destroy.

It is not pleasant to be robbed of a cherished belief. The awakening breaks upon the shores of romance as would a London fog on a Swiss lake; yet it must needs be said that under the critical eye of the expert the vision dissolved, and left but an Elizabethan pipe behind. For such, indeed, was the fate that befell the famous Celtic 
tumulus and pipe of Bannockstown in Kildare. Stories, fanciful and fairy-like, relating to small pipes found in Irish by-paths, are mentioned in Mr. Crofton Crocker's Fairy Legends of Ireland. The peasant who picked up one of these always knew that it belonged to the Cluricaunes, 'a set of disavin' little devils,' he would explain, 'who were always playing their thricks on good Christians;' and with a few words of choice brogue he would break it and throw the bits away. Ireland, however, does not stand alone in that legendary lore wherein pipes have played their little part in life's romance. In Worcestershire there still lingers, or did linger until the scream of the locomotive startled the woods out of their sylvan dream, a fairy tale of Queen Mab having held her court at a spot near old Swinford, where a number of smoking-pipes had been found, so small that none other than fairy fingers could have made them for fairy mouths. So there grew up among the country folk gifted with a light fancy, the belief that Queen Mab had presided at her revels in the dell, distributing among her troop the fairy pipes they had found, while sighing on the breeze,

Come away elves, while the dew is sweet, Come to the dingles where the fairies meet.

Leaving the aerial domain of fairy-land, our thoughts are wafted to Central Asia, still in search of an Eastern birthplace for the weed. In the writings of a Hindoo physician, examined by Doctor Mayer of Konisberg in the course of his Eastern researches, it is stated that tobacco was first brought into India by the Franks in the year 1609 , that is to say, nearly a century after its introduction into Europe. The date agrees well with the progress the Portuguese had at that time made in establishing themselves in India, 
For nearly a century they had been in possession of Goa ; they held important seats of commerce in various other parts of India, and had command of the greater part of the oriental trade. These earliest of European explorers in the far East, having about the close of the fifteenth century made a successful passage round the Cape of Good Hope, were not slow to secure for themselves a footing on the western shores of Asia, and onward to the Indian Archipelago. Wherever they settled they introduced the American habit of smoking, and eagerly was it adopted by the different peoples with whom they had dealings. In the annals of Java, tobacco is stated to have been imported into that island, and the habit of smoking it taught to the natives by the Portuguese in r6or. To the Portuguese and the Spaniards, fortified later by the prodigious puffing powers of the Dutch, may be fairly ascribed whatever credit may be due for spreading a knowledge in the Eastern World of the habit which, for weal or for woe, has exercised a more potent witchery over man's life than probably any other indulgence, largely modifying and usually soothing and sobering his temperament. It seems but reasonable to suppose that if the plant and its use as a narcotic had been known in the East generally, independently of Europe, the indefatigable Jesuits, who penetrated into almost every nook of the Old World likely to afford a see to Rome, would have made the discovery and noted the fact with their usual accuracy. The illustrious traveller and naturalist, Palias, however, takes a different view of the question. 'Amongst the Chinese,' he writes, 'and amongst the Mongolian tribes who had the most intercourse with them, the custom of smoking is so general, so frequent, and has become so necessary a luxury, the form of the pipes, from which the Dutch seem 
to have taken theirs, so original; and lastly, the preparation of the dried leaves, which are merely rubbed to pieces and then put into the pipe, so peculiar that they could not possibly have derived all this from America by way of Europe, especially as India, where the practice of smoking is not so general, intervenes between Persia and China.' But surely this reasoning is merely an example of drawing inference from insufficient data; from what at best bears the appearance only of probability.

The learned botanist, Meyen, speaking of China in relation to the habit of smoking, deals with another and more pertinent aspect of the question. 'It has long been the opinion,' he remarks, 'that the use of tobacco, as well as its culture, was peculiar to the people of America; but this is now proved to be incorrect by our present more exact acquaintance with China and India. The consumption of tobacco in the Chinese Empire is of immense extent, and the practice seems to be of great antiquity, for on very old sculptures I have observed the very same tobacco-pipes which are still used. Besides, we know the plant which furnishes the Chinese tobacco; it is even said to grow wild in the East Indies. It is certain that this tobacco plant of eastern Asia is quite different from the American species.' The tobacco grown in China is very light in colour and almost tasteless, possessing a very small amount of the essential oil, one or two per cent. as against seven or eight per cent. yielded by the Virginian plant. Experiment, however, has brought to light the fact that climate and soil are really answerable for all the difference between the two kinds; that the Nicotiana tabacum of America for example, when transplanted into Syrian soil, has after a few years' cultivation lost its marked characteristics and become a light-coloured, mild tobacco, 
like the Shiraz herb. Meyen's argument would have had more value if he had been able to assign a date to the sculpture on which he had observed representations of tobacco-pipes, or if he himself had seen and examined specimens of the tobacco-plant said to grow wild in the East Indies. As his statement lacks the certainty which authenticated facts alone can give, it leaves the question still unanswered. The two Lazarists, MM. Gabet and Huc, whose zeal and heroic enterprise carried them safely through the wildest districts of Tartary and Thibet, make no mention of the practice of smoking among the inhabitants of those countries; though in China they had noticed outside tobacconists' shops an effigy of the tobacco plant, which they took to be a representation of the royal insignia of France, for they speak of it as the fleur-de-lis. Doubtless China rose in their estimation when they beheld so flattering an acknowledgment of its indebtedness to the grand nation for the blessing the herb conferred on an unworthy people. But if such were their impression they greatly erred. The inhabitants of the Celestial Empire (Tin-shan) entertained notions of a very different character. Their country (Chung-tow) occupied the centre of the earth, and all beings outside their borders they regarded as Fan-qui, barbarian wanderers, or outlandish demons. The exalted ideas they had formed of themselves led them into the happy delusion that they were the lower empire of the celestial universe. 'In the heavens,' says M. Pingré, 'they beheld a vast republic, an immense empire, composed of kingdoms and provinces; these provinces were the constellations : there was supremely decided all that should happen, whether favourable or unfavourable, to the great terrestrial empire, the empire of China.' Their historians carry back the traditions of their country to a period so 
remote (millions of years) that Europe can only be conceived of as primeval forest, and its inhabitants as barely emerging from their protoplasmic swamps. It is, moreover, a country of fantastic oddities, of topsy-turvy notions of the proprieties of every-day life; where you are constantly meeting with gentlemen in petticoats and ladies in trousers, the ladies smoking and the gentlemen fanning themselves: where ladies of quality may be seen toddling like animated walking-sticks, while stout fellows sit indoors trimming dainty head-dresses for them. Go outside the city and you find greybeards playing shuttlecock with their' feet or flying curious kites, and others chirruping and chuckling to their pet birds which they have brought out to take the air, while groups of youths gravely look on regarding these juvenile pastimes of their elders with becoming approval.

Early in the course of European adventure in the far East, travellers who, under various disguises had succeeded in penetrating into the interior of China, found in some provinces the cultivation of tobacco ranking among the foremost of their agricultural productions. Bell, in his Travels in Asia (Pinkerton's Edition, 181 I), speaking of China, says: 'I also saw great plantations of tobacco which they call "Tharr," and which yield considerable profits. It is universally used in smoking in China by persons of all ranks and both sexes; and besides, great quantities are sent to the Mongols, who prefer the Chinese method of preparing it before any other. They make it into gross powder like sawdust, which they keep in a small bag, and fill their little brass pipes out of it without touching it with their fingers. The smoke is very mild, and has a different smell from ours. It is reported that the Chinese have had the use of it for many ages.' Tobacco and the habit of smoking it are mentioned in the annals of the Yuen 
dynasty, about two centuries before Columbus had discovered America. Those who cry down every other than an American origin for the weed, assert that the Chinese

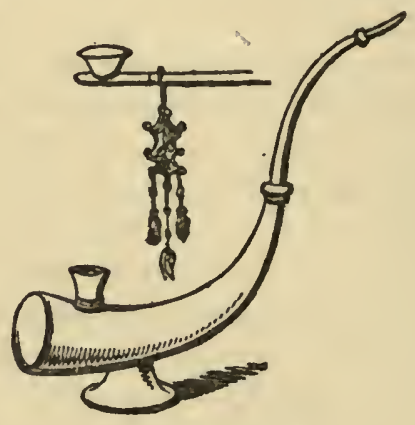

A CHINESE PIPE.

product is not tobacco, but some other herb used in the same way. Botanists, however, have shown this opinion to be erroneous. The great plain of Ching-too Foo is noted as the region where the culture and manufacture of tobacco are conducted on a more extensive scale than in any other part of the empire. In this plain the district of Sze-Chuen stands out prominently as the great centre and mart of the industry; from its plantations are exported large quantities of tobacco to other parts of China, to Yunnan, Hoo-nan, Han-Kow, and also to Se-fan in Thibet. To Han-Kow alone are annually exported about fifty thousand piculs,-say, about three thousand tons. The best is grown in the district of Pe-Heen : the next quality is the product of Kin-lang Heen; and an inferior kind is grown in the plantations of She-fang Heen.

Europeans who have visited this tobacco-producing district speak of a practice common among the inhabitants 
of rolling up tobacco for smoking in a separate leaf into cylindrical form, of the size of a large cigar. This simple circumstance is suggestive; it recalls to the memory what the first European adventurers in the New World have told us of the way the natives made up their herb for smoking. The Spaniards had observed the natives of Cuba and of Central America doing precisely the same thing; rolling up tobacco in a leaf of maize, or of the tobacco-plant, for smoking in the same way as do these denizens of the Flowery Land. And our countryman, Thomas Harriot, the historian of Raleigh's first colonists, in his Brief and True Report of the New Found Land of Virginia, says: "Soon after we made our peace with the natives we found them making a fume of a dried leaf, which they rolled up in a leaf of maize, of the bigness of a man's finger . . . putting a light to the leaf as they smoked it, as is done by all men in these days.' This identity of practice and habit points to a new link in the chain of evidence, connecting the inhabitants of the New World with the nations of eastern Asia, more particularly with China.

Bearing on the ethnological aspect of the subject is the fact that pipes have been found on many different occasions in the ancient earth-mounds of Ohio, in the valley of the
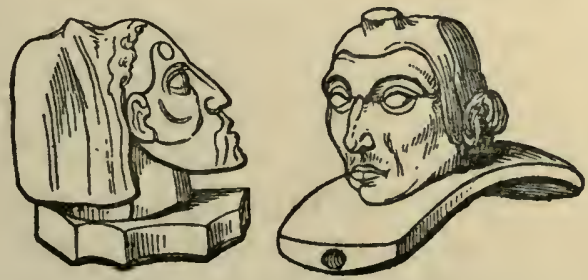

INDIAN PIPE-HEADS FOUND IN MOUND CITY, OHIO. 
Mississippi, and in Mexico, some of which are carved in the form of human heads of an unmistakably Mongolian type. Soon after the discovery of America the question of the origin of its inhabitants became a fertile source of conjecture among speculative thinkers. Probably Gregorio Garcia, a missionary who had for twenty years lived in South America, was the first to reject the general opinion that they were a new race of beings sprung from the soil they inhabited, and to suggest for them an Asiatic source. He published his views on the question in a work entitled The Origin of the Indians of the New World (Valencia, I607), wherein he expresses himself as opposed to the autochthonous character of the inhabitants, and points out reasons for thinking that the country had been peopled by Tartars and Chinese. Brerewood also, in his Diversities of Languages and Religions ( $163^{2-5}$ ), assigned the American people an Eastern, and chiefly Tartar, origin. But Hugh Grotius argued that North America was peopled from a Scandinavian stock, though probably the Peruvians were from China. Coming to more recent times may be mentioned Professor Smith Barton of Pennsylvania, who, in his New Vieres of the Origin of the Tribes and Nations of America, contends that they are descended from Asiatic nations, though he is unable to point to any particular source from which they have emanated. And John Delafield's Enquiries into the Origin of the Antiquities of America leàd him to the conclusion that the Mexicans were from the riper nations of Hindustan and Egypt, and that the more barbarous red men were from the Mongol stock. Alexander von Humboldt during his travels in South America gave the weight of his vast knowledge and shrewd observation to a consideration of the subject. In their habits of life, in 
their arts and leading ideas, and in their form of government, in their personal appearance-as the yellowish hue of their complexions and the Chinese cast of features, more particularly as noticed among the tribes of Peru and Brazilhe saw indubious evidence of an Asiatic origin. Everywhere he discerned indications, not of a primitive race, but of the scattered remnants of a civilisation early lost. It is to be earnestly hoped that an inquiry so full of deep interest may not be allowed to die out for want of organised effort to examine and establish the prehistoric connection of these early inhabitants of America with the Old World, possibly with the earliest dynasties of Egypt, before the ravages of time and advancing civilisation have effaced all traces. These traces are still visible and within reach; they are revealed in the buried cities of Central America, in elaborate inscriptions on the massive stonework of Mexico and Guatemala, and in other decorative masonry of a people who have left behind no other vestige of their existence, saving the outcast wanderers who still haunt the forest and prairie.

The question, then, naturally arises, may not the Chinese and other half civilized nations of Asia, in their prehistoric migrations to the shores of America, have carried with them not only a knowledge of the tobacco-plant and its use, but also the seed of the plant? Certainly they would do so at one period or another with such things as could be conveniently carried for the supply of their immediate wants. A knowledge and use of the tobacco-plant in China, before the days of Columbus, is established ; incidental mention is made of tobacco or some other plant that may be used in like manner,

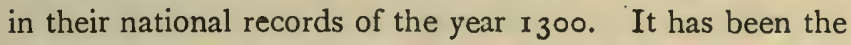
custom of every writer on the subject to decry all attempts to seek for the origin of the habit in any part of the Old 
World. Doctor Cleland, in his learned treatise on The History and Properties of Tobacco (Glasgow, r840), dismisses the inquiry as the growth of wild assertions by Eastern travellers, or, at best, a mere tradition of the people among whom they travelled, and 'obviously of no conceivable weight, from the love of antiquity which is so well known a mania of the inhabitants of oriental countries. This summary treatment may be convenient, but it is not convincing ; nor is it consistent with the open spirit of fair inquiry which would characterise all endeavour to arrive at truth, or to extend the sphere of knowledge.

After all, then, we find ourselves in presence of the not improbable hypothesis of an Eastern origin for the tobaccoplant and the habit of smoking its leaves. Let it be conceded that in this we have an instance, among many other of the Chinaman's way of forestalling the rest of mankind; that it was he who, long ages ago, first planted in American soil the perennial weed which Europe to-day presents to him as a new indulgence discovered by Western enterprise.

It must be borne in mind, however, that we have still to deal with another Eastern nation, namely Japan, whose history and associations are closely interwoven with the commerce, customs and culture of China. China in the past was to Japan what Greece in olden times was to Rome. The younger nation derived from the elder much of its knowledge in the arts and habits of life. Viewed in this light it seems altogether reasonable to suppose that if the tobacco plant and the practice of smoking its leaves were known in China before the discovery of America the Japanese would not be ignorant of these things. The question will be considered in the next chapter. 


\section{CHAPTER VII.}

\section{$\Lambda$ GLIMPSE OF SOCIAL LIFE IN JAPAN.}

Extending our survey to Japan we come among a people who interest us greatly in many ways. Their dress is neat and picturesque, their personal appearance pleasing, and closer acquaintance makes us feel well-disposed towards these children of the Rising Sun. For they are very polite and show great solicitude towards the Western stranger, and do all they can for his comfort. We observe with sympathy, and perhaps a touch of amusement, their primitive simplicity of manners and habits, which are all the more piquant because of their naturalness. Their native genius has in recent years revealed itself in a ready apprehension of immediate circumstances and in an intelligent adaptability to new conditions, as well as in wise forethought. Their devotion to duty and disregard of self when the honour and interests of their country are at stake shone out brilliantly during the great conflict now happily ended. But this brief observation would be incomplete without mention of the animating and sustaining principle of their religion, Shintoism. Their child-like belief in a spirit-world where their ancestors are looking down upon them cannot fail to influence them for good in every thought and deed.

We must go back six hundred years for the earliest European mention of Japan. In I 298, Marco Polo, at the 
end of his long wanderings in eastern countries, found himself a prisoner at Genoa. The enforced leisure brought him the happy thought that he would put in writing an account of his experiences. Of Japan he says, 'Zipangu is an island towards the East,' and adds, 'The inhabitants are civilized and well-favoured.' But Europe had not yet awakened to the glorious career of conquest and commerce which fate had in store for her. Two and a half centuries later the Portuguese explorer, Fernao Mendez Pinto, while cruising in Eastern waters bound for Macao, was driven by storm on to the Japanese coast near Nagasaki. The people with whom he came in contact were friendly and willing to barter for such things as he had for disposal. Tidings of the place and the people and of the favourable reception accorded him were not long in reaching the Portuguese at Goa and the Spaniards at Manila, and vessels laden with merchandise were speedily on their way to the new and promising mart of commerce.

With the Spanish expedition of I 549 came the good and pious Jesuit, Francis Xavier, full of zeal, bent upon the conversion of the natives to the true faith. On their arrival at the port of Bungo they were received with open arms by a people who seemed to know no guile. So favourably was the good missionary impressed that he exclaims in the narrative of his sojourn among them, ${ }^{*}$ "I have never found a nation among the infidels which has pleased me so much. They are men -ndowed with the best of dispositions, of excellent conduct, free from malice and gall. I know not when to have done when I speak of them. They are truly the delight of my heart.' And there is abundant evidence, speaking of the deep impression the saintly Xavier and his

* Japan and her People. By Andrew Steinmetz, 1860. 


\section{A GLIMPSE OF SOCIAL LIFE IN JAPAN II}

colleagues made upon the receptive minds of the gentle Japanese. For these good men had come to them well provided with medicines, and were not unskilled in the treatment of disease. Their untiring labours among the sick and needy, their sympathy with the poor and destitute won all hearts, and gratitude spread their praises throughout the land. The wise Shogun, Iyeyasu, was not unobservant or unmindful of his people's interests. Fully alive to the good work the strangers were doing he granted them permission to go where they pleased throughout his dominions. To the merchants also he granted similar privileges, allowing them to carry on unrestricted trade with the inhabitants. From the first the merchants had done well. As they unfolded package after package of their wares for inspection wonder waxed into childish delight, and the shredded leaves of the tobacco-plant which the sailors smoked in pipes was to these primitive people a revelation Fancy pictures the little people taking to the new indulgence with an amused twinkle in the eye like youngsters just come into possession of a new toy. And here we come upon evidence, full and convincing, that before the arrival of the Portuguese and Spaniards tobacco was unknown in Japan. Testimony to the foreign origin of the plant is borne by the people themselves, who knew no name for it and readily adopted the West Indian word 'tabaco.' It is remarkable that this Carib name, with slight variations in the spelling, should have spread to every country.

The story of Europe's early intercourse with Japan in regard to the conduct of both the Spaniards and Portuguese contains much that is painful and humiliating. For a few years the priests in the propagation of the gospel, and the merchants in their trade, prospered equally well. By-andby it became too glaringly apparent for even the simplest 
of the natives to mistake that they were being deceived and robbed by the strangers. The first serious mischief began in 1597. Xavier had left Japan for China, and his just and accomplished coadjutors had been succeeded by a host of Franciscans, Dominicans, Augustine and other friars who had flocked in from Goa, Malacca, Macao and other Portuguese settlements, all of whom commenced their career by setting the Japanese laws and usages at defiance. Speaking of the foreign traders, an old writer declares that they were by dishonest means rapidly draining away the golden marrow of Japan. And the progress made in proselytising is shown in the fact that within a few years of their arrival there were in Nagasaki alone no fewer than twelve parish churches and several monasteries, presided over by a bishop. Merited retribution, stern and swift, came in 1616 with the accession to the Shogunate of Hidetada, and eventually ended in 1637 in the total expulsion of the Portuguese and Spaniards from Japan. It is noteworthy that the Dutch residents sided with the Japanese and gave of their best and bravest during the prolonged sanguinary conflict.

A gleam of brighter vision breaks upon the scene when we touch upon the period which brought the first Englishman to Japan. The story of the Elizabethan mariner, William Adams, in relation to the place and the people, does something to redeem Europe's ill fame in that faraway land. He was a Kentish man, who, in his youth, had been apprenticed to a shipbuilder at Limehouse. At the end of the term he entered the Royal Navy as navigating officer. We next find him in his thirty-second year (1598) seized with an overmastering passion for foreign adventure. In the capacity of pilot-major he joined a Dutch merchant fleet of five vessels bound for the East Indies. Their 


\section{A GLIMPSE OF SOCIAL LIFE IN JAPAN I 21}

course lay by way of Cape Horn, in rounding which stormy seas scattered the ships. Two were lost, two found their way back to Holland, the remaining one called the Charity alone reached the far East. This latter was commanded by Adams. Tempest-tossed and worn-out, he, with his crew of twenty-four men were cast ashore on the Japanese island of Kiushiu, after a voyage which had lasted two years. He landed on Japanese soil on the r 9 th of April r600, and in such a plight that out of a crew of twentyfour Adams, in one of his letters home, says, "There were no more than six besides myself that could stand upon their feet.' They were taken to Osaka in order to give an account of themselves to the great Shogun, Iyeyasu. Adams speaks of the house in which the potentate dwelt as wonderful and costly, and gilded with gold in abundance. Called upon to declare his nationality and business he produced his charts and explained through an interpreter (doubtless a Portuguese), whence he had come, adding, 'We are a people that seek friendship with all nations.' The Portuguese, jealous of their interests in the island, represented the English and the Dutch as pirates living by plunder on the high seas, having no country of their own. At the close of the examination Adams was placed under arrest and detained thirty-nine days. He says that he was well treated. Something in his manner gained upon the Shogun; he gradually rose in favour, notwithstanding the efforts of his enemies to damage him and his country. Their motives were seen through; the sagacious Iyeyasu in a moment of exasperation declared that, 'if devils from hell visited his country they should be treated like angels from heaven so long as they behaved like gentlemen.' The Shogun was not slow in forming a just estimate of Adams. Indeed, his manly bearing and simple straight- 
forwardness gained him friends among high and low. We next hear of him at Court teaching Iyeyasu the craft of shipbuilding, the outcome of which was the construction of two ships on the European model. Adams says, 'Now

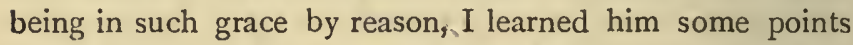
of geometry and the understanding of the art of mathematics, with other things. I pleased him so much that what I said he would not contrary.' It is pleasant to read of this manly Elizabethan sailor coming into honours and wealth in this far-off country by sheer native honesty of purpose and scholastic attainments. His royal master raised him to the rank of Samurai, and bestowed upon him an estate at Phebe, near Yokosuka. Richard Cocks, a merchant adventurer and member of the East India Company, describes the place, and says that it consisted of 'above one hundred farms or households, besides others under them, all of which are his vassals; and he hath power over them, they being his slaves; and he hath absolute power over them as any tono or King in Japan hath over his vassals.' Needless to say that the feudal system was then in full force in Japan. To the end of his life Adams maintained the character which had earned him this responsible position. Let us hope that three centuries after Iyeyasu the Great the Japanese discern in our people something of the same steadfastness that in those early days won their good-will. William Adams stood thus in favour when in 1609 two armed Dutch ships put into the harbour of Denzin. The commander sought out Adams, and, reminding him of his former connection with the Dutch merchant service, claimed his good offices for the advancement of Holland's commercial interests with Japan. No more was desired than a footing for trade such as had been granted to the Portuguese. So reasonable a request 


\section{A GLIMPSE OF SOCIAL LIFE IN JAPAN I2 3}

appealed to the fair-minded Englishman, and he readily gave his word to do what he could for thern. Again the Portuguese interfered and denounced the Dutch as heretics and outlaws from Christendom, and altogether untrustworthy. This calumny, however, had no effect. Adams succeeded in obtaining the desired privilege. But the distrust of all Europeans, created by the artifice and unscrupulous dealings of the Portuguese, led the Shogun to restrict the Dutch to the port at which they had landed. They, however, established a factory at Firando. Mr. W.E. Griffis in his admirable history of Japan, commenting upon the influence of the Dutch in that country, says, "After a hundred years of Christianity and' foreign intercourse the only apparent results of this contact with another religion and civilization were the adoption of gunpowder and firearms as weapons, and the use of tobacco and the habit of smoking.'

To round off the story of our countryman in Japan, it may be well to tell of the great yearning that came over him to return home to the wife and two children he had left at Limehouse. The Shogun, however, was loth to part with him, and his appeals for leave to do so, made, he says, 'according to nature and conscience,' were put off from time to time. When at last permission was granted, circumstances had arisen which prevented acceptance. Adams, however, was not unmindful of the interests of his native country. His desire to get into communication with England is shown in a letter which he addressed as follows :

'To my unknown friends and countrymen, desiring this letter by your good means, or news, or copy of this, may come into the hands of one or more of my acquaintances in Limehouse, or elsewhere, or in Kent, in Gillingham by 
Rochester.' His description of Japanese character might have been written to-day, so well does it accord with our present knowledge of the inhabitants of the Great Britain of the East. Adams says, "The people of this Island of Japan are of good nature, courteous above measure, and valiant in war; their justice is severely executed without any partiality upon transgressors of the law. They are governed in great civility: I mean not a land better governed in the world by civil policy.' In October, I6I I, he addressed a letter to 'The Worshipful Company of London Merchants,' urging them to send merchandise to the ports of Japan. In the simple words of a sailor he tells them that he is a 'Kentish man, born in a town called Gillingham, two English miles from Rochester and one mile from Chatham, where the Queen's ships do lie.' Before the letter reached them they had heard through the Dutch of Adams and his position in Japan, and had sent him letters, advising him of their intention to despatch goods to Japan. In April, $16 \mathrm{r} 2$, three English vessels laden with merchandise, and commanded by Captain John Saris, sailed from the London Docks for the far East. They arrived at Bantam (Java) in October of the same year. How little time was reckoned with in those days is shown in the circumstance that Saris thought well to remain at Bantam until the beginning of the following year, knowing all the while that he bore a letter from King James to the Emperor of Japan. He sailed in the Clove with a crew of seventy, and sighting the coast near Nagasaki, he, two days later, anchored in the haven of Firando. Here Adams met him and arranged for a visit to the Shogun, who was then at Sumpu. Thither they repaired, accompanied by a Japanese interpreter and two followers. They carried with them presents to the value of 720 dollars for Iyeyasu and the State officers. They started on their 


\section{A GLIMPSE OF SOCIAL LIFE IN JAPAN I 25}

journey on the 7 th of August, and arrived at their destination on the 6th of September. On the 8th they had an audience of the Shogun, to whom they delivered the English King's letter for the Emperor. They were graciously received, and Iyeyasu in return sent to King James five screens and a letter for His Majesty, conveying a free licence to English subjects to enter any of the ports of Japan for trade purposes. Thus was established in the year 1613 the first treaty of commerce between England and Japan.

In the midst of all these things our hero had met with a fair damsel in Japan with whom he mated, and who bore him a son and a daughter-Joseph and Susanna. And, to complete the romance, we are itold that there are to-day Japanese who pride themselves on being able to trace their descent from this Elizabethan mariner whom the greatest of their Shoguns loved to honour.*

In Japan, however, as in other countries into which the Indian weed had been introduced, it was not allowed to take root and flourish unopposed. Protests, strong and loud, were got up by the old-fashioned folk against the new-fangled indulgence from the 'Nanban'-country of the southern barbarians. So strenuously did they proclaim it to be the 'fool's plant,' the 'poverty weed,' the 'barbarian's herb,' that at last they won over the Shogun to their side. In I6I2 he issued an edict forbidding his subjects to either use tobacco or to plant seeds of it. It is curious to notice how, in this remote region, the witchery of the weed set good men and true warring over its virtues or vices on exactly the same lines as were being fought over at the same time in England, and in each case with a precisely similar result. Like the

* Adams died full of honours in 1620 , and was buried on the summit of a little hill at the end of an inlet called Goldsborough. 
historic Counterblaste of our British Solomon and the fulminations of two popes, their efforts to put out the pipe were unavailing. Indeed, as usually happens in conflicts of the kind, opposition begat opposition, till at last the will of the many triumphed over the prejudice and power of the few. The people had tasted the forbidden leaf and liked it so well that each offered to share with his neighbour the pleasure and, if need be, the punishment attached to the indulgence. So in course of time the edict died a natural death, and was decently buried under a mild ceremonial wherein the Shogun enjoined his loving subjects to be careful and not let themselves be seen smoking outside their houses. Rein, in his Industries of Japan, says of this edict, ' of all the laws of the Tokugawa rule probably none has proved so ineffectual as the edict of 1612 against the smoking and planting of tobacco.'

The earliest native record of tobacco is found in an old family chronicle of an eminent physician named Saka, of Nagasaki; it is dated 1605 , and runs as follows: 'In this year tobacco was brought in ships of the Nanban people, and was shown near Nagasaki ; it was known in Bungo (the Portuguese settlement) from the beginning and in Sasuma 'a district noted to this day for the superior quality of its tobacco. A further note on the subject occurs two years later, 1607 , and is to the effect that, 'of late a thing has come into fashion called tabako; it is said to have originated out of the Nanban, and consists of large leaves which are cut up, and of which one drinks the smoke.' In the same record incidental allusion is made to the supposed medicinal properties of the Indian weed, a notion derived from the natives of America and propagated in Europe with much insistence by Jean Nicot. The writer is never weary of chronicling the fact that, 'a thing has been coming out of the Nanban 
called tabako, with which all classes of Japanese regale themselves. It is said to be a cure for all diseases; but, notwithstanding this, some people have got sick through drinking the smoke. Now, since no medical work contains directions for the treatment of such patients, no medicine for their relief could be offered them.'

The distinguished writer, Kaibard, protested loudly against the barbarian novelty ; he compares it with tea and with saké - a beer made from rice-and roundly condemns tobaccosmoking, saying, that far from yielding benefit to anyone it injures the consumer in many ways. It is not worth while, he considers, to chide the common people for smoking, but he expresses surprise and indignation that gentlemen and superior persons should take pleasure in a custom imported from over the seas and taught them by strangers. On the other hand, a learned treatise called 'Ensauki,' translated by Sir Ernest Satow, enumerates some of the excellences discovered in the weed. These are :

(I) It dispels the vapours and increases the energies.

(2) It is good to produce at the beginning of a feast.

(3) It is a companion in solitude.

(4) It affords an excuse for resting now and then from work, as if in order to take breath.

(5) It is a storehouse of reflection, and gives time for the fumes of wrath to disperse.

But on the other hand are objections to its use such as the following :

(I) There is a natural tendency to hit people over the head with one's pipe in a fit of anger.

(2) The pipe comes sometimes to be used for arranging the burning charcoal in the hibacki.

(3) An inveterate smoker has been known to walk 
among the dishes at a feast with the pipe in his mouth [the dishes resting on mats ranged along the floor].

(4) People knock the ashes out of their pipes while still alight and forget to extinguish the fire; hence clothing and mats are frequently scorched by burning ash.

(5) Smokers spit indiscriminately in the hibacki, foot warmers, or. kitchen fire; also, in the crevices between the tatami which covers the floor.

(6) They rap the pipe violently on the edge of the firepot.

(7) They forget to have the ash-pot emptied till it is full to overflowing.

It is easy to see how pointed admonitions such as these, thrown broadcast upon Japanese smokers, would yield a handsome crop of good manners. The Japanese are, and have always ranked among, the foremost of polite peoplea grace natural to their fine sensibility. Rather than hit his friend over the head with his pipe in a fit of temper, the valiant Japanese will put his fingers into the burning hi-ire in order to change the venue of his annoyance. A trait of their child-like character comes well into view in a story told of one, Oka, a famous judge, whose book of anecdotes and wise decisions Sir Ernest Satow has rendered into English. The work is entitled Oka Inseidan, and the story is of,

\section{'The Theft of the Golden Pipe.'}

Once upon a time a wealthy man was the happy owner of a rich and rare kiseru (tobacco pipe) made of silver, inlaid with gold and precious stones. It happened on one occasion, after calling to his servants to bring him the tobacco-bon that he might indulge in a breath of fragrance from his treasured kiseru, that he was told the pipe was 
gone, and no one knew whither. Search was made for it high and low, in likely and unlikely places, but all in vain. Then did they remember their renowned Oka, the wise. They appealed to him for counsel, and made him acquainted with the cause of their grief. $\mathrm{He}$, shrewd man, questioned the household, and on learning that a poor fellow living in the neighbourhood had been seen smoking a pipe of great

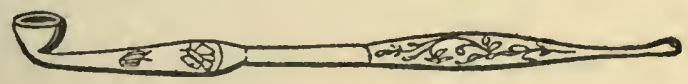

\section{A JAPANESE PIPE.}

value he found out the truth respecting it in the following ingenious manner. But here, in order to better understand the story, it will be well to explain the Japanese method of smoking. It is the custom of each smoker to roll the tobacco between his fingers into a ball of the exact size required to fit the bowl of the pipe, so that when turning the pipe sideways to light it at the live charcoal it should not fall out; after every two or three whiffs a fresh ball is introduced. The smoker-will thus occupy himself by the hour listlessly making freslı ones while he smokes, utterly oblivious it may be to what he is doing, but from constant practice his nimble fingers with automatic precision invariably makes the tiny ball of the size needed to fix it securely in the bowl. And now, let us hearken to the words of Oka, and learn of the sage how he recovered the lost pipe and brought the culprit to justice. 'Unseen by the suspected one, I found out a way of watching him while seated on his mat idly toying with a pipe. Snugly hidden behind a paper screen I made slits in it for my eyes, for thought I, if the pipe be not his own he will make up tobacco balls too large or too small to fit the bowl, then shall I know the 
truth. Thus ensconced, peering through the holes I had made for my eyes, I beheld in the man's hands a pipe of surpassing beauty. I saw that he took from his tobacco. pouch some shreds of the weed and rolled them up, and in blissful ignorance of other eyes than his own to see and admire his chased kiseru he caressingly handled it, and fed it with the pabulum of peace. But when he bent forward to the brazier and turned the bowl on one side to catch a light from the live coal the little ball of tobacco fell outit was too small for the bowl! Again and again this same thing happened.' Then did Oka reveal himself to the already convicted felon and charge him with the theft, saying, ' $\mathrm{Had}$ the pipe been thine own, $\mathrm{O}$ son of infamy, long and constant usage would have taught thy fingers to make up the tobacco balls of the size needed to fit the bowl.' This process of reasoning was conclusive. The culprit was taken before the tribunal of justice and punished according to the enormity of his offence. That no shadow of unworthy doubt may rest upon the seat of wisdom, the veracious chronicler adds, that when the unhappy man was formally charged with the crime, he, with deep humility confessed his guilt; whereupon the judge restored to the rightful owner the lost golden pipe, and the fame of Oka, the wise spread throughout the land.

To-day the smoking of tobacco in Japan is universal; so completely has the practice entered into the daily habits of Japanese life that high and low, rich and poor-and of both sexes-have come to look upon the introduction of the tabako-bon-containing all their curious smoking apparatuson the occasion of the arrival of a visitor, as a social function which could not be neglected without giving offence. Even in the poorest man's house the tobacco tray, with its fire-pot and ash-pot, is an essential part of the 
furniture. Visit the humblest abode and there will be placed before you all the tiny equipment for a smoke; but their weed is almost tasteless; certainly, it can do nobody any harm. Formerly the tiny cup of tea was always the prelude to social gossip; now, however, for some reason or other the pipe takes precedence of the cup. Surely a wise choice, for in the pipe he had found a soother of the ruffled frame, calming the unruly member which the teacup sets free to dilate with eloquence on the virtues-or their opposite- of the dear absent ones; helping the fair devotee to unbosom herself of old confidences too heavy to be longer borne, and to form new and undying friendshipstill the next tea meeting. Assuredly, wherever Eve's daughters congregate there will the tea-pot-the genius of quickened sensibilities-be the favourite fetish.

Let us take a peep at a reception, an 'At Home,' where a dark-eyed daughter of Japan reposes luxuriantly on a carpet of many colours. By her side is an arm-rest, and a gorgeous screen adorned with wondrous figures in prismatic hues protects her from obtrusive view. Two English ladies are her visitors; they are ushered through a long corridor, covered with thick matting of a fine texture, into the reception hall. Passing into a large wellproportioned room, they are agreeably surprised with the simplicity and tasteful character of the furniture, which consists of a row of small lacquer tables and chairs, placed at intervals of a few yards; by the side of each chair is a large bronze urn of ornamental design, filled with symmetrically shaped pieces of glowing charcoal. Raising the eyes to the walls they see that these are covered with a heavy yet delicate paper artistically painted with birds and flowers; and the wainscoting, panels and window-frames, are of a highly polished black lacquer. Over all there 
seems to hang a drowsy luxurious atmosphere, quite in keeping with the old-world ease and courtly manners of their truly polite hostess. Meanwhile female servants have noiselessly placed before them the tabako.bon, upon which rests a gold-dotted lacquered case, delicately made of leather-paper; it is about eighteen inches long, and twelve broad, and stands the height of three fingers. On the removal of the lid the first things which strike the eye are three chased little tobacco-pipes, each enclosed in a silk lined case, which in form so nearly resembles the calausilia that it is called the kiseru-gai-pipe snail. The bowl of the pipe is a fairy-like thing of the size and shape of an acorn-cup, and is of finely wrought silver; the stem, about six inches long, is of thin lacquered bamboo, and the mouthpiece is of brightly polished metal. The pouch holding the tobacco is also of stamped leather, and is finely decorated with lacquer and silver work. But the tobacco is something wonderful; though an exotic of the genus nicotina-tobacum of America, it has cast off its native characteristics and become a light-coloured delicate weed, which lissome fingers have cut into flossy shreds as fine as gossamer and as soft as cocoon silk. As the usages of polite society in Japan require that the visitors should smoke while chatting, the hostess taking a few shreds of the weed between her fingers and rolling them up into pellets to fit the tiny bowls urges her guests to join in the grateful pastime. One of the ladies, however, declines the proffered pipe, saying, 'Arigato, tabako-o nomimasen,' (thank you, I don't drink tobacco) at which the hostess with wondering eyes asks if she is under a vow! She thinks that ladies everywhere smoke; that to do so is a binding rule of the unwritten law of social intercourse. But on the other guest accepting a pipe, saying, 'tabako-o nomimas,' (I 


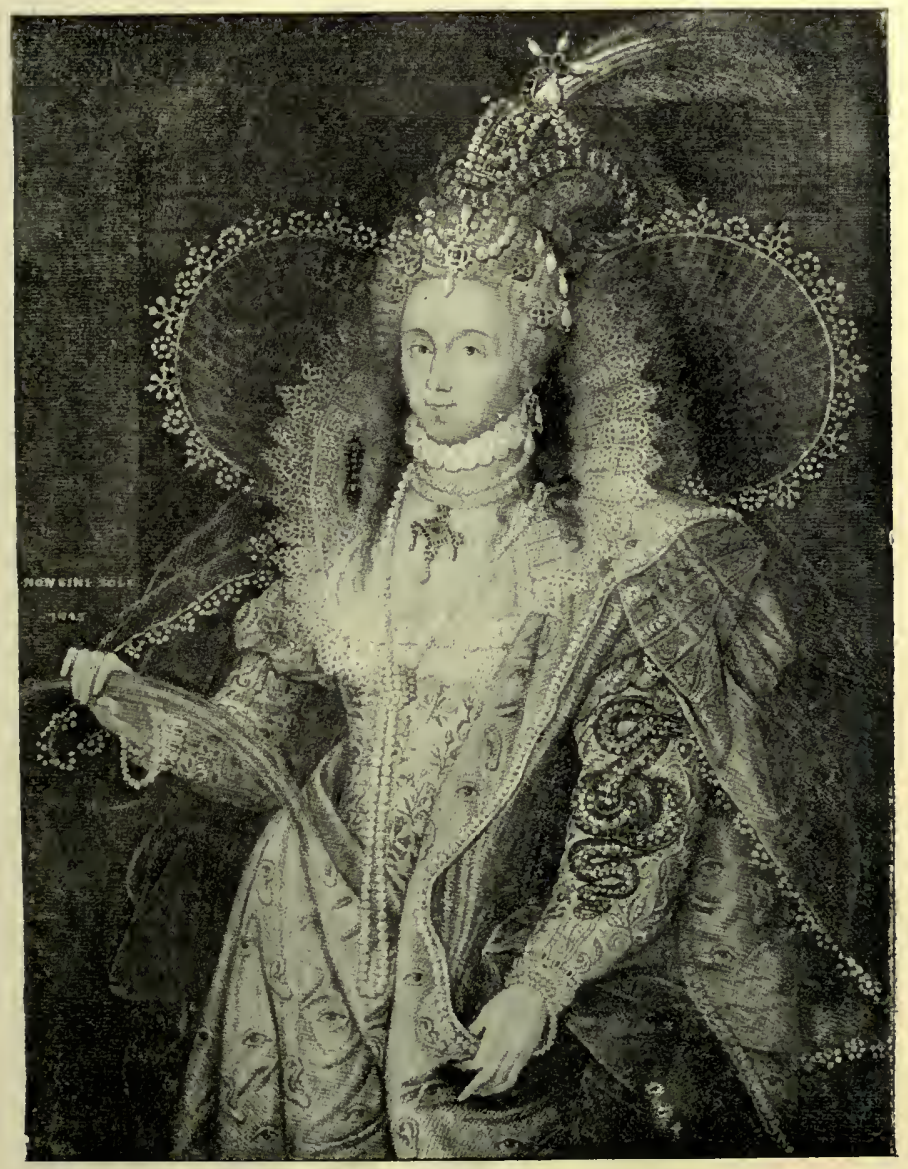

Queex ElizabeTh. 

drink tobacco) the charming hostess nods and laughs, and with her own delicate fingers tries her best to light the pipe with an English match, and only after repeated attempts can she accomplish the difficult feat. While thus occupied a sprightly, intelligent, little gentleman enters, and is introduced as the husband of the hostess. He is brimful of Western ideas, and readily joins his wife in ceaseless questions concerning England and the English; more particularly he seeks information about the habits, manners and government of the country; for he is most anxious to learn whether what he has just heard in the city is really true, namely: that in England no gentleman is allowed to smoke in the presence of a lady without first obtaining her permission. He cannot credit it, but he explains that the question is greatly perturbing men's minds in Japan. It is feared that if this Western custom should spread and take root amongst them, men's authority over women would be gone; certainly their pre-eminence would be seriously imperilled. The visitors try to reassure him. They tell him that as a rule gentlemen do pay this deference to ladies out of considerations of delicacy, as behoves men towards women, as well as from a chivalric regard for ladies generally. But this was a line of argument he seemed unable to follow; he was dominated with the idea that the custom if adopted in Japan would be the thin end of the wedge which ultimately would sever men from their proper control over their wives and women-folk generally. With a countenance expressive of perplexity and dismay he foretold of endless domestic storms issuing from the fuming pipe. It was not without amusement that the English ladies witnessed this curious reflex of a Western spectre which a few idle people have raised for their diversion, and it required some effort to suppress their feelings. They did their best, how- 
ever, to smother the emotion; but the spectacle presented to their imagination of wives boxing their husbands' ears for daring to smoke in their presence without leave, and all the varied scenes of the battle of the pipes fought over the domestic hearth, was too much for them. Warming to the subject the bellicose little gentleman exclaimed, 'The enemy outside our gates we can grapple with and overthrow, but a Western idea, and a fickle one like this, who can seize and vanquish? I have myself but recently suffered through this innovation, but it shall be the last time.' And he so far forgot his native politeness as to declare that he would smoke when and where he pleased, and if the ladies did not like it they might leave the room. He added, 'I do so in virtue of my right as a man. The assumed right of the women in Europe to determine whether a man may smoke or not is an unwarrantable licence, and is all put 'on in order to bring men under their authority in other and more important affairs; in any case, it subtracts from the power of men, and there can surely be no reason in this, as it involves limitations to their authority which must inevitably provoke confusion and confict. I can find no reason for making distinctions-for smoking before men and not before women when it is not a thing forbidden by law or morals.' The ladies endeavoured to soothe the ruffled feelings of their irate host; they assured him that nothing is farther from the thoughts of intelligent gentlewomen than the folly of trying to subvert the order of nature; that the deference paid to ladies in such matters by their kinsmen is the outcome of good breeding, and it is always appreciated in that sense. "There are a few women, perhaps, who having much time and little to do make it their hobby to cry out for the unattainable, and whom the gods may some day punish by giving them what 
they crave for ; but these women are of no account in the general estimate of the sum of Western domestic life; their voices are loud, but their judgment is weak. On the other hand, there are in Europe ladies of the highest rank who, out of pure love of doing good, devote the best part of their lives and fortunes to the noble purpose of relieving the needs of the destitute, and raising the lowly and suffering into better estate. Little room then for wonder that Englishmen are proud to do them honour.' Though appeased in some measure, he was not wholly convinced that danger was not somewhere lurking in their alluring argument. Let it be noted, however, that young Japan is outgrowing such apprehensions; he is no longer restive under the restraints imposed upon his primitive habits, and his conception of the relationship of the sexes is in accord with European ideas. Western ideas, indeed, are his ideas; and, he shows how fully he recognises the superiority of European civilization, by equipping himself with all the most destructive engines of warfare.

Like the workmen of the busy cities, the Japanese peasant carries with him wherever he goes his pipe and tobacco-pouch slung to his obi, a bright-coloured girdle, made usually of a peculiar kind of silk interwoven with flowers. They hang behind, suspended from a silken cord fastened to the obi by means of a netzuke-a sort of carved button made of cornelian or agate. Unfortunately, or perhaps fortunately, their peculiar smoking apparatus does not lend itself readily to indulgence while at work or when walking. To enjoy the solace of the weed, the smoker must squat on the ground and array his smoking utensils in order; but this little drawback seldom hinders him. When the desire for the pipe comes upon him it must be appeased; and is it not 
written in the learned Ensauki that the pipe 'affords an excuse for resting now and then from work, as if to take breath ?' Certainly, the intelligent Japanese never suffers an opportunity to pass unimproved by rest and reflection over the vapour of his beloved pipe as it ascends on high, mingling with the pure breath of heaven; while possibly the lingering ashes suggest to his contemplative mind the mutability of all things earthly-for who can price for another the thing which his soul valueth ?

Passing along the unbeaten tracks of Japan the wayfarer from the West occasionally comes upon picturesque scenes of peasant life of a character which combine primitive simplicity of manners with something of the art and refinement of what we are accustomed to associate with advanced civilization, but which with them springs from a gentle, susceptible nature, always kindly, but quick to resent affront. Turning into a roadside inn he may meet with a party of well-to-do peasants on their homeward way from the market of a neighbouring town, and observe with quiet amazement the public exhibition they make over the bath; they are very fond of bathing, but in their manner of using the tub they have views peculiar to themselves. Fish and rice are in large demand, and of these, with a plentiful supply of vegetables, they make a hearty meal. After dinner tiny cups of tea are served to each guest by dark-eyed damsels whose appearance recalls to memory the nursery pictures of our childhood representing our first parents in the garden of Eden. When the candles are brought in smoking and story-telling follow till bed-time. Then, spreading blankets on the floor, and with a block of wood hollowed to fit the head for a pillow, they are soon on their way to the land of Nod, announcing their arrival in a fine symphony of cracked bassoons. 
As everybody smokes in Japan the rate of consumption per head of the population is considerably greater than with us. And shops for the sale of tobacco and all its accessories are to be seen in every street in the big towns, and in every village which has shops at all; even along the country roads there are stands where all these things can be had for the merest trifle. On the sign the tobacconist exhibits to denote his vocation is painted a leaf of the plant, and by the side there are two hieroglyphics which are understood to intimate that he keeps only the best tobacco, procured from the famous kokubu in the Osumi district. The name bears a significance similar to that of Virginia with us. But the taste of the weed grown in this favoured district is not such as commends itself to English smokers; it is too sweet, and on this account is but little exported to Europe. It is used here for mixing with other kinds of a more pungent character: French tobacco would be all the better for the admixture. But to do this in France, where the cultivation, manufacture and sale of tobacco is a Government monopoly, would perhaps interfere with the public revenue.

The Japanese method of raising crops of tobacco, of curing and manufacture, is in all essentials similar to that of other countries where tobacco-culture is a staple industry. The seed-beds of the young plants are protected against too great cooling from radiation on spring nights by straw roofs about a metre high. Towards the end of April, in the warmer districts, the shoots are strong enough to be transplanted into the open fields, where they are placed in rows usually along the sides of crops of barley which by this time has passed its bloom. In cooler districts this operation is delayed until June. But, as tobaccoculture is widely spread throughout the islands, the seasons 
for planting and reaping necessarily differ according to the varying temperatures of this plutonic region of sulphurous springs and earthquakes. Besides the pleasure of smoking, the Japanese, like ourselves, have found many uses for tobacco. For destroying insects on plants, nothing is so effectual as dosing them with a liberal decoction of the juice. Like all other orientals the Japanese have to wage perpetual warfare with those plagues of the flesh that invade every house. In order to check their ravages, he places leaves of the plant in crevices where they usually hide in ambush against the hour for making their nocturnal attack. Mosquitoes, too, are numerous, hungry, and of good size, but in the magic breath of the weed he has found a potent spell which soon overcomes the enemy and lays him low. All he finds it needful to do, is simply to seat himself on his mat in his toy-like house and enjoy the double pleasure of knowing that he is vanquishing the foe while puffing his wee pipe and twirling up pellets to fit the thimble-like bowl. He has discovered, too, that Saint Nicotine is a dispenser of other inestimable blessings. As a healer of many maladies -cutaneous affections, some forms of eye disease, and other like disturbers of a tranquil life-he believes in her implicity, and lotions made of the juice extracted from the leaves of the plant are in almost daily use among the poorer classes.

Young Japan having entered with a light heart and buoyant into the stream of European life no longer cares for the old ways of his fathers, and finds his chosen smoke in the new paper cigarette fashioned in the Western world. Of these he partakes so liberally that many millions are imported every year, the total value of which, according to the Consular Report, comes to about $£ 40,000$. To such proportions has the tobacco industry grown that in Osaka (the 
Manchester of Japan) no fewer than forty factories provide remunerative employment for thousands of work-peoplechiefly women and girls. In I895 Japan exported close upon three million pounds weight of tobacco, the estimated value of which was $£^{2} 3,466$. Under the influence of an overmastering passion to mould their institutions on the model of those of Europe, the Government have thought well to lay hands upon the tobacco industry; henceforward it is to be a Government monopoly. Referring to the Japanese Bndget of $1897-8$, Sir Ernest Satow, in the Diplomatic and Consular Report on Trade and Finance for the fiscal year $1897-8$, discusses the question. The Bill was passed in the session of 1896 , and the monopoly is to come into force at the beginning of 1898 . The principle of the scheme is, that tobacco grown in Japan shall be delivered in the leaf to the Government at a fixed rate. The Government will then sell it to the manufacturers at rates which will ensure substantial relief to the depleted exchequer, to the extent, possibly, after all expenses of collection, etc. are met, of about half a million sterling. The annual yield of the tobacco fields of Japan is estimated at $90,000,000$ lbs., its

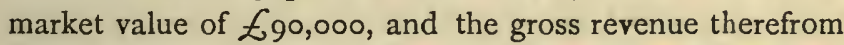
at $£ \mathrm{I}, 000,000$. Here Sir Ernest Satow's incisive criticism comes into play. He shows that to realize this sum a tax of over 100 per cent. must be levied, and that this would bring up the price to the consumer to double what it is now. He points out that tobacco leaf can be imported into Japan at roc. per lb., add to this the import duty, namely 35 per cent., and the result will be that the Government will try to sell its tobacco at $21 \frac{1}{9} \mathrm{c}$. and this, too, in face of the fact that imported tobacco can be sold for I $3.5 \mathrm{c}$. per lb. There is a further important consideration telling against the Government scheme, namely: that as the tobacco intended for ex. 
portation does not come under the monopoly the producer can send his unmanufactured leaf out of the country, have it prepared for use and brought in again ready for the retail dealer, and still compete successfully with the Government. Sir Ernest adds that, "Were the simple system adopted, in operation in England, of warehousing, it is estimated that with the same tax a revenue of at least $£ \mathrm{r}, 000,000$ could be obtained.' The monopoly scheme was severely criticised in the Senate, and it was thought that it would be amended, but up to the date of Sir Ernest's report nothing had been done in this direction.

The marvellous transformation which has taken place in Japan within the last thirty-five years has hardly left a vestige behind of the old order of things which so charmed the eyes of the stranger from the West. Even in the remote villages the peasantry, as if ashamed to be themselves, are entering upon new paths and disguising their primitive habits of social life under the garb of Western modes and manners. The graceful native costume is supplanted by the distortions of dress which the caprice of art sends forth from Paris as if to render humanity ridiculous. It is not a pleasing sight to look upon Japanese ladies enduring torture in their efforts to accommodate themselves to Western fashion and finery. And the men, skewered up in sombre broad-cloth, lose the ease and dignity which by nature's gift is theirs. Would it not be well, while gathering the fruits of old European culture, for this Eastern people to preserve their native habits, works and ways, all those things which are the natural product of their race and climate? Of course, in commerce, the observance of the eternal verities, as Carlyle would say, forms the basis of all healthy and lasting good.

There is, however, one cheerful sign in the present-day habits of this most interesting people: through all the toils 


\section{ANTIQUITY OF TOBACCO-SMOKING I4I}

and vicissitudes of their new and exalted path in life they resolutely keep the pipe aglow, mindful of the wise words of the Ensauki that in the vapour of the fragrant weed is a storehouse of reflection where the fumes of anger are suffered to disperse. 


\section{CHAPTER VIII.}

STRAY LEAVES FROM THE INDIAN WEED.

The pungent, nose-refreshing weed, Which, whether pulverised, it gain A speedy passage to the brain, Or, whether touched with fire, it rise In circling eddies to the skies, Does thought more quicken and refine Than all the breath of all the nine.

COWPER.

How dearly the late Poet Laureate, Tennyson, treasured his briar-root; how with his 'silent friend' he would seek seclusion, drawing unfailing solace from an inexhaustible tobacco jar, belongs to the social history of our times. In the fulness of their hearts, lovers of the weed have declared that in it they have found 'the only thing in life that fumes without fretting.' If to this excellence be added the further one of assuaging the fretful, we shall have the whole philosophy of smoking in a nutshell. Because of these rare virtues paterfamilias will now and then forego the social distinction of occupying the paternal chair that he may enjoy the comforts of a quiet pipe away from all the blessed cherubs of domesticity. For these, the idolised bachelor, weary of loving attentions (the ungrateful being!) will watch his opportunity for flight, and slipping away unseen, will make off 
to his favourite hiding-place. Briskly entering his den he surveys with twinkling eye his own undisputed domain, with pipe-rack and weeds, benches and books, rifle and rod, all in undisturbed (dis)order. Tenderly he handles his favour. ite calumet, bestows the pabulum of peace, and awaits the sweet solace which will soon dispel the worries and passions born of strife in life's warfare.

Many an over-wrought brain has thus received the balm that stays the rash hand or the fevered spirit from hurrying to a reckless end. Surely no one need wonder at the smoker's devotion to his pipe, nor be so uncharitable as to class his troubles and trials and their happy deliverance with the mere fancies of a lazy man in search of excuse for an idle habit. Let us not be hard on the smoker. Do we not all know men who would fain indulge in a social whiff now and then with their friends were it not for the warnings of an inward monitor who will not be trifled with? The man who had conquered Europe was himself conquered by a pipe of tobacco. An oriental pipe of wonderful beauty and inventive skill was presented to Napoleon by a Persian ambassador. Though he was an immoderate snuff-taker he had never smoked, but he would try this pipe. It was duly charged with tobacco and lighted, says Constant, but His Majesty, instead of drawing up the smoke in the usual way, merely opened and shut his mouth with mechanical regularity. Losing patience, he exclaimed, 'Devils! There is no result!' It was remarked that he had made the attempt badly, and he was shown how to smoke properly. But the Emperor simply reverted to his automatic performance; the pipe went out, and Constant was desired to relight it. This done, he again instructed his master in the proper method of smoking. Determined not to be balked again, the Emperor resolutely drew up the 
smoke, and, swallowing it, it came out by his nostrils and blinded him. As soon as he recovered breath he cried out, 'Away with it! Oh, the hog! Oh, my stomach! My stomach turns!' This was Napoleon's first and last experience of smoking. Then let those whom St Nicotine favours thankfully own her benign sway and be comforted. The placid oriental, when his wives rave, or affliction smites him, will stroke his beard-if he have one-and thank Allah for the good gift

Which on the Moslem's ottoman divides,

His hours, and rivals opium and his brides.

An old Persian legend, brought to light by Lieutenant Walpole, tells the story of a virtuous youth distraught at the loss of a loving wife. A holy man looks tenderly upon the disconsolate one, and tells him of a balm for his affliction. 'Go to thy wife's tomb, son of sorrow,' says the anchorite, 'and there thou wilt find a weed. Pluck it, place it in a reed, and put fire to it, then inhale the smoke thereof. This will be to thee wife and mother, father and brother, and, above all, will be a wise counsellor, and teach thy soul wisdom and thy spirit joy.' The Homeric strain of this Eastern sage breathes of implicit faith in his native Shiraz tobacco. For doubtless he, a dweller in

. . . . the land where the cypress and myrtle Are emblems of deeds that are done in their clime; Where the rage of the vulture, the love of the turtle, Now melts into sorrow, now maddens to crime, had often experienced its influence on a wounded heart. Indeed, the history and associations of the plant, from its wild Indian home to the remotest East, are full of romance of more than ordinary interest. For, like most things transatlantic, whether products of the soil or of the brain, it 
rapidly became universal, spreading literally like wild-fire wherever man was to be found. Everywhere it was esteemed a close comfort, a priceless possession, and to its rare qualities were ascribed almost miraculous powers. The persistency with which men have stuck to the weed, after once experiencing its soothing effects, ranks among the most remarkable examples history affords of the rapid development of a new taste and the formation of a new habit; a habit that, after the lapse of three centuries and more, grows stronger day by day, keeping full pace with the increase of population, until now it is too deeply rooted ever to be extirpated, even by taxation, however weighty. Viewed in its political aspect, the career of the Indian weed presents a striking illustration of popular opinion ultimately triumphing over prejudice and power.

Here let us take a cursory glance back to the heroic age when the marvellous weed which has almost revolutionised men's habits all over the world, and created a new industry giving employment to millions of human beings, was first imported into these islands.

A halo of romance surrounds those jubilant days ; but, in the eyes of Englishmen generally, Sir Walter Raleigh stands out prominently as the hero to whom the honour is due of giving his countrymen their first instalment of tobacco. England had just awakened to the reality of a new world of wonders and boundless wealth lying unexplored in the far West; a land where everything touched turned to gold. The far-famed discoveries and conquests of the Spaniards, their fabled El Dorado, drew forth the daring and enterprising from every corner of Europe. Stirred by an overpowering desire to see the marvels, and share in the treasures of the terra incognita which was in all men's mouths, our hardy sea captains, Hawkins, Drake, Raleigh, 
and a host more of England's sturdy sons, sailed the Spanish main, bent upon achieving fame or fortune, yet caring little what lot befell them if only renown were won for their idolised Queen Bess. They encountered the mild Indian, and explored a portion of his glorious land, teeming with a rich luxuriance of vegetation such as their eyes had never before beheld. But what of El Dorado, the famed city of gold and precious stones, hemmed in by golden mountains, whose splendour and immense treasure beckoned them onward? Alas ! the gorgeous phantasm of the New World, like the glories of the setting sun, melted away before their advancing steps. And yet many a poor, dispirited wayfarer in the pursuit of the alluring ignis fatuus found comfort and consolation in the humble weed which the natives supplied to him and taught him how to use. In testimony whereof, listen to honest Jack Brimblecombe in Westward Ho! 'Heaven forgive me! but when I get the leaf between my teeth, I feel tempted to sit as still as a chimney and smoke to my dying day.' And faithful old Yeo pours forth his pent-up gratitude for the comfort he derives from the Indians' herb in a stream of consolation for the lonely and afflicted, assuring us that when all things were made none was made better than this. And here he enumerates the blessing breathed upon the weary and worn traveller in those far-off lands by the herb, like unto which there is not another under the canopy of heaven.

In the summer of 1584 , Raleigh, his imagination aglow with brilliant colonisation schemes which should eclipse those of Spain, sent out an expedition to explore the coast of the new continent. On July r3, the party, under Captains Amadas and Barlowe, took possession of the territory which Raleigh subsequently named Virginia, in 
honour of the Queen. In the following year a second expedition was despatched, conveying one hundred and seven souls, whom, with Master Ralph Lane at their head as the governor of the new colony, Raleigh had inspired with his own ardent hopes and plans for the founding of a new settlement that should, in course of time, rival the Spanish conquests. The adventure, however, was not attended with the success anticipated. The party remained in the new territory from August $17, \mathrm{r}_{5} 85$, to June $18, \mathrm{r}_{5}^{86}$, when Sir Francis Drake, with his fleet, returning along the coast from his victorious raid in the West Indies, called at their port, and, learning their discontent, brought them back to England. They took care, however, not to return empty-handed; a large quantity of tobacco, which the natives had prepared for them, was stowed on board the vessels, with a variety of instruments for preparing and using it. It can well be imagined that Master Lane would take pride in exhibiting himself to London's gazing multitude smothered in Indian clouds. The learned Camden speaks of Lane as the original English smoker. It is remarkable that there should have been so much uncertainty, even in Eliza-Jacobean times, as to the date when tobacco was first received in this country and the person by whom it was first introduced. The painstaking annalist, Stow, says that tobacco came into England about the twentieth year of Queen Elizabeth (1577). But Aubrey, speaking of Sir Walter Raleigh, says that 'he was the first that brought tobacco into England and into fashion (1686). In our part of North Wilts-e.g. Malmesbury Hundred-it came first into fashion by Sir Walter Long. They had first silver pipes. The ordinary sort made use of a walnut shell and a straw. I have heard my grandfather, Lyle, say that one pipe was handed from man to man 
round the table. Sir Walter Raleigh, standing in a stand at Sir Ro. Poyntz parke at Acton, took a pipe of tobacco, which made the ladies quitte it till he had donne.' The author of a gossipy Tour in Wales (Pennant), in r8ro, speaking about the great houses and their associations, says that Captain Price, of Plasyollin, with Captains Myddelton and Koet, on their return from the Azores in I59I, 'were the first who had smoked or (as they called it) drank tobacco publicly in London, and that the Londoners flocked from all parts to see them. Pipes were not then invented, so they used the twisted leaves, or segars. The invention is usually ascribed to Sir Walter Raleigh. It may be so, but he was too good a courtier to smoke in public, especially in the reign of James.' Again, in the I659 translation of Dr. Everard's Panacea (Antwerp, ${ }^{1} 5^{87}$ ), it is remarked that 'Captain Richard Grenfield and Sir Francis Drake were the first planters of it here (England), and not Sir Walter Raleigh, which is the common error; so difficult is it to fix popular discoveries.' These few selections show us how easily origins are lost sight of.

It seems ungracious to pluck a plume from one so eminently distinguished for important services rendered to his Queen and country as Sir Walter Raleigh; yet nothing in history is more certain than that the common belief crediting him with the first introduction of tobacco into this country is a myth. History, whilst awarding him the palm for potatoes, points to Sir John Hawkins as the first to bring to his countrymen the peaceful pleasures of the pipe. Certainly, the weight of probabilities are in his favour. Taylor, the Water Poet, says: 'Tobacco was first brought into England in 1565 , by Sir John Hawkins.' And Edmund Howes, in his continuation of Stow's Annals 
says : 'Tobacco was first brought and made known by Sir John Hawkins about the year 1565, but not used by Englishmen for many years after, though at this day it is commonly used by most men and many women.' These accounts correspond with Hawkins's second voyage, viz., October I8, 1564, returning September 20, $1_{5} 65$. Confirmatory evidence comes from John Sparkes, the younger, who, in his account of this voyage, says that Hawkins, ranging along the 'coast of Florida for fresh water, in July 1565, came upon the French settlement there under Landoniere, where the natives, when they travel, have a kind of herbe dryed, which with a cane and an earthen cup in the end, with fire and the dryed herbe put together, they do suck through the cane the smoke thereof, which smoke satisfieth their hunger, and therewith they live four or five days without meat or drink, and this all the Frenchmen used for the purpose.' Hearing these wonderful stories told of the Indian's herbe, nothing could be more natural than that Hawkins should make trial of it for himself, and, liking it, secure specimens of the plant for cultivation and use at home. To see and hear and get all he could, was the sole end and aim of his ploughing the Spanish main. Bearing in mind that he got back to England in September 1565 , we see that the statements of Taylor, the Water Poet, and Howes, the annalist, that tobacco was brought by Sir John Hawkins in 1565 , are consistent and reliable. Collateral evidence on the point is to be found in L'Obel's work on Botany, ${ }^{*}$ written in I570, wherein he says: "Within these few years the West

* Stirpium Adversaria Nova. Dedicated to Queen Elizabeth, by Mathias de L'Obel, Botanist, London, $157 \mathrm{I}$. Another edition was published at Antwerp in 1576. 
Indian tobacco-plant has become an inmate of England.' This of itself is conclusive against the Raleigh theory. But let us look a little further into the matter. In 1570 , Raleigh was a youth of eighteen, and had just gone to France to fight in the Huguenot cause. Again, in the State Archives, there is still extant an edict issued by Queen Elizabeth against the use and abuse of tobacco, dated r 584 - the year Raleigh's first expedition sailed to the New World.

It is amusing to find Queen Elizabeth fulminating against the pipe she afterwards so willingly countenanced in the mouth of her favourite knight. But then Sir Walter was in every way a splendid man, the typical gallant and hero in England's heroic age. Tall, dark, handsome, a noble brow, commanding voice and mien, he drew to his side willing hands ready to do his behest, be it what it might. A gay courtier, his dress was of the richest, and priceless gems sparkled on every finger. And so it came about that his proud Queen would quietly sit by his side, would playfully call him Walter, and listen to his tales of daring deeds and sufferings endured all for Good Queen Bess. And had he not won for her a new land full of rich promise, which, for her sake, was named Virginia? And thus they would talk on, Sir Walter smoking his finelywrought silver pipe in peace, forgetful of the fair, if frail, Maid of Honour, Bessy Throgmorton, listening, maybe, behind the arras. Alas! poor mortal man. The untoward affair at last broke upon Elizabeth like a thunderstorm in a serene sky, and our gallant hero became an outcast from the favour of his Queen.*

* The Queen could not brook the least defection of a courtier from absolute devotion to herself. 
Among the many anecdotes told of Raleigh's practices with his pipe may be mentioned that of his outwitting the Queen in a wager she laid with the gallant knight respecting the weight of the smoke which exhaled from a pipeful of tobacco. 'I can assure your Majesty,' said Raleigh, 'that I have so well experienced the nature of it that I can exactly tell even the weight of the smoke in any quantity I consume.' 'I doubt it much, Sir Walter,' replied Elizabeth, thinking only how impossible it must be to catch the smoke and put it in a balance, 'and will wager you twenty angels that you do not solve my doubt.' Whereupon Raleigh drew forth a quantity of the weed, placed it in finely adjusted scales, and having ascertained its weight, commenced to smoke it, carefully preserving the ashes. These at the finish he weighed with great exactness. Then would it dawn upon her Majesty how the wager was to end. 'Your Majesty,' said Raleigh, ' cannot deny that the difference hath evaporated in smoke.' 'Truly, I cannot,' was her reply. Then, turning to those around her, who were eying with amusement this curious play on the pipe, she continued, 'Many labourers in the fire have I heard of (alluding to alchemists) who turned their gold into smoke, but Sir Walter is the first who has turned smoke into gold.'

But the Indian weed had a hard fight to hold its ground in Europe and Asia in face of the most resolute opposition from potentates, statesmen, and priests. In England

The gentleman called King James

In quilted doublet and great trunk breeches,

Who held in abhorrence tobacco and witches, $f$

signalised himself and his reign by profound learning and ponderous invective hurled against the innocent plant,

f "The Witches' Frolic," Ingoldsby Legends, 
amongst whose alluring leaves there lurked the 'lively image and pattern of bell.' His Counterblaste to tobacco* is of itself an historic monument to his genius, which posterity does well to preserve that there may be something in hand to attest the just appreciation of his 'loving subjects ' in early recognising in him a Solomon! Though, to be sure, some will have it that the irreverent Henri Quatre was the first to see the fitness of the designation, Solomon, for the son of Mary, Queen of Scots. And yet his astute minister, the Duc de Sully, professed to have discovered in the flickering illuminations of this northern light 'the wisest fool in Christendom.' Historians who think it incumbent upon them to explain every human phenomenon or prodigy, have perplexed themselves with vain endeavours to unravel this curious compound of Machiavellian craft, fussy self-conceit and imbecility. Looking to his preternatural insight into the uncanny domain of the Black Arts, his mental conflicts with the de'il, witches and warlocks, and long nebbit things, the problem his character presents might perhaps form a fitting study for the modern school of psychology.

With the beginning of the seventeenth century commenced

* This work first appeared anonymously in 1604, and it is doubtful if an original copy is extant. Dr. Richard Garnett courteously informs the writer of these lines that there is not one in the British Museum. Professor Arber, however, has preserved a copy of it in his English Reprints. Arber says, 'How early its royal authorship was avowed I know not, but it was generally known long before its insertion in the collected edition of the King's works' in (1616).

Since the above was written Mr. Thomas Arnold, of HongKong, has informed the author that he possesses a copy-the only one extant-of the original edition, supplied to him by the late Mr. Bernard Quaritch, of Piccadilly. 
a literary warfare over the virtues and vices of St Nicotine, which lasted intermittently down to the present day. Mr. Solly, of St. Thomas's Hospital, in the middle of last century

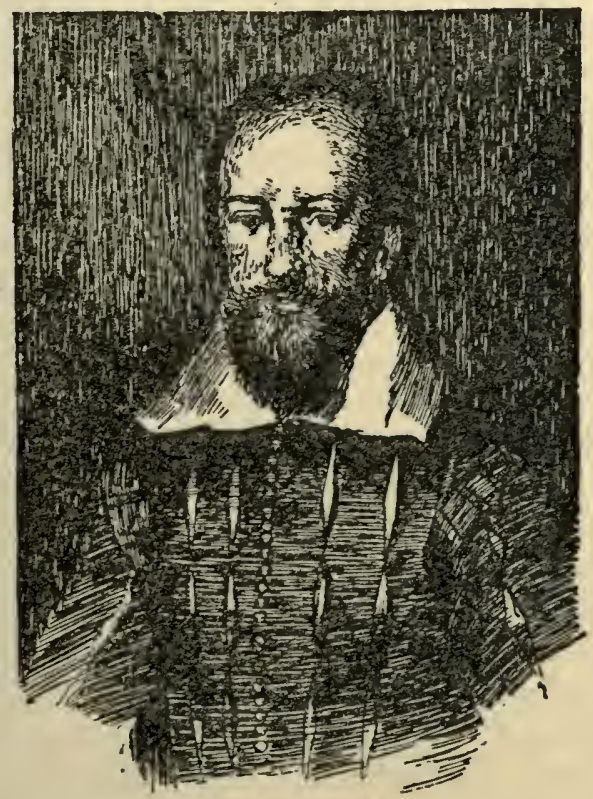

DUC DE SULLY

strove valiantly in the columns of the Lancet to get up a crusade against smoking. All the leading members of the medical profession took part in the affray; irrefragable statistics were piled up one upon the other as ramparts from behind which Mr. Solly proclaimed that there was death in the pipe; and the rapid degeneracy of the human race, to him everywhere apparent, was to be regarded as the inevitable consequence of indulgence in the pernicious weed. Had 
Mr. Solly referred to the text-book left by the royal founder of his faith, he would have learned the right use and value of trenchant utterance, and as a physiologist, would have gained knowledge never imparted in St. Thomas's Hospital.

The royal Counterblaste proclaims that 'smoke becomes a kitchen far better than a dining-chamber; and yet it makes a kitchen oftentimes in the inward parts of men, soyling and infecting with an unctuous and oyly kind of soote, as hath been found in some great tobacco takers, that after death were opened.' 'Have you not reason then to be ashamed and to forbear this filthie noveltie, so basely grounded, so foolishly received, and so grossly mistaken in the right use thereof? In your abuse thereof sinning against God, harming yourselves both in person and in goods, and raking also thereby the marks and notes of vanitie upon you; by the custom thereof making yourselves to be wondered at by all forraine civil nations, and all strangers that come among you, to be scorned and contemned.' King James clinches his argument with a logical acumen there is no resisting. 'Why,' he asks, ' since we imitate the beastly and slavish Indians in taking tobacco, do we not imitate them in walking naked? as they do'-an extraordinary idea to occur to one accustomed to wear dagger-proof quilted dress-'preferring glass beads and feathers to gold and precious stones? as they do; yea, why do we not deny God and adore the devil? as they do.' Then comes his famous climax: 'A custom loathsome to the eye, hateful to the nose, harmful to the orgain (brain), dangerous to the lungs, and in the black stinking fume thereof nearest resembling the horrible Stygian smoke of the pit that is bottomless.' If, after this display of royal indignation, stiff-necked ones still cast fond looks at the 'emblem of hell,' let them turn their attention to the King's words of wisdom stored up in a Col- 
lection of Witty Apothegms. Things that before were obscure to mental vision are here illuminated with a new radiance; it is made clear to us that 'tobacco was the lively image and pattern of hell, for that it had, by illusion, in it all the parts and vices of the world whereby hell may be gained-to wit, first: It is a smoke; so are the vanities of this world. Secondly: It delighteth them that take it; so do the pleasures of the world delight the men of the world. Thirdly: It maketh men drunken and light in the head; so do the vanities of the world, men are drunken wherewith. Fourthly: He that taketh tobacco saith he cannot leave it, it doth bereitch kim ! . . . And, further, besides all this, it is like hell in the very substance of it, for it is a stinking, loathsome thing, and so is hell.' But James had his moments of gaiety; he could jest over the arch enemy, and it would be most unfair to his memory to pass by any playful attempt at jocularity that for an instant flickered over his dreary brain. In the treasury of wisdom already mentioned, we are told that his Majesty once remarked that ' if he were to invite the devil to dinner he should have three dishes: 1. A pig ; 2. A pole of ling and mustard; and (3) a pipe of tobacco for digesture.'

There is a passage in the Counterblaste which seems to point directly to Raleigh; it runs as follows: 'Now the corrupt baseness of the use of this tobacco doeth very well agree with the foolish and groundless first entry thereof into this kingdom. It is not so long since the first entry of this abuse amongst us here, as this present age can very well remember both the first author and the form of the first introduction of it amongst us. It was neither brought in by king, great conqueror, nor learned doctor of physick. With the report of a great discovery for a conquest, some two or three savage men were brought in, together with this 
savage custom. But the pity is, the poor, wild, barbarous men died; but that vile, barbarous custom is yet alive, yea, in fresh vigour, so as it seems a miracle to me how a custom springing from so vile a ground, and brought in by a father so generally hated, should be welcomed on so slender a warrant.' The mention of 'two or three savage men' clearly indicates the return of Raleigh's first expedition in 1584, when Captain Amadas and Barlowe brought with them two American Indians, whose appearance in the streets was regarded as one of the sights of London. James's inveterate enmity towards Raleigh would seem to have originated at their first encounter at Burghly, in Lincolnshire, when the King faltered out: 'On my soul, mon, I hae heard but rawley o' thee,' a clumsy attempt at a pun. Doubtless Raleigh's noble bearing and rich attire would touch James's inordinate self-importance, which seems to have at all times blinded him to a proper sense of decency, according to Sir Anthony Weldon's simple, graphic presentation of him. On the King boasting that, had the English crown not been offered to him, his Scotch army would have taken it for him, Raleigh, indignant, made the injudicious remark: "Would God that had been put to the test.' 'Why ?' asked James. Raleigh recovering himself replied, "Your Majesty would then have known your friends from your foes.' ' Aubrey says that James never forgave this speech. One by one, Raleigh was stripped of all his offices; and before the end of the first year of James's reign (November $4, \mathrm{I}_{603}$ ) he was lodged in the Tower on a false charge of treason, and aiter fifteen years' imprisonment was judicially murdered by order of the King. Speaking of this event, Sir Anthony Weldom remarks, ' How this kingdom was gulled in the supposed treason of Sir Walter Rawley and others who suffered as traytors, 
whereas to this day it could never be knowne that there ever was such treason, but a mere trick of State to remove some blotches out of the way.' When Raleigh's fate drew nigh, 'he took a pipe of tobacco a little before he went to the scaffolde,' says Aubrey, 'which some female persons were scandalised at; but I think 'twas well and properly donne to settle his spirits.'

Speaking of this noble victim of James I., Sir Walter Besant, in his handsome volume on Westminster, says, 'Raleigh was brought to Old Palauce Yard to die. The day chosen for his execution was Lord Mayor's Day, so that the crowd should be drawn to the pageant rather than to his execution.' The body lies buried in the chancel of St. Margaret's Church, Westminster, where, near by, a tablet informs the visitor that

Within the walls of this church was deposited the body of the great Sir Walter Raleigh, Knt., on the day he was beheaded in Old Palace Yard, Westminster, 29 October, Ann. Dom. 1618.

Reader, should you reflect on his errors,

Remember his many virtues,

And that he was a mortal.

Considering the deep sympathy the nation has always evinced for the ill-fated yet illustrious knight, it is almost incredible that no monument has ever been erected to his memory. Raleigh was truly great in all those things which mankind loves to honour and perpetuate. In him patriotism, valour, and magnanimity stand out conspicuously in an age of heroes. Though endowed with a glowing, wildly-romantic imagination, he has left in his various writings evidence of extensive reading, keen insight, and sound judgment. The improvements he effected in naval architecture alone entitle him to the lasting gratitude of his country. The concluding lines of his History of 
the World written when the death sentence had been passed upon him and all his hopes of life had fled, are considered to be the finest and grandest example of prose in the English language. That Raleigh would not surrender his natural nobility of character to flatter the most abject monarch* that ever sat on the throne is to his everlasting honour, and marks him as a typical Englishman.

Through the medium of the notorious Star Chamber, the King, in I6I4, directed his efforts ostensibly to restrain the consumption of tobacco; in effect, to put an end to the infant colony of Virginia. For this purpose a bill was drawn up, addressed to 'Our Right Trustie and right well beloved Cousin and Counsellor, Thomas, Earle of Dorset, our High Treasurer of Englande, Greeting.' Then follows a rather perplexing, verbose preamble, the drift of which seems to be the hatching up of excuses for heaping upon tobacco a monstrous load of taxation for the avowed purpose of relieving 'many mean persons' of the heavy expense the habit of smoking entailed.

He tells his 'loving subjects' that smoking is an 'evil vanitie, whereby the health of a great number of people is impayered, and their bodies weakened and made unfit for labour, and the estates of many mean persons so decayed and consumed, as they are thereby driven to unthriftie shiftes onley to maintain their gluttonous exercise thereof.' After further admonition and warning of evils in store for the obdurate, the Act proceeds: 'We do therefore will

*It is difficult to speak of James $\mathrm{I}$. in measured terms. The reader is referred to Sir Anthony Weldon's Court and Character of King James (Smeeton's reprint, 1817). Raumer, ii. p. 200, says of James: 'He was a slave to vices which could not fail to make him an object of disgust.' Also, Winwood's Memorials. 
and command you, our Treasurer of Englande, and herebye also warrant and authorise you to give orders to all Customers, Comptrollers, Searchers, Surveyors and other officers of our Portes, that from and after the six-andtwentieth Day of October next comynge, they shall demand and take to our use, etc., etc., the sum of Sixe shillings and 8d. upon every pound weight thereof, over and above the custome of $2 \mathrm{~d}$. upon the pound weight usually paid heretofore.' The penalties for evading payment were, forfeiture of cargo, 'and such further Penalties and coporal punishments as the qualitie of suche so high a Contempt against Our Royal and Expresse Commandmente in this manner published shall deserve.'

The imposition, equivalent to about thirty shillings of our present money, had a startling effect on the tobacco trade of the country; but when merchants found out that it was meant to apply only to the tobacco imported from Virginia, they naturally had recourse to other markets, as Spain and Portugal, whence it was brought in at the old rate of twopence on the pound that had satisfied Elizabeth. Agriculturists, too, saw in the change an opportunity for extending the home cultivation and manufacture of tobacco, and readily availed themselves of it, particularly in Yorkshire, where all the operations connected therewith were well understood. On the King learning what they were doing, he hastened to promulgate a further edict forbidding husbandmen 'to misuse and misemploy the soyle of this fruitful kingdom,' beginning with the words, 'Whereas we, out of the dislike we have to tobacco.' Thus expressed, his case against the weed is placed in a more intelligible light than that which he had in the first instance thought it expedient to disclose. However absurd his reasoning, his policy succeeded only too well. Besides 
dealing a crushing blow to the young colony, his action had other far-reaching effects. It created a daring race of smugglers, who did a thriving contraband trade in tobacco with pirates on the Spanish main; and home dealers saw in the greatly enhanced price of the weed a temptation to 'sophisticate' too powerful to be resisted. Scattered through the literature of that period may be found some curious allusions to the practice, as in Ben Jonson's Alchemist, where Abel Drugger, speaking in praise of his tobacconist, says :

He lets me have good tobacco, and he does not

Sophisticate it with sack-lees or oil ;

Nor washes it in muscadel and grains,

* * * * * $\quad * \quad *$ *

But keeps it in fine lilly pots, that, opened,

Smell like a conserve of roses, or French beans.

He has his maple block, his silver tongs,

Winchester pipes, and fire of juniper.

In Bartholomew Faire he presents us with a picture of one, Ursula, a vendor of roast pig, bidding her servant 'Look to't, sirrah, you had best! three pence a pipe full I will ha' made of all my whole half pound of tobacco, and a quarter of a pound of coltsfoot, mixed with it too, to eke it out.' That sophisticating practices were growing apace may be gleaned from Dr. Barclay, of Edinburgh, who in his Nepenthes (1614) speaks of 'tobacco merchants apparelling European plants with Indian coats and enstalling them in shops as righteous and legitimate tobacco.' (How very conservative we English are!) 'Some others, indeed, have tobacco from Florida that they sophisticate and farde in sundrie sorts with black spice, galanga, aqua-vitæ, Spanish wine, anise seedes, oyle of spicke, and such like.' Less expensive materials than 
these were more commonly used (and perhaps still are), as the leaves of rhubarb, dock, burdock, plantain, oak and elm, also chickory and cabbage leaves steeped in tar-oil.

If the manufacturers of these and less innocent 'mixtures' really find themselves unable to withstand the pressure from without for a cheap smoke, let them confine their sophisticating ingenuity to simple vegetable products, such, for instance, as satisfied Dame Ursula. Coltsfoot or the leaves of the lettuce, being slightly narcotic, would form a harmless make-belief for the good folk who persuade themselves that they could not sleep a wink were they deprived of their evening comfort. Ages ago both Greeks and Romans, according to Dioscorides and Pliny, found comfort in smoking through a reed or pipe the dried leaves of coltsfoot, which relieved them of old coughs and difficult breathing. We can picture the legionary in Britain's bleak atmosphere, while pacing the Roman Wall, trying to console himself in his lonely vigil with the vapour from his 'elphin pipe,' fragments of which have been found among the ruins of those early memorials to the Scots' persistent determination to travel southwards. And as to the lettuce, it has been famous since the time of Galen (Claudius Galenus), who asserts that he found relief from sleeplessness by taking it at night. Regardless of these things, the Nicotian epicure of to-day enjoys the inestimable advantage of luxuriating in the delicate aroma of the Cuban leaf, while fancying himself wafted on his upward way to Nirvana. The charming simplicity that leads to this ideal conception of existence is most refreshing; the being so lost to the outer world can hardly be blamed if he says rude things when compelled to touch Mother Earth.

But King James had not yet done with tobacco. A monarch of his remarkable idiosyncrasy, as displayed in his 
creation of a new and lucrative business for the sale of distinguished titles and high offices of State, where he himself possessed the sole monopoly, would naturally see his way to a further stroke of 'good business' in the tobacco market. Accordingly, we are not surprised to learn that, viewing with a jealous eye the flourishing state of the new industry, the idea occurred to him that the State coffers might be replenished by taking a still deeper interest in the weed. Hence the issue of a royal proclamation to his loving subjects that they were forbidden to deal in tobacco unless they purchased Royal Letters Patent granting them a license to do so. These could only be procured, on payment of a yearly sum, from the persons who farmed from the King the right to enforce and collect the tax. In the Stafford Letters, compiled by Gerrard, relating to the collection of the new tax, it is stated that 'some towns have yielded twenty marks, $E_{\text {ro, }}$ $E_{5}, \mathcal{E}_{6}$, fine and rent; none goes under. I hear that Plymouth hath yielded $£$ roo and as much yearly rent. . - The tobacco licences go on apace; they yield a good fine, and a constant yearly rent. . . .' In some instances a life-lease to deal in tobacco was granted on payment of a lump sum. As to the King's method of dealing with State affairs of the kind, let Sir Anthony Weldon speak from personal knowledge. He says of the King that 'he was so crafty and cunning in petty things, as the circumventing any great man. He had a trick of cousen (cozen) himself with bargains under hand, by taking $\oint_{1}, \infty 00$ or $£ 10,000$ as a bribe, when (at the same time) his Counsel was treating with his Customers to raise them to so much more yearly; this went into his Privy purse; wherein he thought he had over-reached the Lords, but consented himself; but would as easily break the bargain upon the 
next offer, saying he was mistaken and deceived, and therefore no reason he should keep the bargain. This was often the case with the Farmers of the Customs.'

There is a document in the State Archives which throws a curious side-light on the King's ideas of statecraft. The settlers in Guiana had become tobacco-planters, and required a trade-charter with this country. A charter was granted them, in which a clause was inserted to the effect that one-tenth of the tobacco grown there should go to the King. Thus, in a roundabout way, the King became a tobacco merchant.

The concern which the King had professed for the 'many mean persons' of decayed fortune in debt for tobacco had not resulted in helping them out of their difficulties, but rather the contrary. From Aubrey we learn that its cost had risen to the value of silver. $\mathrm{He}$ says, "I have heard some of our old yeomen neighbours say that when they went to Malmesbury or Chippenham market they culled out their biggest shillings to lay in the scales against the tobacco. Now (I680) the Customes of it are the greatest his majestie hath.' In various documents of the period, tobacco is mentioned amongst the most expensiye luxuries. Even in Elizabeth's reign its price ranged from Ios. to I8s. a pound, according to the quality.

Meanwhile, jovial spirits were amusing themselves with a lively paper warfare over the virtues and vices of the rare Indian plant that, according to the King, had bewitched them. Early in the fray (1602), appeared anonymously a booklet entitled, Work for Chimmey Sweepers, or a Warning to Tobacconists, calling the smoker's attention to the necessity for securing the services of one of those useful members of the community. At that time it was 
the fashion among gallants of the weed to draw the smoke into the lungs and to eject it 'through the organs of the nose, with a relish that inviteth,' says the gay, laughing, Doctor Barton Holiday, who took such a wicked delight in tormenting King James at Woodstock in his play of the Marriage of the Arts. This was speedily answered by A Defence of Tobacco, printed by Richard Field for Thomas Man, wherein the author shows that the 'warning' should have roosted at home, where, in its absence, zeal had outrun discretion, and had thereby damaged the cause it would fain have served.

Verbose titles, full of alliteration, fire and fun, were much appreciated by the militant writers of this period. Witness the following heading to a poem against tobacco by Joshua Sylvester, Gent., the favourite poet of King James: 'Tobacco battered, and the pipes shattered (about their eares that idely idolize so base and barbarous a weed; or leastwise over-love so loathsome a vanitie), by a volley of Holy shot, thundered from Mount Helicon.' After this brave warning we are prepared to hear that

Hell hath smoake

Impenitent tobacconist to choake.

Though never dead, there shall they have their fill;

In heaven is none, but light and glory still.

Samuel Rowlands in his Knave of Clubbs (I6II) writes in a lighter strain, and asks :-

Who durst dispraise tobacco whilst the smoke is in my nose, Or say, but fah ! my pipe doth smell! I would I know but those Durst offer such indignity to that which I prefer;

For all the brood of blackamoors will swear I do not err, In taking this same worthy whiff with valiant cavalier, But that will make his nostrils smoke, at cupps of wine or beer, 
When as my purse can not afford my stomach flesh or fish, I sup with smoke, and feel as well and fat as one can wish. * * * * * * * * * * * * Much victuals serve for gluttony, to fatten men like swine, But he's a frugal man indeed that with a leaf can dine, And needs no napkins for his hands his fingers' ends to wipe, But keeps his kitchen in a box, and roast meat in a pipe. This is the way to help down years, a meal a day's enough ; Take out tobacco for the rest by pipe, or else in snuff, And you shall find it physical; a corpulent, fat man, Within a year shall shrink so small that round his waist you'll span.

It's full of physic's rare effects, it worketh sundry ways : The leaf green, dried, steep't, burnt to dust, have each their several praise.

While Englishmen smoked, and laughed at their King's wondrous ways, or growled at his tenacious grip upon their pockets, Eastern potentates were treating their subjects, as only despots can, for daring to indulge in the Frankish novelty. In Persia, where but recently jealous strife raged for sole possession of the tobacco industry, Abbas I., of dread memory, cut off the lips of those who smoked, and the noses of any who ventured to snuff. On one occasion he threw an unfortunate man, whom he discovered selling tobacco, into a fire along with his goods. Yet, by-and-by, this demon of cruelty himself was enthralled by Nicotiana's charms, and became one of her most fervent devotees. The Turks, under Amurath IV., were similarly punished for infringing his edict against smoking. Sir Edwin Sandys, of Pontefract, in his travels in 16 Io, bears testimony to similar acts of cruelty by Mahomet IV. During his stay in Constantinople he witnessed the punishment of a Turk who had been caught solacing the burden of life with the vapour of his new-found joy. Short-lived was the sturdy 
beggar's happiness; he was dragged before the tribunal, and condemned to the torture of having a hole pierced through the cartilage of his nose, and a pipe inserted therein. Then, in order to render the punishment more impressive to the multitude, he was seated on the back of an ass with his face to the tail, and driven through the streets of the city, while criers proclaimed his offence and its merited punishment, according to the law of the Sultan. Not less cruel were the punishments inflicted upon Russian smokers, who, under the Tsar Michael Fedorowitz, were publicly knouted for using tobacco in any form; in some instances their nostrils were split open. If guilty of a second offence, death alone could wipe out the crime. The ambassadors of the Duke of Holstein, who visited Moscow in 1634 , relate that they were eye-witnesses of a public exhibition of this kind, where eight men and one woman were punished with the knout for selling tobacco. By way of palliating this Russian atrocity, they were informed that houses in Moscow had been set on fire by smokers falling asleep and dropping their lighted pipes.

Oppression, however, like persecution in another sphere, brought succour to the smoker; for, despite every form of opposition and punishment, men quietly went on comforting themselves with the weed, until at last their bitterest foes became their best friends, and gratefully acknowledged the benigh sway of St Nicotine.

There is a peculiar interest, not without instruction, in observing the change that came over governments with regard to the consumption of tobacco. One after another they began to recognise a new and most useful virtue in the outcast weed, one which had too long remained hidden. Straightway they took the exotic under their paternal protection, and handsomely were they rewarded for their acknow- 
ledgment of her value to mankind. By-and-by, many an anxious custodian of an empty treasury came to look upon St Nicotine as a divinity

\section{- . . that cures, a vapour that affords}

Content more solid than the smile of lords,

and as they gathered in their golden harvest of taxation, blessed the name of their benefactress.

In illustration of this change may be mentioned the action which Peter the Great took with the view of establishing tobacco culture and manufacture in his dominions. In the tenth volume of M. de Martin's magnificent work on the treaties and conventions concluded by Russia with other nations from I 7 Io to I80I, there is a paragraph which states that Peter the Great, having determined that tobacco should be cultivated and manufactured in Russia, sought in England the necessary workmen, machinery, implements, etc., for transmission to Moscow. Englishmen knew little at that time of the remote Tsardom of Muscovy, but on learning the wants and wealth of the monarchy, enterprising merchants were not slow to undertake the performance of all that was required of them. Accordingly, a party of skilled workmen, with engineers, was soon on its way to Moscow with all necessary material for setting up and working a tobacco factory. When, later, the English Government was apprised of what had been done, 'Her Majesty, Queen Anne, in Council, was pleased to manifest her profound dissatisfaction, especially in that they proceeded to the realm of Moscow to the cultivation of the native products of her Majesty's dominions, and in that they have brought to Moscow for this purpose the requisite English workmen and material, which is contrary to the interests and usages of the kingd om of Great Britain.' Orders were immediately sent 
to our envoy at Moscow to not only return the workmen to their homes, but to privately and secretly destroy all the materials, machines and instruments of production.

It is not a little amusing to learn how energetically the envoy carried out the order of destruction. He relates at considerable length in his home despatch how he and his secretary (a private secretary undoubtedly) spent a night in breaking up all the machinery and laying waste the material; how he afterwards explained to the Tsar that the object of his zealous operations in smashing up the plant was to save his Majesty's subjects from a burdensome monopoly and thus, really, to encourage and enhance the tobacco trade in Russia. Remembering that the Tsar was Peter the Great, we are not surprised to learn that our excellent envoy was listened to with impatience. 


\section{CHAPTER IX.}

SOCIAL GOSSIP ABOUT THE WEED.

Why should we so much despise So good and wholesome an exercise As early and late, to meditate?

Thus think, and drink tobacco.

G. W.

Ancifnt and delightful George Wither, while suffering for conscience' sake imprisonment in the Marshalsea, found a never-failing comfort in his beloved Indian weed. Its soothing vapours moved him to meditation; the earthen pipe, the burning weed, the vanishing fumes, and the ashes left behind, were to him emblems of the transitory nature of man's earthly career. Musing thus, he poured forth his thoughts in a poem which has taken a firmer hold on the popular taste than any other of the countless songs composed on the subject of tobacco. It has undergone numerous alterations, but in every instance for the worse. In a mutilated form, and with a second part added, it is found among the 'Gospel Sonnets' of the Rev. Ralph Erskine, of the Scottish Church. It is the 'Smoking Spiritualized ' which is still in print among the ballad-vendors of the east end of London. It reappeared with variations in Mr. J. H. Dixon's 'Songs and Ballads of the Peasantry of England'; and again in the Rev. James Plumptre's 'Tobacco is an Indian weed.' So popular had 
the song become that Dr. Hague, in 1805 , set the words to music, and Mr. Samuel Wesley, at a later date, adapted them to a tune said to be still in vogue. Yet, out of the multitude of admirers who so readily adopted and adapted Wither's song, no one seems to have cared to acknowledge the source of his inspiration. But for the diligent reseach of Mr. Payne Collier, the student might have remained forever in ignorance of its true parentage. Turning to Mr. Chappell's 'Popular Music of the Olden Time' we come upon the following passage relating to this song:- 'The earliest copy' says Mr. Chappell, ' $I$ have seen is in a manuscript volume of poetry transcribed during James's reign and which was kindly lent to me by Mr. Payne Collier. It there bears the initials of $\mathrm{G}$ [eorge] W[ither] a very likely person to have written such a song. A courtier poet would not have sung the praises of smoking-so obnoxious to the King as to induce him to write a Counterblaste to Tobacco-but Wither despised the 'servility which would have tended to his advancement at Court. The original song, the first verse of which is at the head of this chapter, runs as follows :-

The earthen pipe so lily white

Shows that thou art a mortal wight ;

Even such - and gone with a small touch :

Thus think, and drink tobacco.

And when the smoke ascends on high, Think on the worldly vanity Of worldly stuff-'tis gone with a puff;

Thus think, and drink tobacco.

And when the pipe is foul within Think how the soul's defiled with sinTo purge with fire it doth require :

Thus think, and drink tobacco. 
Lastly, the ashes left behind

May daily shew to move the mind,

That to ashes and dust return we must :

Thus think, and drink tobacco.

As a soother of sorrow in wedded life, the story told by Camden of good Richard Fletcher, Bishop of London, shews how over-indulgence in the weed may carry its votary farther than he wots of. For his sins, people would say, the Bishop had to endure the plague of a scolding wife. The burden became greater than he could bear; he sighed for the peace that failed him, and in his distress he fell to smoking so immoderately that at last his weary spirit took flight on the wings of the weed to the realms of rest he longed for. There is a pathos in the story that awakens a kindred feeling; one can see the peace-loving prelate quietly slipping away from the domestic storm, and, finding sanctuary in his attic, yielding himself a willing martyr to the solace of St Nicotine. Indeed, if the truth must be told, the clergy, ever since her advent in these islands, have been noted votaries at her shrine. Instances crowd upon us.

A curious example is found in the pages of the astrologer Lilly's Memoires published in I 7 I5, thirty-four years after his death. We are told of one, William Bredon, vicar of Thornton, in Buckinghamshire, who was so far given over to the taking of tobacco in a pipe that when his supply was run out he would cut off the ends of the bell-ropes and smoke the bits. But this unworthy lover of his pipe was profoundly learned in Eastern lore, particularly that which related to judicial astrology. It may well be, that, along with his learning, he derived from the same source his knowledge of hashish. The practice of inhaling the fumes of burning hemp, was, as we have already seen, common in the near East, before tobacco had reached the Moslem. 
It is next to impossible to dip into the pages of the early playwrights and pamphleteers without coming upon mirthful allusions to the new indulgence. Ben Jonson, Thomas Dekker, Samuel Rowlands, and a host of other writers in those jubilant days, found in the weed and the habits of smokers a never-failing source for good-natured raillery.

In Every Man out of his Humour we learn that the rage for tobacco had spread to the provinces. One, Sogliardo, is described as essentially a clown, yet so enamoured of the name of gentleman that he will have it though he buys it. He comes to town every term to learn the manners of polite society, and readily falls a victim to men of the Bobadil type, who sees in the novelty a new field of enterprise. Jonson describes their methods, and speaks of a bill posted in St. Paul's churchyard notifying fledglings from the country that instruction in the art of taking tobacco can be arranged for. It affords us a glimpse of the smart men-about-town three centuries ago who lay in wait for inexperienced youth. It runs as follows :-

'If this city, or the suburbs of the same, do afford any young gentleman of the first, second, or third head, more or less, whose friends are but lately deceased, and whose lands are but new come into his hands, that, to be as exactly qualified as the best of our ordinary gallants are, is affected to entertain the most gentleman-like use of tobacco; as first to give it the most exquisite perfume, then to know all the delicate sweet forms for the assumption of it, as also the rare corollary and the practice of the Cuban ebolition, Euripus, and Whiffe, which he shall receive or take in here at 
London, and evaporate at Uxbridge, or farther, if it pleases him. If there be any such generous spirit that is truly enamoured of these good faculties, may it please him but by a note of his hand, to specify the place or ordinary where he uses to eat and lie, and most sweet attendance with tobacco and pipes of the best sort shall be ministered. Stet, quaso, candide lector.

After King James had sent forth his famous Counterblaste in 1604 , declaring to the world that tobacco was the 'lively image and pattern of hell,' it was not unusual to hear the weed associated with the arch enemy. And rare Ben would seem to have been nothing loth to trim his sails to the new breeze. In his masque entitled The Gipsies Metamorphosed he is so considerate as to wish that his Majesty's nose may be protected from the smell of

Tobacco with the type Of the Devil's glyster pipe.

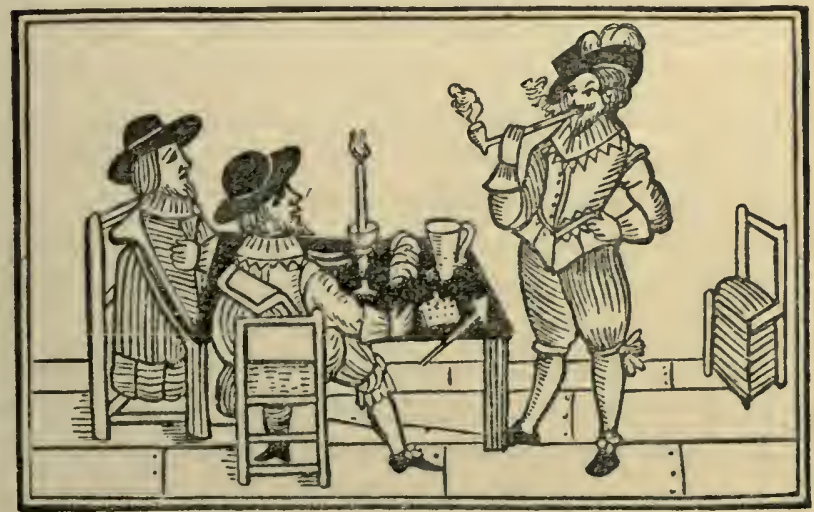

EARLY SEVENTEENTH-CENTURY SMOKERS 
The play accorded so well with the King's humour that he commanded a repetition of the performance. At that time tobacco-smoking was commonly indulged in at theatres. In Bartholomew Fair a pleasure seeker, named Coke, enters a puppet show and asks of the master, ' $\mathrm{Ha}$ ' you none of your pretty impudent boys, now, to bring stools, fill tobacco, fetch ale, and beg money, as they have at other houses?'

We pass on to the pages of Thomas Dekker-Dekker the gay, the light-hearted, and always good-humoured, who says of himself that, 'the imagination runs to and fro, the fantasie flies round about, the vital spirits walk up and down, yea, the very pulses shew activities, and with their hammers are still beating, so that in my very dreams it is whispered in my ears that I must be up and doing something.' Among his many delightful sketches of social life in London, the Gulls Hornbook may well rank first. He makes sport of the young gallants of the city who affect the fashionable habit of 'taking tobacco,' and instructs them how to handle, in the most approved style, the implements with which they are to be provided. In the same bantering tone he apostrophises tobacco thus: 'Make me thine adopted heir, that, inheriting the virtues of thy whiffs, I may distribute them among all nations, and make the fantastic Englishman above all the rest more cunning in the distinction of thy roll-Trinidado, leaf and pudding, than the whitest toothed blackamore in all Asia.'

In one of those unaccountable freaks of temper which at times seem to take possession of genius Jonson, in the The Poetaster made an unprovoked attack upon Dekker, who, in no way daunted, flew to arms, and in his Satiromastix or the Untrussing of the Humerous Poet, 
proved himself to be no unworthy match for his more ponderous assailant. In this masterpiece of Dekker's we come upon the earliest allusion to women smokers. Asinius Babo meeting with friends proffers his pipe saying, "tis at your service, gallants, and the tobacco too; 'tis right good pudding I can tell you: a lady or two took a pipeful or two at my hands and praised it 'fore the heavens.' We learn from Aubrey that in his day (I680) it was considered very improper for 'feamale persons' to take tobacco. But women's curiosity respecting the new allurement to indolence with which men were so greatly enamoured very naturally led them to taste the forbidden leaf. Bearing on this point is a piquant story told by Miss Pardoe in her admirable History of the Court of Louis XIV. The Grand Monarque had a great aversion to tobacco, and no one ventured to smoke in his presence. But his daughters had noticed how comfortable and cosy the men of the Swiss Guard looked while smoking their pipes, and longed for a more intimate acquaintance with the novelty. They grew weary of the restraints of the court circle and sought freedom in their own apartments. On one occasion, when the Dauphin had at a late hour quitted the card-table, he heard noises of revelry while passing their quarter of the Palace. Entering to ascertain the cause, he was astonished to find the princesses engaged in smoking. Their pipes had been borrowed from the officers, who doubtless were instructing them how to make clouds, rings and squirts. Miss Pardoe speaks strongly; she says that when the princesses became weary of the 'gravity and etiquette of the court circle they were accustomed to celebrate a species of orgie in their own apartments, after supper.' But after all were they not Eve's daughterswhat else could be expected? 
In England the paper warfare over the merit or demerit of the 'Indian's weed,' signalized by King James, lasted well through two centuries. Beginning with some slight skirmishing, as in Work for Chiuney Sweepers we come to a doughty champion of the royal cause in the person of 'Josuah Sylvester, Gent:' he who with quixotic valour sent forth a 'Volley of Holy Shot Thundered from Mount Helicon.' In dedicatory lines addressed to George, Duke of Buckingham, he invokes the aid of the royal favourite to enable him to overthrow the

Of th' Infidel, usurping faith's possession,

That Indian tyrant, England's only shame

Thousands of ours he here hath captive taken,

Of all degrees kept under slavish yoke

Their God, their good, King, country, friends, forsaken,

To follow follie, and to feed on smoke.

Scanning the horizon he discovers Satan, enraged, working in short circuit two smoky engines-'guns and tobocco pipes vented from the infernal pit.' In this turgid style he pours out his puerile conceits much in the manner of his royal patron, whose good opinion he won so fully that James made him his Court poet.

The levy of a duty on tobacco so excessive as that which King James imposed namely, six shillings and tenpenceequivalent to about thirty shillings of our present moneyupon every pound weight imported or grown in the country, coupled with great extravagance in its use brought ruin to many families, just as does over-indulgence in strong drink to those who are not satisfied with the moderation which reason dictates. In the case of tobacco the ruin was in money, whereas with alcohol in excess ruin comes to body and mind as well as purse. Our excellent guide along the 
by-paths of literature, John Aubrey, from whom we have gleaned many things respecting the use of tobacco, says, 'In my early days (temp. Charles the First) tobacco was sold for its weight in silver.' And in the family account-books of well-to-do people that have come to light we get occasional glimpses of its cost. A book of household expenses kept by Sir Henry Oglander, of Nunwell, in the Isle of Wight (1626), contains an entry of five shillings paid for eight ounces of tobacco. The price varies on different dates, according to the quality of the weed. Virginian seems to have been the favourite growth, though Spanish is the more frequently mentioned. A worthy old gentleman named Peter Campbell, living in Derbyshire, was so incensed against the smoking habit that in his Will, making over his household goods to his eldest son, Roger, he inserted a special clause to the effect that if at any time either his brothers or his sisters 'fynd him smoking of tobacco he shall forfeit all or their full valew.' Roger, who loved his pipe, would be lucky indeed if he escaped the watchful eyes of his five brothers and three sisters.

Sir Edwin Sandys, Member of Parliament for Pontefract, (I620) grew alarmed at the prodigious quantity of tobacco consumed in this country, and inquiring into the matter found that Spain was sending to England tobacco to the value of $E_{100,000}$ a year for which in payment 'we sent our cloths and other merchandise. . . Nay, that sum will not pay for all the tobacco we have from thence; they have more from us every year: $£^{20,000}$. So that there goes out of this kingdom as good as $£$ r20,000 for tobacco every year!' He would have opened wide his eyes with amazement if some genius had whispered in his ear that under Edward VII. the duty alone on the quantity consumed in these islands would amount to over 
$£ 13,000,000$ a year. The increased and constantly increasing consumption of tobacco, prodigious as it was in the eyes of our forefathers, was not peculiar to England. Dr. Everard in his treatise on the Wonderful Virtues of Tobacco taken in a Pipe * says that its use had spread with amazing rapidity all over the known world, and that its cultivation and manufacture gave employment to millions of people who, were the consumption stopped, would probably perish for want of food. He likens the rise and progress of the industry to Elias's cloud, 'which was no bigger than a man's hand . . . It hath suddenly covered the face of the Earth: the low countries, Germany, Poland, Arabia, Persia, Turkey; almost all countries drive a trade in it, and there is no commodity that hath advanced so many small fortunes to gain great estates in the world.' The translator adds, 'Scholars take it much, and many grave and great men take tobacco to make them more serviceable in their callings. . . Soldiers and seamen cannot but want it during their arduous duties in cold and tempestuous weather. Farmers, ploughmen, porters, labourers, plead for it, saying, they find great refreshment by it.'

English smokers cared little for the fulminations against the indulgence issued from high places. Even a taxation which in these days would provoke a riot merely drew from them a mild growl. An example of this more excellent way is found in Dr. Barclay's Nepenthes, or the Vertues of Tobacco. In the tranquil spirit of a devotee of St Nicotine he addresses to 'My Lord Bishop Murray' the following lines:

* Published at Antwerp, 1659, and translated by I.R. Dedicated to the Merchants and Planters of Tobacco. 
The statelie, rich, late conquer'd Indian plaines,

Foster a plant, the princess of all plants,

Which Portugall, after peril and paines,

To Europe brought, as it most justly vaunts ;

This plant at home the people and priests assure,

Of his goodwill, whom they as God adore ;

Both here and there it worketh wonderous cure,

And hath much heavenlie vertue hid in store.

A stranger plant shipwrecked on our coast,

Is come to help this colde phlegmatic soyle,

Yet cannot live for calumnie and boast,

In danger daylie of some greater broyle.

My Lord, this sacred herbe which never offendit,

Is forced to crave your favour to defend it.

The author's exalted idea about the great value of the weed was a reflex of the Indian's belief in its all-healing properties, a notion which through the Spaniards and Portuguese had become the common property of Europe. This is the animating thought running through the work. $\mathrm{He}$ has set his heart upon curing suffering humanity of every malady, and he complacently likens himself to Hercules going out into the world to wage war on disease and corruption. 'I have armed myself with a box for his bag,' says the learned doctor, 'and a pipe for his club; a box to conserve my tobacco, and a pipe to use it.' $\mathrm{He}$ foresees a time coming when the medicinal virtues of the herb will be so well understood that the services of physicians may be dispensed with, particularly in cases of defluxion and catarrh. Warming to his work and holding up the native home of the plant to be a 'Country which God hath honoured and blessed with this holy herbe,' he flourishes his club defiantly in the face of 'the unlearned leiches' who dare to say evil things about Nicotiana; 'God willing,' he means to 'overcome many maladies.' In 
practical work, however, thoughequally earnest, he is a long way behind his contemporary, Dr. Gardiner, whose Trial of Tobacco has already been noticed.

By the middle of the seventeenth century, tobaccosmoking had become a confirmed habit even in remote rural districts, and was duly recognised and provided for by every housewife. Monsieur Jorevin de Rochefort in his travels in England ( 1672 ) tells a homely story of his sitting down to supper with a friend in Worcester, where, on the meal being finished, they set on the table half a dozen pipes and a packet of tobacco for smoking. On inquiry he was told that it was a common practice to smoke after supper, indulged in by both men and women, who said that without tobacco one cannot live in England, for the smoke dissipates the evil humours of the brain. He goes on to relate his further experience on the next day, saying :

'Whilst we were walking about the town he asked me if it was the custom in France, as in England, for children on setting out for school to carry in their satchel along with their books a pipe of tobacco, which their mother had taken care to fill early in the morning, in the belief that it would serve them instead of breakfast.' Surely our French friend was grossly imposed upon. No English mother would for a moment entertain such a notion. We are next told that at the accustomed hour every one laid aside his book to light his pipe; and that the master smoked with them and taught the youngsters how to hold their pipes and draw in the tobacco-smoke; thus using them to the habit from youth, believing it absolutely necessary for health's sake. The story told him by his Worcester friend put him in mind of a Spaniard whom he had met at the seaport of Calabria. The man, not being able to procure tobacco, cut 
off a piece of the cable with which he filled his pipe and drew down the smoke thereof as if it were the precious weed. $\mathrm{He}$ speaks, also, of an Irishman who falling ill was not allowed his usual pipe of tobacco. He submitted for some time, but he became so low and so melancholy that he could take nothing but a little tobacco, which was at last permitted him, with the result that in a short time he recovered perfect health. 'I have known,' says Rochefort, 'several persons who, not content with smoking in the day, went to bed with their pipes in their mouths. Others who have risen in the night to take tobacco with as much pleasure as they would have received in drinking Alicant or Greek wine.' Profligate smokers such as these deserve no encouragement or sympathy; they rank in the class of the besotted.

Rarely do we meet with more sympathetic words in favour of the weed than in Mission's Memoies of Travels over Eugland, which he published in 1697. Tobaccosmoking, he says, was commonly practised both by men and women, particularly in country places. His observations led him to remark that smoking makes the generality of Englishmen taciturn, thoughtful, and, alas, melancholy; he adds that the use of tobacco 'not only breeds profound theologists, but also begets moral philosophers.' And in a sonnet, which bears some resemblance to the verses of George Wither, he shows us that he had himself imbibed something of the melancholy and philosophic spirit he speaks of. The lines run as follows :

Sweet smoking pipe ; bright glowing stove,

Companion still of my retreat,

Thou dost my gloomy thoughts remove,

And purge my brain with gentle heat. 
Tobacco, charmer of my mind,

When like the meteor's transient gleain,

Thy substance gone to air, I find,

I think, alas, my life's the same !

What else than lighted dust am I ?

Thou show'st me what my fate will be ;

And when thy sinking ashes die,

I learn that I must end like thee.

A more robust, nay, hilarious, spirit pervades the utterances of Dr. Henry Aldrich, Dean of Christchurch, Oxford, who in devotion to the weed surpassed even Dr. Parr of cloud-compelling fame. The genial don had found in the pipe a solace for his somewhat fretful temperament; it disposed him to look upon life with the benevolent composure of a mind at peace with the world. Indeed, the love he bore his pipe, says his biographer, Sir John Hawkins, was so excessive as to be an entertaining topic of discourse in the University. The belief that the Dean and his pipe were inseparable, led to wagers being laid on the chance of finding him without it. With the keen wits for fun and mischief, characteristic of schoolboys, students would now and then warily peer into his sanctum at early morn or dewy eve, in the hope of settling the disputed point. On one occasion the doctor, learning the object of their visit at an early hour in the morning, readily fell in with their humour, and declared to the foremost boy, that, 'Your friend has lost. I am not smoking, only filling my pipe.' The Dean's geniality comes out well in his humorous 'Catch on Tobacco,' which appeared in his second book of The Pleasant Musical Companion, published in 1687 . He tells us that it is 'to be sung by four men at the time of smoking their pipes.' The first verse is as follows:- 
Good! good, indeed!

The herb's good weed ;

Fill thy pipe, Will, and I prithee, Sam, fill, For sure we may smoke and yet sing still;

For what say the learned? Vita fumus,

'Tis what you and I, and he and I, and all of us sumus.

If the so-called 'Smoking Concerts' of to-day were carried out in strict accordance with the founder's instructions, each being supplied with the legitimate materials, the public would then get the amusement implied in the designation, 'Smoking Concert.'

Before taking leave of the amiable Dean, it is but just to his memory to say a word on his higher claims to admiration. It is recorded of him that he distinguished himself in every branch of divine and human learning; that he promoted religion and virtue with application and zeal during his tenure of office at the noble college of Christchurch, much of whose present lustre and beauty it owes to his efforts. His biographer ranks him among the greatest masters in the composition of church music; his anthems number about twenty. Yet, being a man of genial humour, he found diversion for his leisure moments in the production of pieces of a lighter description, as, 'Hark! the bonny Christchurch Bells,' which at one time had a great vogue. 


\section{CHAPTER X.}

THE TOBACCO INDUSTRY AND SMOKING PIPES.

THE various kinds of tobacco and the sources of supply are exceedingly numerous. Every country, indeed, has attempted to cultivate the plant and reap a share of the rich harvest it yields to the planter and to the government. Special qualities, as of wine, belong to particular localities, outside of which they cannot, by any skill or coaxing, be raised. A puzzling example of nature's fickle moods in the production of the plant was found a few years ago in Sumatra, where on one side of a field a leaf was yielded rich in all the qualities delicate smokers desire, and on the other side, but a few yards off, a very inferior plant grew. So far as an experienced cultivator could see the conditions were alike: seed, soil, and culture and aspect were the same. And as is the case with wines, the crops vary in richness and delicacy of flavour with the seasons of their growth, so that in some years the yield is of much greater value than in other years, though tobacco of the 'Comet year' has not yet been proclaimed in commerce. The natural properties of certain classes of tobacco render them especially suited for cigar-making; others are best fitted for smoking in pipes, and there are numerous qualities which are valuable for snuff-making. National tastes and habits again frequently determine the destination of the 
weed. Thus, heavy, full-flavoured cigars and strong pipetobacco are in favour in North America, while in Europe, lighter, and more brisk-burning are sought after. By far the most valuable tobaccos in the world are grown in Cuba, and the richest of all is found in the gardens of Vuelta Abajo in the north-west district; after which come the products of Partidas and Vuelta Arriba. A large portion of the tobacco is made into cigars in the island, but considerable quantities are exported to Europe for mixing with commoner kinds to give Havana flavour to homemade cigars. Cuba, though no longer the emporium of the tobacco world, still ranks first among the favoured places of the earth for the finest growths of the plant. In culture and make-up, in classification and nomenclature of the different kinds of tobacco, the Queen of the Antilles is, as she has always been, a model to the tobacco-producing world. Foremost among her thousand factories stands the Royal and Imperial of La Hondradez. It occupies a whole square, and is looked upon as one of the sights of Havana. Before the McKinley tariff cast gloom over the Home industry, this factory, alone, produced nearly two millions of cigarettes daily; and the total number of cigars exported in 1889 was about two hundred and fifty millions. Under the McKinley tariff the exportation of cigars declined rapidly to about one half this number, with the consequent loss of employment for factory operatives. On the other hand, however, the exports of unmanufactured leaf rose in like proportion. The highest class of Cuban cigars called 'Vegueras,' are prepared from the finest growths of the plant raised in Vuelta Abajo. Here, the plant growing in its native soil attains its richest perfection. The soil is a light sandy loam, very rich in potash and lime, and as the heat and humidity are great it is an ideal site for the 
tobacco plant. In the preparation this valuable leaf is never damped with water, as is done with the inferior kinds, but when it is just half dry it is rolled, and thus the full, natural and most delicately flavoured qualities are retained. Next come the 'Regalias' which are treated in a similar way; but genuine Havanas are seldom to be had in Europe. The area in which these plants are grown is so small that it is physically impossible all the cigars sold under these names can be real Havana 'legitimas'; and the price they command places them beyond the reach of ordinary smokers. So it happens that the cigars made in Europe from any Cuban tobacco are usually classed as 'Havanas.'

Of the many different methods of harvesting and preparing the leaves of the plant for commerce, one of the best is said to be that recently adopted in Florida. The latest results would seem to justify the sanguine hopes of the planters that by-and-by they will produce a tobacco in all essential particulars equal to Havanas. They trust mainly to a new method of reaping. Instead of waiting, as in the old way, until the whole field is ripe, they keep a close watch on the crop, and as each leaf becomes ripe, which a skilled eye readily detects, it is taken from the stalk and placed with other fully ripened ones in a broadbottomed basket, or tray, and carried to the curing-house. Here the leaves are sorted and sized, strung and hung up in rows and tiers, and when all the field has been gathered leaf by leaf, and the other operations completed, the steaming apparatus is brought into action-hot-water pipes leading to evaporating pans-and the proper degree of heat secured to produce the desired fermentation. By dint of care in the regulation of the heating apparatus, so as to secure the proper temperature in the curing rooms, and in 
the collection of the leaves undergoing the process of curing at the proper moment, the delicate aroma considered to be peculiar to the best Cuban growths is secured in greater perfection than could be attained under the old method of leaving the gathering until the whole field had ripened. It is reported from the district that the longer time expended in the somewhat tedious operation of collecting each leaf separately as it becomes ripe, is more than compensated by the lessened labour of indoor work. Then there is the superior texture, colour, weight and richness over those which the old plan yielded. There still remains, however, for consideration, the all-important factors of soil and climate, and whatever else in nature may go towards determining the ultimate fate of the plant. It is thought that all the favouring conditions are in Florida harmonized more perfectly than in any other part of the United States.

Housing and curing operations completed, the leaves being quite dry and crisp, they are loosely tied in bundles (a leaf being used for the purpose) of about a dozen, called 'hands,' and lightly packed together for the Home market. The tobacco intended for exportation receives much morecare in the packing. Each bundle is placed carefully in a hogshead or other large receptacle in such a manner as not to injure the leaf in any way. In some cases the midrib-the fibre which runs through the leaf-is removed before exportation, an operation which has given rise in commerce to the designation 'stripes,' a term by which large quantities of tobacco is known in the market. When a hogshead is about one quarter filled a powerful lever-press is employed to compress and consolidate the tobacco. This pressing is repeated at each successive stage of the packing till the whole is a dense and compact mass, weighing from a thousand to twelve hundred pounds. On arrival at the London Docks, where im- 
mense bonded warehouses extend as far as the eye can reach, unshipment takes place among some hundreds of other similar imports. Here it remains until the duty demanded by the Custom House officer is paid. The period of bondage may last three years, a small rent being charged for the accommodation. Before releasing it from bond the consignee will unpack the tobacco for the purpose of ascertaining whether it is perfectly sound, or has sustained damage in course of transit ; for it happens sometimes that the material is found to be hardly worth the duty imposed. In this case the consignee is not compelled to release it ; it is left with the Crown officials to make such use of it as they may deem fit. How they dispose of such tobacco is remarked upon in the chapter headed, 'The Use and Abuse of Tobacco.'

In looking over the various sorts of tobacco presented by the tobacconists to the consumer we need not touch upon the delicate ground of 'vested interests.' It will suffice our present purpose if we notice merely that from the same hogshead a selection and classification is made of the leaves according to the shade of colour, and that the lightest coloured (the mild) ones are reserved for less liquoring and pressure than is given to the darker coloured leaves. 'Returns,' for example, is the product of the lightest leaves and less pressure. A large quantity of water used in the process of liquoring has the effect of darkening the colour and giving strength to the flavour of the tobacco. By extreme watering and pressure is produced the kind so dear to the sailor called 'pigtail,' as well as the less pungent 'sag,' of which there are two sorts, fine and common, the difference consisting of the fineness or coarseness of the shreds into which the leaf is cut. These and many other odd circumstances in the manufacture give the different degrees of strength and flavour sought for by the varying tastes of smokers. 
In the opinion of experienced smokers a new cigar is never good; like wine, the weed requires age to bring it to perfection-the highly prized excellences, a mild, cool aromatic smoke. Curiously enough, the marks of a mite on the outer leaf are the true signs of matured years, when the cigar is fitted to regale the jaded senses and dispose the most obdurate of men to relax into sociality. But these seductive touches by an invisible hand are well known to the manufacturer, and are sometimes artificially produced by means of acid. Fancy or experience has suggested different kinds of cigars for different seasons of the year, or climates. The Havana is thought by connoisseurs.to be the most agreeable for summer or hot countries, and for winter or cold climates a principe is preferred; while the thoughtful and imaginative are assured that there is no leaf like the Manila. And as regards the Manila there is something to warrant the suggestion. The tobacco of Luzon when mixed with that of the Gapanian plantation is considered to make the very perfection of all cheroots. Its excellences consist in a delicate flavour combined with a slightly soporific quality: properties which render it so pleasantly alluring to the imaginative, and which to some smokers suggest the use of opium in its preparation; this, however, is not so; to the climate and soil alone are due the grateful pleasures of this most solacing smoke. There are three different and distinct growths of the tobacco-plant in the Philippines. A strong, aromatic tobacco is grown in great abundance in the province of Cagayan in the island of Luzon, and the district of Gapan in Pampanga produces a leaf of a very mild and agreeable flavour, while from Bisayas a tobacco much inferior to either is raised. In the manufacture of the poorer kind it is a common practise to use a leaf of the best as an envelope wrapped round, in order to impart to it a better 
appearance. From the first planting of tobacco in the Philippines until July, I88I, the entire industry had been in the hands of the Spanish Government, who visited illicit production with severe pains and penalties. Yet, notwithstanding the vigilance of the mounted police who scoured the country districts to strike terror into the lawless, the natives living far up the mountain glens of Ylocos and Pangasinan, though leading the roving life of huntsmen, contrived to cultivate patches of the tobacco-plant, for which they always found a ready sale to the traders who at the proper season visited the neighbourhood.

Since the monopoly was abolished, private enterprise, stirred by the wholesome stimulus of competition, has developed and improved the tobacco industry very considerably, with the help of large numbers of diligent hard-toiling Chinamen. This important branch of commerce in Manila provides employment for twenty thousand women and sixteen thousand men. The men are employed almost wholly in making cigarillos for Home consumption; while to the women is allotted the more important task of cheroot-making for exportation. Here the great factories are situated, each of which affords accommodation for about a thousand workpeople. The men and women work in separate factories; those for the women are divided into long rooms along the whole length of which are ranged low tables. At each table a dozen young women are seated, presided over by an old woman whose duty is to try and maintain order among the girls and see that there is no waste of material, for to each table a certain quantity of tobacco is weighed out. If the proportionate number of cigars is not produced, woe betide the hapless one : on pay day deductions for waste come into the reckoning.

But however interesting the workers and their work may 
be, the visitor seldom cares to prolong his stay where a thousand voices are in full chatter and stone hammers are incessantly beating, on wooden tables, leaves of the plant in readiness for the lissom fingers of the girls who roll them up into cheroot form. These women of weeds earn good wages-from eight to ten dollars a month-which amply suffices to get them all the comforts they need and leave a fair margin for dress, of which they are as proud, if not as prodigal, as the gayest of their European sisters. A novel use for cigars was found in the Philippines some yearsago. Copper money being very scarce, quite inadequate to the daily requirements, cigars were passed from one person to another in lieu of coin, to the small satisfaction of the one in whose hands they had from friction become unsaleable.

It is noteworthy that even tobacco-leaves, the avowed destroyers of insect life, should themselves be the prey of some form of the ubiquitous microbe. Besides the mite just mentioned that speckles the outer leaf of old cigars, a more ravenous one has been discovered working its will on Indian cigar-leaf. In a recent issue of Indian Museum Notes, Mr. Cote gives an interesting account of the works and ways of an insect that drills tiny round holes in tobaccoleaves, so small indeed that they had escaped observation until the havoc wrought awakened alarm. The pest tunnels its way through the leaf, irrespective of strength or flavour, even the Trichinopoli is not beyond its taste. And it multiplies so rapidly that much valuable leaf is soon rendered worthless for smoking. Its method of working has suggested the name of weevil. The Indian tobacco industry, therefore, has now to reckon with a new and unscrupulous competitor in the form of the 'cigar weevil.' It would be a boon to long-suffering humanity and a triumph for the bacteriologist if he could manage to set one 
tribe against another of these evil-doers, to their mutual destruction. If they are like living things in the natural world they will have their foes and their struggles for existence. The old lady's belief that microbes have pink eyes and ravenous teeth may not be perfectly accurate, yet judging from their insidious attacks on unsuspecting mortals we are warranted in assuming that they have other very effective means of combat. The spectacle of internecine warfare going on in their little world, as revealed under the microscope, would afford from its novelty an exhibition worth going miles to see.

The tobacco-plant is not now cultivated in England. James the First thought it shameful that so pernicious a plant should be permitted to take root in our rich and fruitful soil, and caused an edict to be issued prohibiting its cultivation within the British Islands. The King's apologists find reason for the prohibition in his Majesty's concern for the interests of the young colony of tobacco planters settled in Virginia. Be this as it may, Adam Smith (Wealth of Nations) on economic grounds condemns the enactment, saying, 'Home cultivation of tobacco has on this account most absurdly been prohibited through the greater part of Europe which necessarily gives a monopoly to the countries where its cultivation is allowed.'

To the impoverished treasury of Charles the Second its importation was made to yield revenue at a rate equivalent to about thirty shillings a pound weight of our present money, and through the agency of his ministers enacted in 'Laws and Regulations concerning Tobacco' ( 15 Car. II. c. 7. 12. Par. II. c. 34.) that, 'Tobacco is not to be planted in England on a forfeiture of 405 . for every rood of ground thus planted.' This restriction however was ' not to extend to the planting of to bacco in Physic Gardens, in 
quantities not exceeding half a pole, and also, on forfeiture of $£$ ro for every rood of ground.' These prohibitory measures remained in force until April 1886, when English farming being in in extremis the Government granted permission to grow the plant in the United Kingdom, under certain precautions and restrictions for the purpose of safe-guarding the revenue. Several land-owners in Kent, Norfolk and Essex, tried their prentice hand in the new husbandry, notably, Messrs James Carter \& Company of Bromley, whose first crop seemed to give fair promise of future success. Their sanguine expectations however were short-lived. What with hampering restrictions on the one hand and our fickle climate on the other, it soon became too apparent that English agriculturists must not look to the Indian weed for the much needed succour. The crops raised proved to be unmarketable. The cultivation of the tobacco-plant in these islands is no longer authorized.

The Home manufacture of cigars from foreign leaf however increased by leaps and bounds, and now affords remunerative employment for many thousands of workpeople in London alone. There are also large tobacco factories in the chief seats of industry and commerce throughout the kingdom. This is due in great measure to the heavy tax levied upon foreign made cigars imported into this country, namely, six shillings on every pound weight-i.e., double the sum charged on tobacco in the leaf. This great difference would seem to afford the unscrupulous an incentive to fabricate spurious high-priced cigars under foreign names. Looked at in this light it may be a question worth the consideration of the Board of Customs whether or not it would be well to lessen the difference between the two rates of duty-to raise the one 
and lower the other-with advantage to both the consumer and the revenue.

Our gossip about the Indian weed may now be brought to a close with a few words about its co-partner, the pipe. For even tobacco-pipes, like all other products of men's ingenuity, awaken interest all the more engrossing when little else remains to tell the story of those who made them and used them. They carry the imagination back to those shadowy palaces of the Incas and Aztecs, where equally shadowy potentates smoked out of pipes made of precious metals, or of highly polished and richly-gilt wood. Pipes indeed, present features highly interesting to a much larger class than to professed ethnologists. The wide region over which they are found, buried in mounds and tumuli extending from the north-west coast of America to the plains of Patagonia, tell us how universal was the habit of smoking on that vast continent; while similarity of structure suggests a common origin. Curious specimens have been found in the States of Indiana, Illinois, Ohio, Iowa, and in the great Mississippi valley, varying from the simplest forms made out of baked clay with a plain cylinder or urn, to others of a class, very uniform in type, cut out of porphyry in a single piece. These latter have a slightly convex base measuring about four inches in length, and one inch broad, with the bowl on the centre. A fine hole pierces the pipe from end to end of the base to the bottom of the bowl, the opposite end being obviously designed for the smoker to hold in the hand. Others are remarkable for a fine display of artistic skill in the carving of birds, mammals, reptiles and human heads, often fanciful and grotesque, but always vigorously expressed. In Mexico elaborately moulded and ornamented pipes have been found, along with others of a type almost identical 
with our common clay pipe. And in British Columbia pipes are occcasionally met with in the possession of the native Indians, moulded and carved by themselves in almost every variety of fantastic form, and with tracery that would do no discredit to modern art. These are for the most part made of blue slate-clay, and have intricate pierced work carried through the tube. In old Indian gravemounds Messrs Squier \& Davis, in the course of their explorations in 1846-7, found pipes cut into the form of human heads, the features on which were singularly truthful and expressive; and what was still more remarkable was their strikingly Mongolian type, a circumstance which lends support to the hypothesis that in the remote past the American continent was peopled from the eastern part of Asia. Some of the pipes found in these mounds represented animals peculiar to the lower latitudes. On one pipe the otter is shown in the attitude of holding a fish in its mouth : on another the heron has seized a fish; the hawk is grasping a small bird, and with its beak is in the act of tearing it to pieces. Almost every bird and animal common to the country is found boldly carved on the pipes of the aborigines of America.

The material for pipes mostly sought after by the natives is the beautiful and easily wrought red sandstone of the Coteau des Prairies. The calumet, which plays an important part in their civil and religious observances, is made from this source, chiefly on account of the legend respecting its origin and the origin of smoking, mentioned in the first chapter. One can hardly help seeing in the handiwork shown in the make of these curious smoking instruments points of contact with the social condition and intelligence of the makers. From the short nostril tube of the Caribs to the feathered peace-pipe of the continental 
tribes is an advancement in the social scale, such as we see in the difference between the hole in the ground for a bowl made by natives of central India, who use a leaf for a tube, and the richly adorned chibouk of the Turk. This view affords us a glimpse of primitive man struggling to adapt his surroundings to his needs, according to the degree of intelligence to which he has attained.

The ordinary pipe so extensively used in England is made from white clay, found chiefly at Purbeck, in Dorsetshire, and Newton Abbot, in Devonshire. But, in recent years, the heath briar-root of France for pipes has come largely into use. Perhaps no material for pipe bowls stands in higher favour than meerschaum-a fine, white clay consisting chiefly of magnesia, silica and water. The best kinds are found in pits in the Crimea and along the peninsula of Heracleati in Asia Minor. It is soft and porous: the finest specimens are almost transparent. When first taken out of the pits it makes lather like soapsuds. The workmen employed in digging it up say that if left for long lying about it forms itself into froth. Thus the foam of the sea of past ages, driven by the winds into sheltered cavities and hollow places of the earth, comes at last to render service to St Nicotine ; and in our meditative moods is brought vividly before the mind the fabled birth of the goddess of love, laughter and beauty. According to the old Greek myth it was just off the coast of Paphos (Cyprus) that Aphrodite arose from amid sea-foam that covered the mutilated body of old, sleepy, Uranus, who in a drowsy moment had rolled down the cliff into the sea. Springing thus into being she was seen by the three daughters of Zeus (the seasons) who carried her to Olympus, and all the gods admired her for her beauty. There are connoisseurs who fancy that the meerschaum pipes coming 
from this region impart to the tobacco a peculiarly delicate flavour. Constantinople is the great mart for the sale of meerschaum, as Vienna is for its manufacture into pipes. The material is so extremely difficult to manipulate that the uncertainty attending its successful manufacture gives a high value to the better kinds. The meerschaum is soaked in water for twenty-four hours and then turned in a lathe. In this process the clay often proves to be too porous, and is on this account rejected: this will happen as many as seven times out of ten. 






$$
9537
$$




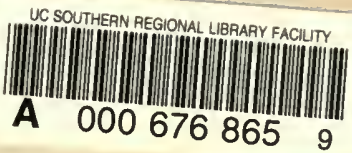


